DOE/ID-22253

Prepared in cooperation with the U.S. Department of Energy

Field Methods, Quality-Assurance, and Data Management Plan for Water-Quality Activities and Water-Level Measurements, Idaho National Laboratory, Idaho

Open-File Report 2021-1004 



\section{Field Methods, Quality-Assurance, and Data Management Plan for Water-Quality Activities and Water-Level Measurements, Idaho National Laboratory, Idaho}

By Roy C. Bartholomay, Neil V. Maimer, Amy J. Wehnke, and Samuel L. Helmuth

DOE/ID-22253

Prepared in cooperation with the U.S. Department of Energy

Open-File Report 2021-1004

U.S Department of the Interior

U.S. Geological Survey 
U.S. Geological Survey, Reston, Virginia: 2021

For more information on the USGS-the Federal source for science about the Earth, its natural and living resources, natural hazards, and the environment-visit https://www.usgs.gov/ or call 1-888-ASK-USGS (1-888-275-8747).

For an overview of USGS information products, including maps, imagery, and publications, visit https:/store.usgs.gov.

Any use of trade, firm, or product names is for descriptive purposes only and does not imply endorsement by the U.S. Government.

Although this information product, for the most part, is in the public domain, it also may contain copyrighted materials as noted in the text. Permission to reproduce copyrighted items must be secured from the copyright owner.

Suggested citation:

Bartholomay, R.C., Maimer, N.V., Wehnke, A.J., and Helmuth, S.L., 2021, Field methods, qualityassurance, and data management plan for water-quality activities and water-level measurements, Idaho National Laboratory, Idaho: U.S. Geological Survey Open-File Report 2021-1004, 76 p., https://doi.org/10.3133/ofr20211004.

ISSN 2331-1258 (online) 


\section{Acknowledgments}

The U.S. Department of Energy provides funding for the USGS Idaho National Laboratory Project and their Radiological and Environmental Sciences Laboratory under the leadership of Anita Bhatt, Director, provides radiochemical analyses. Special thanks to Austin Baldwin and Linda Debrewer of the U.S. Geological Survey for technical review of this manuscript. 


\section{Contents}

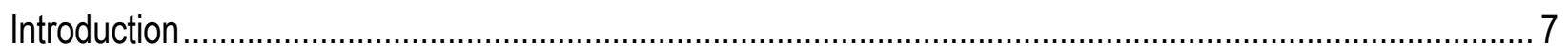

Purposes of and Responsibility for Maintaining the Quality-Assurance Plan ........................................ 7

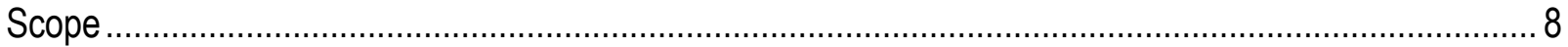

Description of Water-Quality Monitoring Networks ......................................................................... 8

Description of Water-Level Monitoring Networks........................................................................... 10

Field Methods for Water Quality Activities ................................................................................... 10

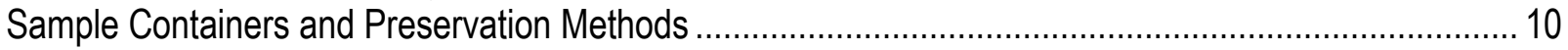

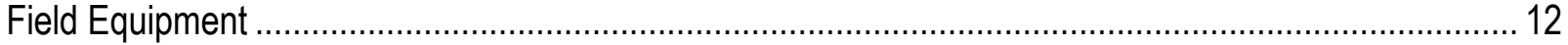

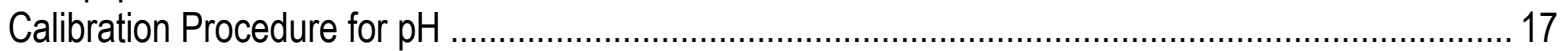

Calibration Procedure for Specific Conductance .................................................................... 17

Calibration Procedure for Dissolved Oxygen ......................................................................... 18

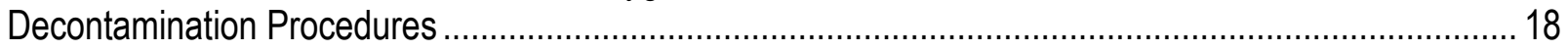

Sample Collection ......................................................................................................... 19

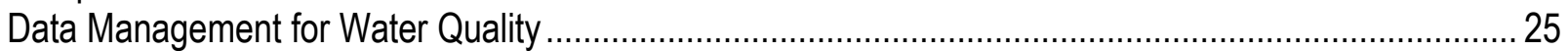

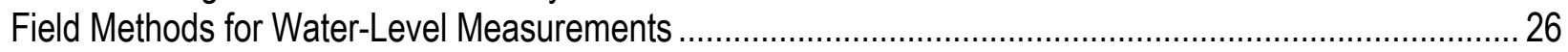

Calibration of Electric Tapes ................................................................................................... 26

Collection Procedures for Water Levels ................................................................................ 26

Calibration and Collection Procedures of Submersible Pressure Transducer and Data Loggers.............. 31

Calibration and Collection Procedures for Multilevel Pressure Measurements ....................................... 32

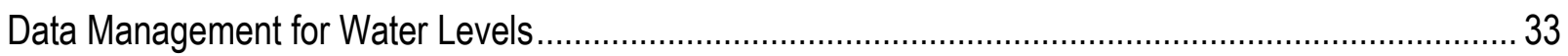

Quality Assurance for Water Quality Activities ................................................................................. 34

Analytical Methods and Quality-Control Samples........................................................................ 35

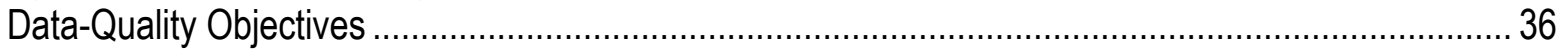

Review of Analyses ............................................................................................................... 36

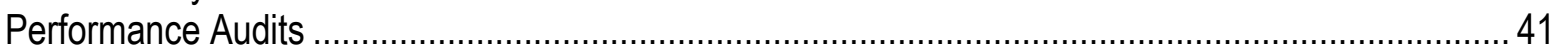

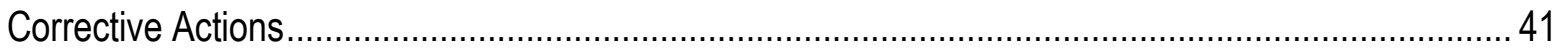

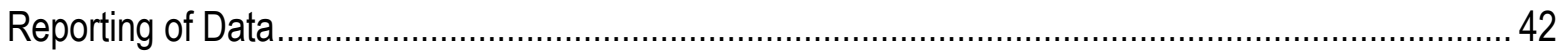

Quality Assurance for Water-Level Measurements...................................................................... 42

Training Requirements and Site Safety ................................................................................ 42

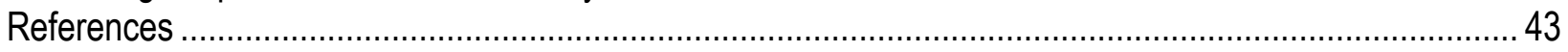

Appendix 1. Field Schedule Showing Well and Pump Information and Sampling Schedules for Selected

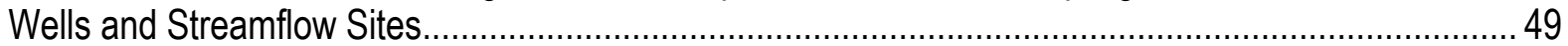

Codes for Types of Analyses (Number of Bottles Needed in Parenthesis) ..........................................52

Appendix 2. Water-Level Measurement Schedule........................................................................ 55

Appendix 3. Data-Quality Objectives for Routine Water Samples Analyzed by the National Water Quality

Laboratory

Appendix 4. Data-Quality Objectives for Radionuclides in Water Samples Analyzed by the Radiological and

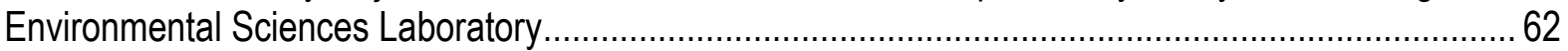

Appendix 5. Data-Quality Objectives for Water Samples Analyzed by GEL Laboratories, LLC, TestAmerica

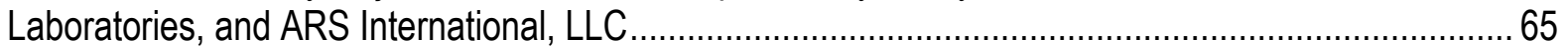

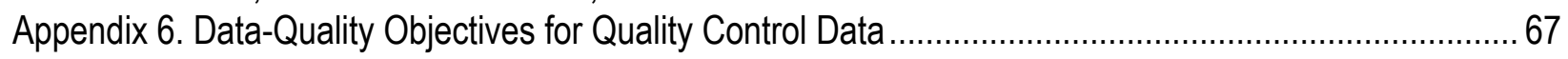

Appendix 7. Inventory of Water-Quality and Water Level Field Equipment .............................................68

Appendix 8. Auditor's Checklist for Quality Assurance Field Audits.......................................................6 69

Appendix 9. Emails Listing the Decision Process for Calibration of Tapes Decision ................................... 72 


\section{Figures}

Figure 1. Sample Personal Computer Field Form sheet. …….......................................................13

Figure 2. Sheet from instrument calibration logbook .................................................................... 16

Figure 3. Label attached to each sample bottle. .......................................................................... 17

Figure 4. Analytical services request form for the National Water Quality Laboratory. .............................21

Figure 5. Sample record sheet for the Radiological and Environmental Sciences Laboratory ................... 22

Figure 6. Sample request and chain-of-custody record for GEL Laboratories, LLC, and TestAmerica

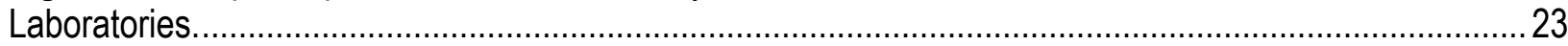

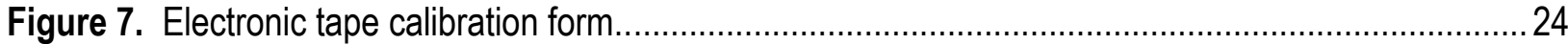

Figure 8. Sample water level field sheet. .................................................................................. 28

Figure 9. Field sheet for multilevel pressure and temperature measurements......................................... 32

\section{Tables}

Table 1. Containers and preservatives used for water samples, U.S. Geological Survey Idaho National Laboratory and vicinity

Table 2. Maximum contaminant levels of types of radioactivity and selected radionuclides in water..........37 Table 3. Maximum contaminant levels, secondary maximum contaminant levels, and reporting levels of selected trace elements in water.

Table 4. Maximum contaminant levels, secondary maximum contaminant levels, and reporting levels of selected common ions in water.

Table 5. Maximum contaminant levels and reporting levels of selected nutrients in water.

Table 6. Maximum contaminant levels and minimum reporting levels of selected volatile organic compounds in water. 


\section{Conversion Factors}

U.S. customary units to International System of Units

\begin{tabular}{lcl}
\hline \multicolumn{1}{c}{ Multiply } & By & To obtain \\
\hline inch (in.) & 2.54 & centimeter $(\mathrm{cm})$ \\
inch (in.) & 25.4 & millimeter $(\mathrm{mm})$ \\
foot (ft) & 0.3048 & meter $(\mathrm{m})$ \\
\hline \multicolumn{3}{c}{ Flow rate } \\
\hline gallon per minute $(\mathrm{gal} / \mathrm{min})$ & 0.06309 & liter per second $(\mathrm{L} / \mathrm{s})$ \\
\hline picocurie per liter $(\mathrm{pCi} / \mathrm{L})$ & Radioactivity & becquerel per liter $(\mathrm{Bq} / \mathrm{L})$ \\
\hline Temperature in degrees Celsius $\left({ }^{\circ} \mathrm{C}\right)$ may be converted to degrees Fahrenheit $\left({ }^{\circ} \mathrm{F}\right)$ as follows: \\
${ }^{\circ} \mathrm{F}=\left(1.8 \times{ }^{\circ} \mathrm{C}\right)+32$ & \\
Temperature in degrees Fahrenheit $\left({ }^{\circ} \mathrm{F}\right)$ may be converted to degrees Celsius $\left({ }^{\circ} \mathrm{C}\right)$ as follows:
\end{tabular}

\section{Datums}

Vertical coordinate information is referenced to the North American Vertical Datum of 1988 (NAVD 88).

Horizontal coordinate information is referenced to the North American Datum of 1983 (NAD 83).

\section{Supplemental Information}

Specific conductance is given in microsiemens per centimeter at 25 degrees Celsius $\left(\mu \mathrm{S} / \mathrm{cm}\right.$ at $\left.25^{\circ} \mathrm{C}\right)$.

Concentrations of chemical constituents in water are given in either milligrams per liter $(\mathrm{mg} / \mathrm{L})$ or micrograms per liter $(\mu \mathrm{g} / \mathrm{L})$.

Activities for radioactive constituents in water are given in picocuries per liter ( $\mathrm{pCi} / \mathrm{L})$.

\section{Abbreviations}

$\begin{array}{ll}\text { DOD } & \text { U.S. Department of Defense } \\ \text { DOE } & \text { U.S. Department of Energy } \\ \text { EPA } & \text { U.S. Environmental Protection Agency } \\ \text { ESRPA } & \text { eastern Snake River Plain aquifer } \\ \text { INL } & \text { Idaho Natinoal Laboratory } \\ \text { MLMS } & \text { multi-level monitoring sampling systems } \\ \text { NAD 83 } & \text { North American Datum of 1983 } \\ \text { NAVD 88 } & \text { North American Vertical Datum of 1988 } \\ \text { NGVD 29 } & \text { National Geodetic Vertical Datum of 1929 } \\ \text { NRF } & \text { Naval Reactors Facility } \\ \text { PCFF } & \text { personal computer field form } \\ \text { ppm } & \text { parts per million } \\ \text { QAP } & \text { quality assurance plan } \\ \text { RESL } & \text { U.S. Department of Energy's Radiological and Environmental Sciences Laboratory } \\ \text { RSIL } & \text { U.S. Geological Survey's Reston Stable Isotope Laboratory } \\ \text { USGS } & \text { U.S. Geological Survey } \\ \text { VOC } & \text { volatile organic compound }\end{array}$




\title{
Field Methods, Quality-Assurance, and Data Management Plan for Water-Quality Activities and Water-Level Measurements, Idaho National Laboratory, Idaho
}

\author{
By Roy C. Bartholomay, Neil V. Maimer, Amy J. Wehnke, and Samuel L. Helmuth
}

\section{Introduction}

Water-quality activities and water-level measurements conducted by the U.S. Geological Survey (USGS) Idaho National Laboratory (INL) Project Office coincide with the USGS mission of appraising the quantity and quality of the Nation's water resources. The activities are conducted in cooperation with the U.S. Department of Energy's (DOE) Idaho Operations Office. Results of water-quality and hydraulic head investigations are presented in various USGS publications or in refereed scientific journals, and the data are stored in the National Water Information System (NWIS) database. The results of the studies are used by researchers, regulatory and managerial agencies, and civic groups.

In its broadest sense, "quality assurance" refers to doing the job right the first time. It includes the functions of planning for products, review and acceptance of the products, and an audit designed to evaluate the system that produces the products. Quality control and quality assurance differ in that quality control ensures that things are done correctly given the "state-ofthe-art" technology, and quality assurance ensures that quality control is maintained within specified limits.

\section{Purposes of and Responsibility for Maintaining the Quality-Assurance Plan}

The purposes of the Quality-Assurance Plan (QAP) for water-quality and water-level activities performed by the USGS INL Project Office are to maintain the quality of technical products and to provide formal standardization, documentation, and review of the activities that lead to these products. The principles of this plan are as follows:

1. Water-quality and water-level programs will be planned in a technically sound manner, and activities will be monitored for compliance with stated objectives and approaches. The objectives and approaches are defined in an annual project task plan.

2. Field, laboratory, and office activities will be performed in a conscientious and professional manner in accordance with specified USGS Water Mission Area practices and procedures by qualified and experienced employees who are well trained and supervised. If USGS practices and procedures are unspecified or inadequate, the procedures used and the assessment of data quality are documented. 
3. All water-quality and water-level activities will be reviewed for completeness, reliability, credibility, and conformance with specified standards and guidelines.

4. A record of actions will be kept to document the activities and the assigned responsibilities.

5. Remedial action will be taken to correct activities that are deficient.

The Chief of the USGS INL Project Office has overall responsibility for maintaining this QAP. However, the principal investigator for geochemistry and the lead personnel for the waterquality and water-level monitoring networks are directly responsible for the day-to-day maintenance of the QAP. The QAP will be formally revised and reprinted as necessary; changes that take place in the interim will be communicated by memoranda to project-office personnel on an as-needed basis, and copies of those memoranda will be stored in the USGS INL Project Office quality-assurance file and on the INL Project Office server.

\section{Scope}

The QAP for the water-quality activities and water-level measurements of the USGS INL Project Office defines procedures and tasks performed by project-office personnel that ensure the reliability of water-quality and water-level measurement data. Most of the principles of the plan have been in effect during past and current operations, but the QAP provides a method for formalizing and communicating the plan to all employees of the project office and to users of the hydrologic data and interpretive reports. The QAP was implemented in 1989 and revised in 1992, 1996 (Mann, 1996), 2003 (Bartholomay and others, 2003), 2008 (Knobel and others, 2008), and 2014 (Bartholomay and others, 2014). This version of the QAP incorporates the revisions made to the water-quality and water-level monitoring programs since 2014 and adds the processes and procedures that the INL Project Office uses to manage their water quality and water level data. A comprehensive list of references containing procedures used in data collection is given in the "References" section at the end of this report. Tasks not described by the references owing to field conditions are detailed in the following sections or in the Idaho Water Science Center Quality-Assurance Plan for Water-Quality Activities (Christopher Mebane and Rhonda J. Weakland, U.S. Geological Survey, written commun., 2016), the Quality Assurance Plan for Groundwater Activities of the USGS Idaho Water Science Center (Annette M. Campbell and James R. Bartolino, U.S. Geological Survey, written commun., June 2018), or the Idaho Water Science Center Data Management Plan (Annette M. Campbell, U.S. Geological Survey, written commun., January 2015).

Information on water-quality sampling schedules, water-level measurement schedules, data-quality objectives, water-quality field equipment, and field audits are included in appendices $1-8$.

\section{Description of Water-Quality Monitoring Networks} define:

The USGS has maintained a water-quality monitoring program at the INL since 1949 to

1. The quality and availability of water for human consumption,

2. The usability of the water for supporting construction of facilities and for industrial purposes such as cooling systems and diluting concentrated waste streams,

3. The sources of recharge to the eastern Snake River Plain aquifer (ESRPA), 
4. The processes controlling the origin and distribution of contaminants and naturally occurring constituents in the ESRPA,

5. The location and movement of contaminants in the ESRPA that were contained in wastewater discharged at the INL, either to the ESRPA or to the overlying perched groundwater zones, and

6. An early-detection network for contaminants moving past the INL boundaries.

Disposal of contaminants at the INL has taken place through deep disposal wells, shallow infiltration ponds, and disposal ditches.

A large network of about 300 wells has been sampled in the past, and the current routine sampling network consists of 126 wells and 5 surface-water sites (app. 1). Additional monitoring sites will be selected if needed to better document the distribution and migration of contaminants. Most of the 126 wells are open-borehole wells with a screened interval that is open to the aquifer for the entire well depth below the water table. This type of construction is adequate for identifying the time of arrival of contaminant plumes and for delineating the horizontal extent of contaminants; however, it is not conducive to identifying the vertical distribution of contaminants.

In order to better identify the vertical distribution of contaminants in the aquifer, multilevel water-quality sampling, along with pressure and temperature profiling networks, was initiated in 2005. Westbay ${ }^{\mathrm{TM}}$, packer-based, vertical multi-level monitoring sampling systems (MLMS) were installed in Middle 2050A and Middle 2051. Each well was configured so that water samples could be collected at 5 discrete depths (at both wells) and pressure and temperature measurements could be made at 15 and 13 discrete depths, respectively. In 2006, wells USGS 132 and USGS 134 were configured so that water samples could be collected at 6 and 5 discrete depths, respectively, and pressure and temperature measurements could be made at 23 and 20 discrete depths, respectively. In 2007, wells USGS 103 and USGS 133 were configured so that water samples could be collected at 7 and 4 discrete depths, respectively, and pressure and temperature measurements could be made at 23 and 13 discrete depths, respectively. In 2009, wells USGS 105 and USGS 135 were configured so that water samples could be collected at 5 and 4 discrete depths, respectively, and pressure and temperature measurements could be made at 18 and 14 discrete depths, respectively. In 2010, USGS 108 was configured so that water samples could be collected at 5 discrete depths and pressure and temperature measurements could be made at 16 discrete depths. In 2012, USGS 131 A and 137A were configured so that water samples could be collected at four and four discrete depths, respectively, and pressure and temperature measurements could be made at 18 and 14 discrete depths, respectively. In 2019, USGS 149 was configured so that water samples could be collected at 4 discrete depths and pressure and temperature measurements could be made at 12 discrete depths. As with open-borehole construction, the packer-based construction allows for identifying the time of arrival of contaminant plumes and for delineating the horizontal extent of contaminants. Additionally, this type of construction provides the capability for identifying the vertical distribution of contaminants, pressure, and temperature.

The wells and streams in the INL routine network and in the MLMS network are sampled annually as indicated in appendix 1. Starting in 2020, water sample monitoring no longer occurred at USGS 134 and 135; however, pressure and temperature measurements were still collected. The Radioactive Waste Management Complex Production Well is sampled for volatile organic compounds (VOCs) on a monthly basis. In addition to the routine sampling indicated in 
appendix 1, some wells may be sampled periodically for other constituents, including iodine129, trace metals, VOCs, dissolved gases, isotopes, and compounds used for age dating.

In addition to the 131 groundwater and surface-water sites currently sampled annually for the routine-monitoring network and the 10 sites sampled for vertical definition of contaminants in the aquifer, the USGS INL Project Office staff collects water samples from 14 wells near the Naval Reactors Facility (NRF) on a semi-annual basis (app. 1). The purpose of this datacollection program is to provide the DOE's Pittsburgh Naval Reactors Office, Idaho Branch Office, with chemical and radiochemical data to evaluate the effect of NRF activities on the water quality of the ESRPA.

\section{Description of Water-Level Monitoring Networks}

The USGS has maintained a water-level monitoring program at the INL since 1949 to systematically measure water levels to provide long-term information on the ESRPA for groundwater recharge, discharge, movement, and storage. The USGS INL Project Office currently (2020) monitors 193 open boreholes (29 perched and 164 aquifer) (app. 2) and 12 MLMS that includes 190 pressure ports.

Collection of water-level data are obtained manually by use of electronic (e)-tapes and continuous data loggers. Water levels are collected monthly, quarterly, tri-annually, semiannually or annually depending on historical data, research needs and changes in the hydrograph. Within the USGS water level monitoring network, there currently are nine continuous data loggers, two of which are equipped to transmit real-time continuous data.

USGS began installing MLMS in 2005 to provide monitoring of the vertical distribution of pressure gradients in the aquifer. Additionally, six wells (USGS 30, 139, 142, 145, HWY 1, and NRF-15) have been completed with piezometer nests at different levels of the aquifer to better define vertical distribution. The 12 MLMS were equipped with multiple measurement ports (8-23) to help improve the USGS INL groundwater modeling studies. Pressure profiles are collected either quarterly or annually depending on the location of the well and the need for information.

\section{Field Methods for Water Quality Activities}

Sample containers, sample preservation methods, field equipment, and well-head decontamination and sample-collection procedures are crucial components in assuring that dataquality objectives are achieved at the field level. Equally important are the analytical methods and the quality-control and quality-assurance activities exercised by the laboratories that analyze the samples.

\section{Sample Containers and Preservation Methods}

Sample containers and preservation methods differ depending on the chemistry of the constituents being analyzed. Samples analyzed by the USGS National Water Quality Laboratory (NWQL) are containerized and preserved in accordance with laboratory requirements that are summarized by the USGS (variously dated, chapter A5). Containers and chemical preservatives are supplied by the NWQL, where they undergo rigorous quality control to ensure that they are free of contamination (Pritt, 1989, p. 75). Samples analyzed by the U.S. Department of Energy's Radiological and Environmental Sciences Laboratory (RESL) are containerized and preserved in accordance with requirements specified by the laboratory's Analytical Chemistry Measurements 
Team; changes in procedures are documented in writing. Samples analyzed as part of the USGS NRF sample program are containerized and preserved in accordance with requirements specified by TestAmerica Laboratories (2013) and GEL Laboratories, LLC (2015). Containers and preservatives for selected constituents are summarized in table 1.

Table 1. Containers and preservatives used for water samples, U.S. Geological Survey Idaho National Laboratory and vicinity.

[Type of constituent: VOCs, volatile organic compounds; C, carbon; H, hydrogen; O, oxygen; CFC, chlorofluorocarbon; $\mathrm{HNO}_{3}$, nitric acid; $\mathrm{HCl}$, hydrochloric acid; $\mathrm{H}_{2} \mathrm{SO}_{4}$, sulfuric acid; $\mathrm{KOH}$, potassium hydroxide; ${ }^{\circ} \mathrm{C}$, degrees Celsius. Analyzing laboratory: NWQL, U. S. Geological Survey's National Water Quality Laboratory; GEL, General Engineering Laboratory; RESL, U.S. Department of Energy's Radiological and Environmental Sciences Laboratory; RSIL, U.S. Geological Survey's Reston Stable Isotope Laboratory; ARS-ARS International, LLC; Test America-Eurofins Test America Laboratory; PRIME, Purdue Rare Isotope Measurement Laboratory.

Abbreviations: $\mathrm{mL}$, milliliter; L, liter; $\mathrm{N}$, normal]

\begin{tabular}{|c|c|c|c|c|c|c|}
\hline \multirow{2}{*}{$\begin{array}{c}\text { Type of } \\
\text { constituent }\end{array}$} & \multicolumn{2}{|c|}{ Container } & \multicolumn{2}{|c|}{ Preservative } & \multirow{2}{*}{ Other treatment } & \multirow{2}{*}{$\begin{array}{l}\text { Analyzing } \\
\text { laboratory }\end{array}$} \\
\hline & Type & Size & Type & Volume & & \\
\hline Anions, dissolved & Polyethylene & $250 \mathrm{~mL}$ & None & None & Filter & NWQL \\
\hline Anions, dissolved & Polyethylene & $1 \mathrm{~L}$ & None & None & Filter & GEL \\
\hline Cations, dissolved & $\begin{array}{l}\text { Polyethylene, acid } \\
\text { rinsed }\end{array}$ & $250 \mathrm{~mL}$ & $\mathrm{HNO}_{3}$ & $2 \mathrm{~mL}$ & Filter & NWQL \\
\hline Cations, total & $\begin{array}{l}\text { Polyethylene, acid } \\
\text { rinsed }\end{array}$ & $500 \mathrm{~mL}$ & $\mathrm{HNO}_{3}$ & $2 \mathrm{~mL}$ & None & GEL \\
\hline Metals, dissolved & $\begin{array}{l}\text { Polyethylene, acid } \\
\text { rinsed }\end{array}$ & $250 \mathrm{~mL}$ & $\mathrm{HNO}_{3}$ & $2 \mathrm{~mL}$ & Filter & NWQL \\
\hline Metals, total & $\begin{array}{l}\text { Polyethylene, acid } \\
\text { rinsed }\end{array}$ & $250 \mathrm{~mL}$ & $\mathrm{HNO}_{3}$ & $2 \mathrm{~mL}$ & None & NWQL \\
\hline Metals, dissolved & $\begin{array}{l}\text { Polyethylene, acid } \\
\text { rinsed }\end{array}$ & $500 \mathrm{~mL}$ & $\mathrm{HNO}_{3}$ & $2 \mathrm{~mL}$ & Filter & GEL \\
\hline Metals, total & $\begin{array}{l}\text { Polyethylene, acid } \\
\text { rinsed }\end{array}$ & $500 \mathrm{~mL}$ & $\mathrm{HNO}_{3}$ & $2 \mathrm{~mL}$ & None & GEL \\
\hline $\begin{array}{l}\text { Mercury, } \\
\text { dissolved }\end{array}$ & Glass, acid rinsed & $250 \mathrm{~mL}$ & $6 \mathrm{~N} \mathrm{HCl}$ & $2 \mathrm{~mL}$ & Filter & NWQL \\
\hline Mercury, total & Glass, acid rinsed & $250 \mathrm{~mL}$ & $6 \mathrm{~N} \mathrm{HCl}$ & $2 \mathrm{~mL}$ & None & NWQL \\
\hline $\begin{array}{l}\text { Chromium, } \\
\text { dissolved }\end{array}$ & $\begin{array}{l}\text { Polyethylene, acid } \\
\text { rinsed }\end{array}$ & $250 \mathrm{~mL}$ & $\mathrm{HNO}_{3}$ & $2 \mathrm{~mL}$ & Filter & NWQL \\
\hline $\begin{array}{l}\text { Nutrients, } \\
\text { dissolved }\end{array}$ & $\begin{array}{l}\text { Polyethylene, } \\
\text { brown }\end{array}$ & $125 \mathrm{~mL}$ & None & None & Filter, chill, $4^{\circ} \mathrm{C}$ & NWQL \\
\hline $\begin{array}{l}\text { Nutrients, } \\
\text { dissolved }\end{array}$ & $\begin{array}{l}\text { Polyethylene, acid } \\
\text { rinsed }\end{array}$ & $125 \mathrm{~mL}$ & $\mathrm{H}_{2} \mathrm{SO}_{4}$ & $2 \mathrm{~mL}$ & Chill, $4^{\circ} \mathrm{C}$ & GEL \\
\hline Nutrients, total & $\begin{array}{l}\text { Polyethylene, acid } \\
\text { rinsed }\end{array}$ & $125 \mathrm{~mL}$ & $\mathrm{H}_{2} \mathrm{SO}_{4}$ & $2 \mathrm{~mL}$ & Chill, $4^{\circ} \mathrm{C}$ & GEL \\
\hline VOCs & Glass, baked & $40 \mathrm{~mL}(3)$ & None & None & Chill, $4^{\circ} \mathrm{C}$ & NWQL \\
\hline VOCs & Glass & $40 \mathrm{~mL}$ (3) & $\mathrm{C}_{6} \mathrm{H}_{8} \mathrm{O}_{6}$ & $25 \mathrm{mg}$ & Chill, $4^{\circ} \mathrm{C}$ & GEL \\
\hline Semi-VOCs & Glass, baked & $1 \mathrm{~L}(2)$ & $\mathrm{HCl}$ & $4 \mathrm{~mL} / \mathrm{bottle}$ & Chill, $4^{\circ} \mathrm{C}$ & Test America \\
\hline $\begin{array}{l}\text { Gross alpha/beta- } \\
\text { particle }\end{array}$ & $\begin{array}{l}\text { Polyethylene, acid } \\
\text { rinsed }\end{array}$ & $500 \mathrm{~mL}$ & $\mathrm{HNO}_{3}$ & $2 \mathrm{~mL}$ & None & RESL \\
\hline Nickel-63 & $\begin{array}{l}\text { Polyethylene, acid } \\
\text { rinsed }\end{array}$ & $2 \mathrm{~L}$ & $\mathrm{HNO}_{3}$ & $4 \mathrm{~mL}$ & None & GEL \\
\hline \multirow[t]{2}{*}{ Strontium-90 } & $\begin{array}{l}\text { Polyethylene, acid } \\
\text { rinsed }\end{array}$ & $2 \mathrm{~L}$ & $\mathrm{HNO}_{3}$ & $4 \mathrm{~mL}$ & None & GEL \\
\hline & Polyethylene, acid & $500 \mathrm{~mL}$ & $\mathrm{HNO}_{3}$ & $2 \mathrm{~mL}$ & None & RESL \\
\hline
\end{tabular}




\begin{tabular}{|c|c|c|c|c|c|c|}
\hline \multirow{2}{*}{$\begin{array}{c}\text { Type of } \\
\text { constituent }\end{array}$} & \multicolumn{2}{|c|}{ Container } & \multicolumn{2}{|c|}{ Preservative } & \multirow{2}{*}{ Other treatment } & \multirow{2}{*}{$\begin{array}{l}\text { Analyzing } \\
\text { laboratory }\end{array}$} \\
\hline & Type & Size & Type & Volume & & \\
\hline \multirow[t]{2}{*}{$\begin{array}{l}\text { Gamma } \\
\text { spectroscopy }\end{array}$} & $\begin{array}{l}\text { Polyethylene, acid } \\
\text { rinsed }\end{array}$ & $2 \mathrm{~L}$ & $\mathrm{HNO}_{3}$ & $4 \mathrm{~mL}$ & None & GEL \\
\hline & Polyethylene, acid & $500 \mathrm{~mL}$ & $\mathrm{HNO}_{3}$ & $2 \mathrm{~mL}$ & None & RESL \\
\hline \multirow[t]{3}{*}{ Tritium } & Polyethylene & $500 \mathrm{~mL}$ & None & None & None & NWQL \\
\hline & Polyethylene & $500 \mathrm{~mL}$ & None & None & None & RESL \\
\hline & Polyethylene & $1 \mathrm{~L}$ & None & None & None & ARS \\
\hline Transuranics & $\begin{array}{l}\text { Polyethylene, acid } \\
\text { rinsed }\end{array}$ & $1 \mathrm{~L}$ & $\mathrm{HNO}_{3}$ & $4 \mathrm{~mL}$ & None & RESL \\
\hline Isotopic uranium & $\begin{array}{l}\text { Polyethylene, acid } \\
\text { rinse }\end{array}$ & $1 \mathrm{~L}$ & $\mathrm{HNO}_{3}$ & $4 \mathrm{~mL}$ & Filter & Test America \\
\hline $\begin{array}{l}\mathrm{O}-18 / \mathrm{O}-16 \text { and } \mathrm{H}- \\
2 / \mathrm{H}-1\end{array}$ & $\begin{array}{l}\text { Glass, with } \\
\text { polyseal cap }\end{array}$ & $60 \mathrm{~mL}$ & None & None & None & RSIL \\
\hline $\mathrm{C}-13 / \mathrm{C}-12$ & $\begin{array}{l}\text { Glass, with plastic } \\
\text { coating, } \\
\text { polyseal cap }\end{array}$ & $1 \mathrm{~L}$ & None & None & None & RSIL \\
\hline Dissolved gases & $\begin{array}{l}\text { Glass, with rubber } \\
\text { stopper }\end{array}$ & $150 \mathrm{~mL}$ & None & None & $\begin{array}{l}\text { Relieve } \\
\text { pressure } \\
\text { w/needle }\end{array}$ & $\begin{array}{l}\text { Reston CFC } \\
\text { Laboratory }\end{array}$ \\
\hline CFC-Age dating & $\begin{array}{l}\text { Glass, with white } \\
\text { plastic caps, } \\
\text { aluminum foil } \\
\text { liner }\end{array}$ & $125 \mathrm{~mL}$ & None & None & None & $\begin{array}{l}\text { Reston CFC } \\
\text { Laboratory }\end{array}$ \\
\hline Iodine-129 & $\begin{array}{l}\text { Polyethylene with } \\
\text { polyseal cap }\end{array}$ & $1 \mathrm{~L}$ & $\begin{array}{r}\mathrm{KOH} \text { and } \\
\text { sulfuro } \\
\text { us acid }\end{array}$ & None & Filter & PRIME Lab \\
\hline
\end{tabular}

\section{Field Equipment}

Analytical and other associated equipment used in the field include $\mathrm{pH}$ meters, thermometers, multiparameter instruments, titrators for alkalinity measurements, peristaltic pumps, in-line disposable filter capsules with a 0.45 -micron filter that is certified to be analyte free, and associated glassware. The analytical equipment is housed and usually operated in mobile field laboratories. The purpose of the mobile laboratories is threefold: (1) they provide a relatively clean area to measure field parameters while minimizing the potential for contamination or degradation of the samples from the wind, dust, rain, snow, and sunlight; (2) they are used as storage for sample and shipping containers, chemical reagents and preservatives, analytical instrumentation, and deionized water used for decontaminating equipment in the field; and (3) they provide a place where samples can be containerized, preserved, and placed in a secured refrigerator or transportation container within minutes after withdrawal from a well or stream.

The multiparameter instruments used to measure field water-quality parameters, such as $\mathrm{pH}$, specific conductance, and dissolved oxygen are maintained and calibrated in accordance with procedures specified by the instrument manufacturer; calibration data are recorded in the water-quality personal computer field form (PCFF) (fig.1) and in the instrument calibration logbook (fig. 2). Forms are reviewed twice a year by the INL Project Chief. Changes to equipment-for example, changing batteries or the dissolved oxygen membrane - is recorded in the instrument calibration logbook. An inventory of field equipment is given in appendix 7 . 
Station Name 02N 31E 35DCC1 USGS 1

Sample Date 10/01/2019 Mean Sample Time (watch) 10:57 Sample Medium (WG) Groundwater

Sample Purpose (71999)

Project No.GR20YE009HZG500 Project Name INLPO

Sampling Team $\underline{\mathrm{nm}}$

End Time

Sample Type (9) Regular

Purpose of Site Visit (50280):

QC Samples Collected? Team Lead Signature Date

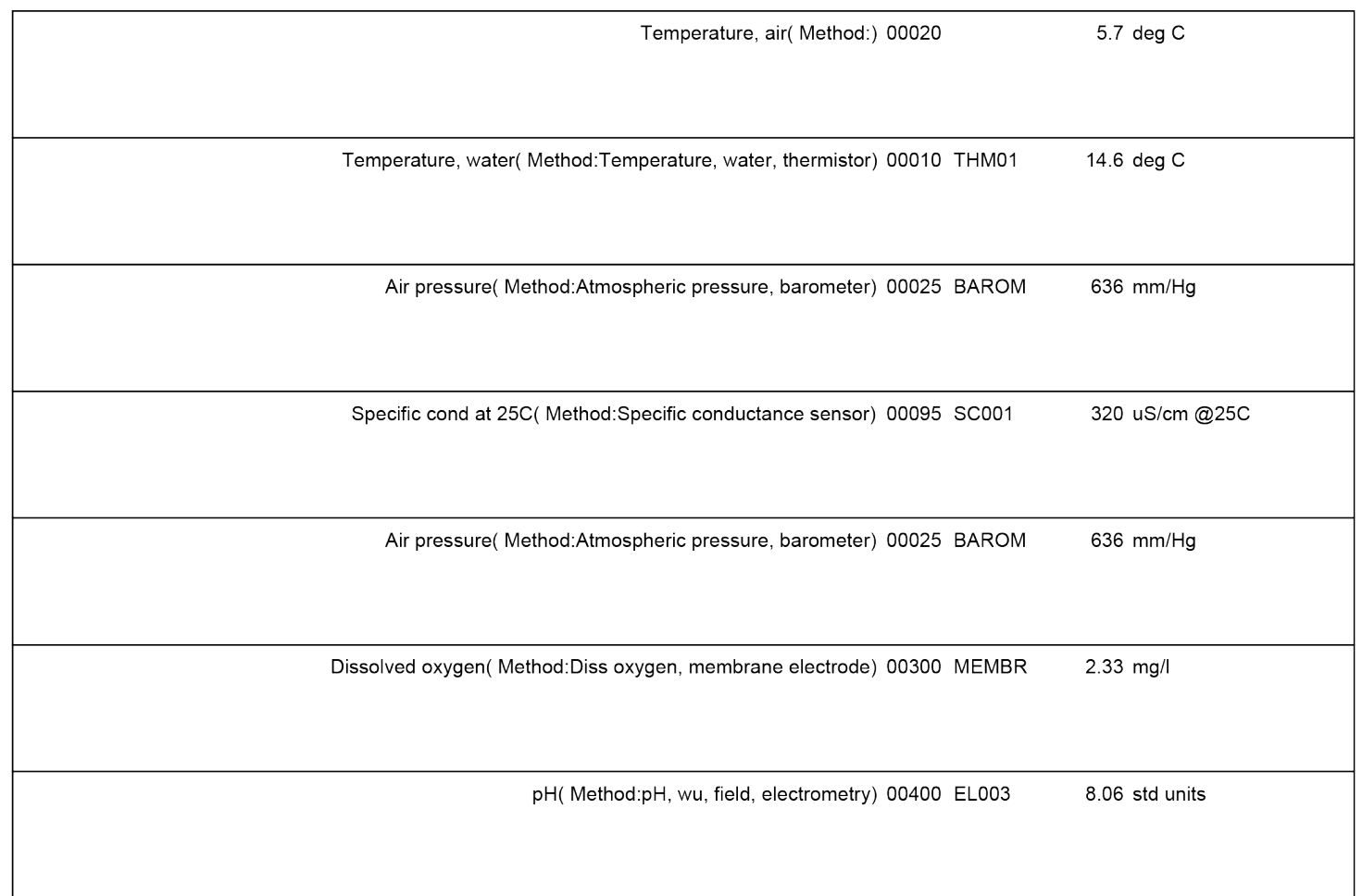

Analysis Status (U) Unrestricted Hydrologic Condition $(X)$ Not applicable Hydrologic Event $(\mathrm{X})$ Not applicable

Sample method (82398) (4040) Submersible pump Sampler Type (84164)

\section{SAMPLING INFORMATION}

Pump/Sampler make/model: Grundfos $5 \mathrm{hp}$

Sampling Condition (72006) sample source (72005)

Figure 1. Sample Personal Computer Field Form sheet. 


\begin{tabular}{|c|c|}
\hline \multicolumn{2}{|c|}{ Depth to set pump from MP $\quad$ (all units in feet) } \\
\hline Distance to top of screen from LSD & \\
\hline MP & \\
\hline dia. factor of well & $\underline{5 "}$ \\
\hline DEPTH TO PUMP FROM MP & \\
\hline DEPTH TO PUMP FROM LSD & \\
\hline
\end{tabular}

Sampling depth(00003/): $\underline{\text { TD } 630 \mathrm{ft}}$
WELL DATA

PURGE VOLUME

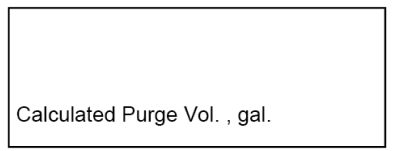

Flow rate, instant.(00059/): $20 \mathrm{gal} / \mathrm{min}$

Time pumped before sampling

(72004) 2 minutes
Calculated pump period

Min Min

FIELD OBSERVATIONS

Sampling point: 1/4" ss sample port, 5 hp sub pump

Water level: 594.51', pump on @ 1032

Control box @ 60 Hz (ccw)

Observers: none

Reference Number: 1910012

Field Sample Comments ( for NWIS, 300 characters max.):

Sch 19 - 3H, Alpha/Beta, Na+, Cr, Cl-, SO4- -, NO3- (5)

\section{QUALITY-CONTROL INFORMATION}

QC sample associated with this info 99111 environmental sample (99111):

Purpose, Topical QC data (99112): info 99112

Replicate-sample type (99105): info 99105

Reference-material or spike source

code no. (99104): info 99104

Reference-material source (99103): info 99103

Blank-solution type (99100): info 99100

Source of blank water (99101): info 99101

Blank-sample type (99102): info 99102

Spike-sample type (99106): info 99106

Spike-solution source (99107): info 99107

Spike-solution volume, $\mathrm{mL}$ (99108): info 99108

Figure 1.-Continued 


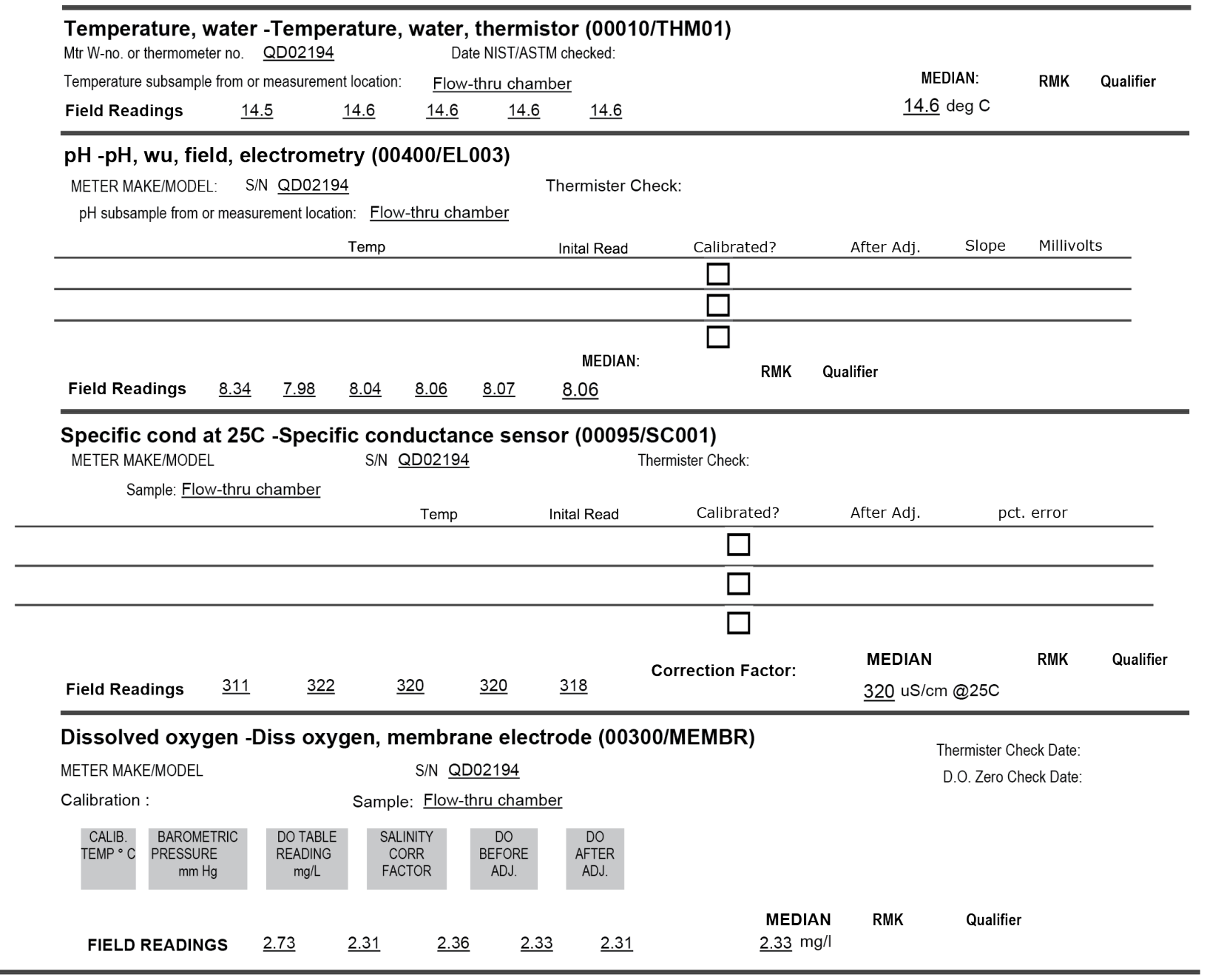

Calibration Notes and Remarks

Figure 1.-Continued 
Date

Employee Name

\section{pH Calibration}

\begin{tabular}{|l|c|l|l|r|r|l|l|}
\hline \multicolumn{1}{|c|}{ Step } & $\begin{array}{c}\text { Buffer } \\
\text { Circle one }\end{array}$ & Lot \# & $\begin{array}{c}\text { Exp. } \\
\text { Date }\end{array}$ & $\begin{array}{c}\text { Buffer } \\
\text { Temp }\end{array}$ & $\begin{array}{c}\text { Initial } \\
\text { Reading }\end{array}$ & $\begin{array}{c}\text { Adjusted } \\
\text { Reading }\end{array}$ & $\begin{array}{c}\text { End of Day } \\
\text { Check Value }\end{array}$ \\
\hline 1 calibrate & 7 & & & ${ }^{\circ} \mathrm{C}$ & & & \\
\hline 2 set slope & 4 or 10 & & & ${ }^{\circ} \mathrm{C}$ & & & \\
\hline 3 check & 10 or 4 & & & ${ }^{\circ} \mathrm{C}$ & & & \\
\hline Special & & & & ${ }^{\circ} \mathrm{C}$ & & & \\
\hline Special & & & & ${ }^{\circ} \mathrm{C}$ & & & \\
\hline
\end{tabular}

Specific Conductance Calibration

\begin{tabular}{|l|l|l|l|l|l|l|}
\hline $\begin{array}{c}\text { Standard } \\
\text { Value }\end{array}$ & Lot \# & $\begin{array}{c}\text { Exp. } \\
\text { Date }\end{array}$ & $\begin{array}{c}\text { Standard } \\
\text { Temp }\end{array}$ & $\begin{array}{l}\text { Initial } \\
\text { Reading }\end{array}$ & $\begin{array}{l}\text { Adjusted } \\
\text { Reading }\end{array}$ & $\begin{array}{l}\text { End of Day } \\
\text { Check Value }\end{array}$ \\
\hline & & & ${ }^{\circ} \mathrm{C}$ & & & \\
\hline & & & ${ }^{\circ} \mathrm{C}$ & & & \\
\hline & & & ${ }^{\circ} \mathrm{C}$ & & & \\
\hline
\end{tabular}

\section{Dissolved Oxygen Calibration}

\section{Method}

$\square$ Air Calibration in Water

$\square$ Air Calibration Chamber in Air

$\square$ Air-Saturated Water

$\square$ Calibration by Winkler Titration

\begin{tabular}{|l|r|}
\hline \multicolumn{1}{|c|}{ Measurement } & Initial \\
\hline Barometric Pressure & ${ }^{\circ}{ }^{\circ} \mathrm{C}$ \\
\hline Temperature & $\mathrm{mg} / \mathrm{L}$ \\
\hline D.O. Saturation or Winkler & $\mathrm{mg} / \mathrm{L}$ \\
\hline Meter reading & $\mathrm{mg} / \mathrm{L}$ \\
\hline Meter adjusted to & +mm-inches $\times 25.4$ \\
\hline
\end{tabular}

\section{Remarks and Repairs}

Figure 2. Sheet from instrument calibration logbook. 


\begin{tabular}{l|l|}
\hline LOCATION $=$ & 1 OF 1 \\
\hline SAMPLER = & SPECCOND = \\
STA TION NAME $=$ & TIME $=$ \\
DATE $=$ & pH $=$ \\
SAMP LE SIZE $=$ & TREATMENT = \\
REF NUMBER $=$ & AIR TEMP $=$ \\
WATER TEMP $=$ & SCHEDULE $=$ \\
SAMPLE TYPE $=$ & \\
\hline
\end{tabular}

Figure 3. Label attached to each sample bottle.

\section{Calibration Procedure for $\mathrm{pH}$}

The INL Project Office personnel calibrates $\mathrm{pH}$ meters each day during which waterquality samples are collected. Calibration of the meter can be performed in the laboratory or at the first well site where water-quality samples are collected that day. The calibration standards are warmed or chilled to a temperature similar to well temperatures measured for the day. The calibration data are recorded in the instrument calibration logbook (fig. 2). If the calibration is done in the laboratory and the meter is then transported to the well site, the meter is checked with a $\mathrm{pH} 7$ buffer prior to sampling if the $\mathrm{pH}$ differs by more than $0.2 \mathrm{pH}$ units from the previous two readings recorded at the site. The meter is recalibrated if the 7 buffer check is off by more than $0.2 \mathrm{pH}$ units. The $\mathrm{pH}$ also is checked for accuracy with a $\mathrm{pH} 7$ buffer before sampling at each subsequent well if the initial readings taken at the new site differ by more than $0.2 \mathrm{pH}$ units from the previous two readings recorded at the site. The measured value of the $\mathrm{pH} 7$ buffer is recorded on the PCFF (fig. 1) for the appropriate site. A pH reading of the $\mathrm{pH} 7$ buffer is taken after sampling the last site of the day for the end-of-day check and recorded in the instrument calibration logbook (fig. 2).

\section{Calibration Procedure for Specific Conductance}

The INL Project Office personnel calibrates specific conductance meters each day during which water-quality samples are collected. Calibration of the meters can be performed in the laboratory or at the first site where water-quality samples are collected that day, but temperature of the standards should be close to what will be measured. The calibration data are recorded in the instrument calibration logbook (fig. 2). If the calibration is done in the laboratory and the meter is then transported to the site, the specific conductance meter is checked with the appropriate buffer prior to sampling if specific conductance differs by more than 5 percent from the previous two field readings at the site. The buffer solution should have a specific conductance similar to the water that is being sampled. The specific conductance is also checked for accuracy with a buffer before sampling at each subsequent site where water-quality samples are collected if specific conductance differs by more than 5 percent from the previous two field readings. The measured value of the buffer is recorded in the water-quality PCFF (fig. 1) for the appropriate site. A specific conductance reading is taken after sampling the last well of the day for the end-of-day check, and the reading is recorded in the instrument calibration logbook (fig. 2). The specific conductance meter is recalibrated if at any time the reading of the buffer is off 
by \pm 5 percent for conductivity $\leq 100 \mu \mathrm{S} / \mathrm{cm}$ or \pm 3 percent for conductivity $>100 \mu \mathrm{S} / \mathrm{cm}$ (U.S. Geological Survey, variously dated, chapter 6.3).

\section{Calibration Procedure for Dissolved Oxygen}

The INL Project Office personnel calibrates dissolved oxygen meters each day during which water-quality samples are collected. Calibration of the meters can be performed in the laboratory or at the first site where water-quality samples are collected that day. The temperature at the time of calibration is recorded in the instrument calibration logbook (fig.2). The temperature and the atmospheric pressure are used to obtain the solubility of oxygen in water (U.S. Geological Survey, variously dated, table 6.2-6). The meter will be checked throughout the day to make sure that there are no bubbles on the inside of the membrane and that there are no tears or wrinkles in the membrane. If bubbles are present or the membrane is damaged, the membrane is changed.

\section{Decontamination Procedures}

Wells that are equipped with dedicated submersible or line-shaft turbine pumps do not require decontamination except for the equipment that is attached to the discharge pipe to accommodate the collection of a water sample. However, one wellbore volume of water is pumped from the well to remove stagnant water and to rinse and equilibrate the pump and delivery line.

Sample collection is facilitated and excess water is diverted away from the well head by fitting wells equipped with dedicated pumps with a portable discharge pipe about $2 \mathrm{ft}$ long. The discharge pipe has a 1.5-in. inside diameter and is equipped with a gate valve to control the flow rate. A series of joints, nipples, pipe sections, and valves to control the flow rate of the sampling ports are attached to the portable discharge line to enable splitting of the well discharge into three streams. The diameters of two of the streams are reduced to 0.25 -in. and have Tygon ${ }^{\mathrm{TM}}$ tubing attached to the discharge pipe. The first tube is attached to a flow-through chamber used for measuring temperature, $\mathrm{pH}$, specific conductance, and dissolved oxygen. The second tube is used for filling sample bottles. The third discharge stream is excess water and is diverted away from the well.

All fittings and pipes are stainless steel and are rinsed with deionized water before installation at the well head. For most wells, subsequent flushing with several hundred to thousands of gallons of purged well water further reduces the possibility of cross contamination with water from previously sampled wells. After sample collection, the fittings and pipes are rinsed with deionized water and capped prior to storage to further reduce the chance of cross contamination between wells. In an attempt to extend the longevity of pumps, a frequency reduction system is installed between the generator and the well pump to control the speed of the 5-horsepower pumps.

Production wells generally have a spigot at or near the well head and do not require special sample-collection equipment; decontamination consists of rinsing the spigot with pumped groundwater to remove foreign materials.

A bailer is used for collecting water samples from wells without dedicated pumps and wells with only a few feet of water in the wellbore. The bailer and the bailer line that enters the well are washed with water and detergent and rinsed with deionized water prior to use and rinsed with deionized water after use; samples of the rinsate are periodically collected and analyzed to 
document whether the equipment is contaminated by constituents of interest. At all wells, bailers are dedicated to the wells, reducing the chance for cross-contamination.

At the sites sampled for vertical definition of contaminants in the aquifer, stainless-steel thief sampling devices (bottles) are used to collect samples. The sample is delivered directly from the stainless-steel thief sampling bottles to a precleaned container which is used for filling the appropriate sample containers. Prior to sampling at each sampling port, the stainless-steel thief sampling bottles are washed with water and detergent and rinsed with deionized water. At the end of the day, the equipment is washed with water and detergent and rinsed with deionized water prior to storage to further reduce the chance of cross contamination.

For surface-water sites, grab samples are collected from the bank of the stream, using either a pre-cleaned Teflon ${ }^{\mathrm{TM}}$ container, or precleaned churn splitter. Prior to sampling, the selected container is washed with water and detergent and rinsed with deionized water and rinsed with deionized water after collection.

\section{Sample Collection}

Sample collection by the USGS at the INL generally follows protocols outlined in the USGS National Field Manual (U.S. Geological Survey [variously dated, chap. A4]) or in the USGS Idaho Water Science Center Quality-Assurance Plan for water-quality activities (Chris Mebane and Rhonda Weakland, U.S. Geological Survey, written commun., 2016); however, protocols sometimes are modified to collect the best representative water sample possible. At wells equipped with a dedicated pump, a volume of water equivalent to a minimum of one wellbore volume is pumped prior to collecting the samples; at many wells, more than one wellbore volume is pumped because of the amount of time needed for three stable readings. The purging of one well volume instead of three as recommended in the USGS National Field Manual is done to limit the amount of purge water that needs to be containerized at some wells. Bartholomay (1993) and Knobel (2006) generally found that sample concentrations would not be affected by a change in the number of volumes of water purged for the wells evaluated. The diameter of the borehole, rather than the volume of the casing, is used to calculate the minimum volume because of the potentially great difference between the two. Additionally, temperature, specific conductance, $\mathrm{pH}$, and dissolved oxygen are monitored periodically during pumping using methods described by Wood (1981), Hardy and others (1989), and U.S. Geological Survey (variously dated, chapter A6). Field measurements made immediately prior to sample collection are used to represent those for the sample. A water sample is collected when $\mathrm{pH}$ measurements are within $+/-0.1$ standard units, water temperature is $+/-0.2^{\circ} \mathrm{C}$, and specific conductance readings are within 5 percent of each other for three consecutive readings taken 3-5 minutes apart, indicating probable hydraulic and chemical stability. Samples are collected using the following steps:

1. The field person responsible for collecting the water sample wears disposable gloves and stands in a position where neither the collector nor the sample can become contaminated.

2. The outside of the sample delivery line is thoroughly rinsed with water pumped from the well.

3. If appropriate, sample containers and filtration equipment are thoroughly rinsed with water pumped from the well or surface-water site before being used. A new, disposable capsule filter with a 0.45 -micron-membrane filter is used at each site. The capsule filter is inverted to clear trapped air bubbles and two liters of deionized water is used to rinse the 
capsule filter prior to sample collection. This removes any surfactants that are adhered to the filter.

4. For groundwater samples from wells equipped with dedicated pumps, the capsule filter is connected to the sample port with precleaned Tygon ${ }^{\mathrm{TM}}$ tubing; unfiltered samples are collected directly from the sample port. For surface-water samples, thief samples, and bailer samples, a grab sample is collected in a precleaned container and the precleaned inlet tubing of a peristaltic pump is placed into the container to supply sample water to the capsule filter. Unfiltered samples are collected by submersing the sample container into the surface-water body or drawing water from a precleaned container.

5. Samples are capped and moved into the mobile field laboratory where they are uncapped and preserved (if appropriate) as described in table 1. A new pair of gloves, safety glasses, and a laboratory apron are worn while preserving samples.

6. The bottles are capped. The bottles are then labeled (see fig. 3 for example of label). An alternate method for labeling containers is to record information directly on the sample container using a permanent marker. Recording the information both on a label and directly on the bottle is preferable.

7. Field measurements are made again after samples are collected. If the temperature differs by more than $0.5^{\circ} \mathrm{C}$, the $\mathrm{pH}$ differs by more than 0.1 units, or the specific conductance differs by more than 5 percent, the measurements are verified and a second set of samples is collected. The second set of samples replaces the original set of samples.

8. An analytical services request form is completed for use by each laboratory to which the sample(s) will be sent for analysis (see figs. 4-6 for examples).

9. The water samples are chilled to $4{ }^{\circ} \mathrm{C}$ if necessary and stored in the field laboratory until they can be transferred to a secured storage area. Samples are sent biweekly to the USGS NWQL and daily to TestAmerica and GEL Laboratories for analysis; the samples are transported in a sealed ice chest by a contract carrier and overnight delivery is stipulated for water samples for analyses of nutrients, VOCs, and other time-sensitive constituents. Samples sent to the RESL for analyses are hand carried to the laboratory at the end of the sampling event.

10. All equipment is decontaminated with deionized water and, if necessary, organic-free water. 
ANALYTICAL SERVICES REQUEST

U.S. GEOLOGICAL SURVEY - NATIONAL WATER QUALITY LABORATORY

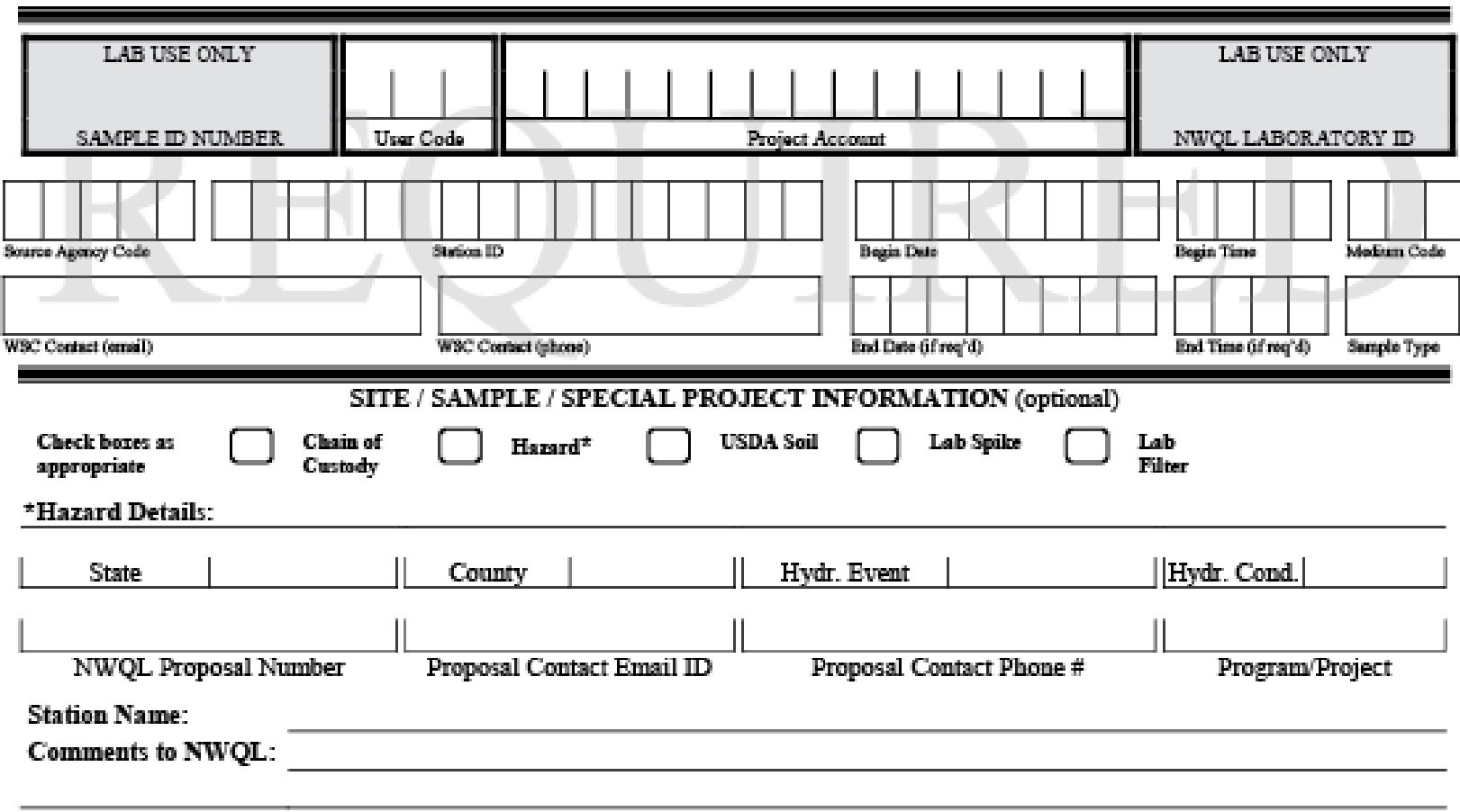

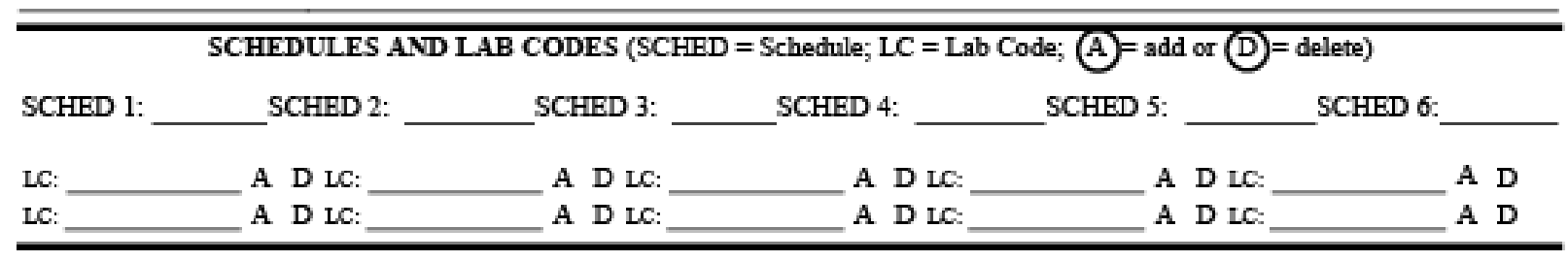

\begin{tabular}{|c|c|c|c|c|c|c|}
\hline \multirow{3}{*}{$\begin{array}{l}\text { ALF } \\
\text { BGC }\end{array}$} & \multicolumn{6}{|c|}{ SHIPPING INFORMATION (Number of containers sent) } \\
\hline & FA & GCC & POCIS-SPMD & SUSO & & UAS \\
\hline & FAM & GCV & RA & TBI & & WCA \\
\hline $\mathrm{CC}$ & FAR & HFL & RAM & TBY & & \\
\hline CHL & FCA & HUN & RAR & TOC & & \\
\hline $\mathrm{CU}$ & FCC & MBAS & $\mathrm{RCB}$ & TPCN & & \\
\hline CUR & FCCVT & OXW & RU & & & \\
\hline DIC & FU & PEST & SAS & RUR & $\overline{\text { Time: }}$ & : \\
\hline DOC & FUS & PHARM & SUR & RURCV & Time: & : \\
\hline
\end{tabular}

NWQL Login Comments (Lab ouly):

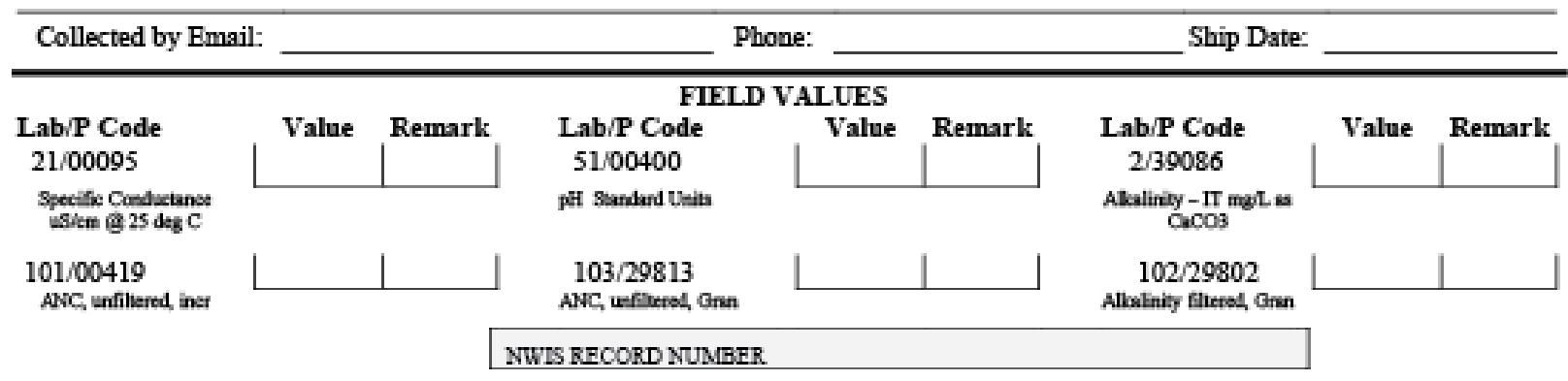

Form 9-3094

Figure 4. Analytical services request form for the National Water Quality Laboratory. 


\section{SAMPLE RECORD SHEET}

\begin{tabular}{|c|c|c|c|c|c|c|c|}
\hline $\begin{array}{c}\text { Sample } \\
\text { identifier }\end{array}$ & $\begin{array}{c}\text { Reference } \\
\text { date }\end{array}$ & $\begin{array}{l}\text { Wt/vol } \\
\text { units }\end{array}$ & Name & Site & $\begin{array}{l}\text { Sample } \\
\text { matrix }\end{array}$ & $\begin{array}{c}\text { Special } \\
\text { instructions }\end{array}$ & $\begin{array}{c}\text { RESL } \\
\text { analytes }\end{array}$ \\
\hline & & & & & & & \\
\hline & & & & & & & \\
\hline & & & & & & & \\
\hline & & & & & & & \\
\hline & & & & & & & \\
\hline & & & & & & & \\
\hline & & & & & & & \\
\hline & & & & & & & \\
\hline & & & & & & & \\
\hline & & & & & & & \\
\hline & & & & & & & \\
\hline & & & & & & & \\
\hline & & & & & & & \\
\hline
\end{tabular}

Figure 5. Sample record sheet for the Radiological and Environmental Sciences Laboratory 
U.S. GEOLOGICAL SURVEY - ANALYTICAL SERVICES REQUEST (ASR)

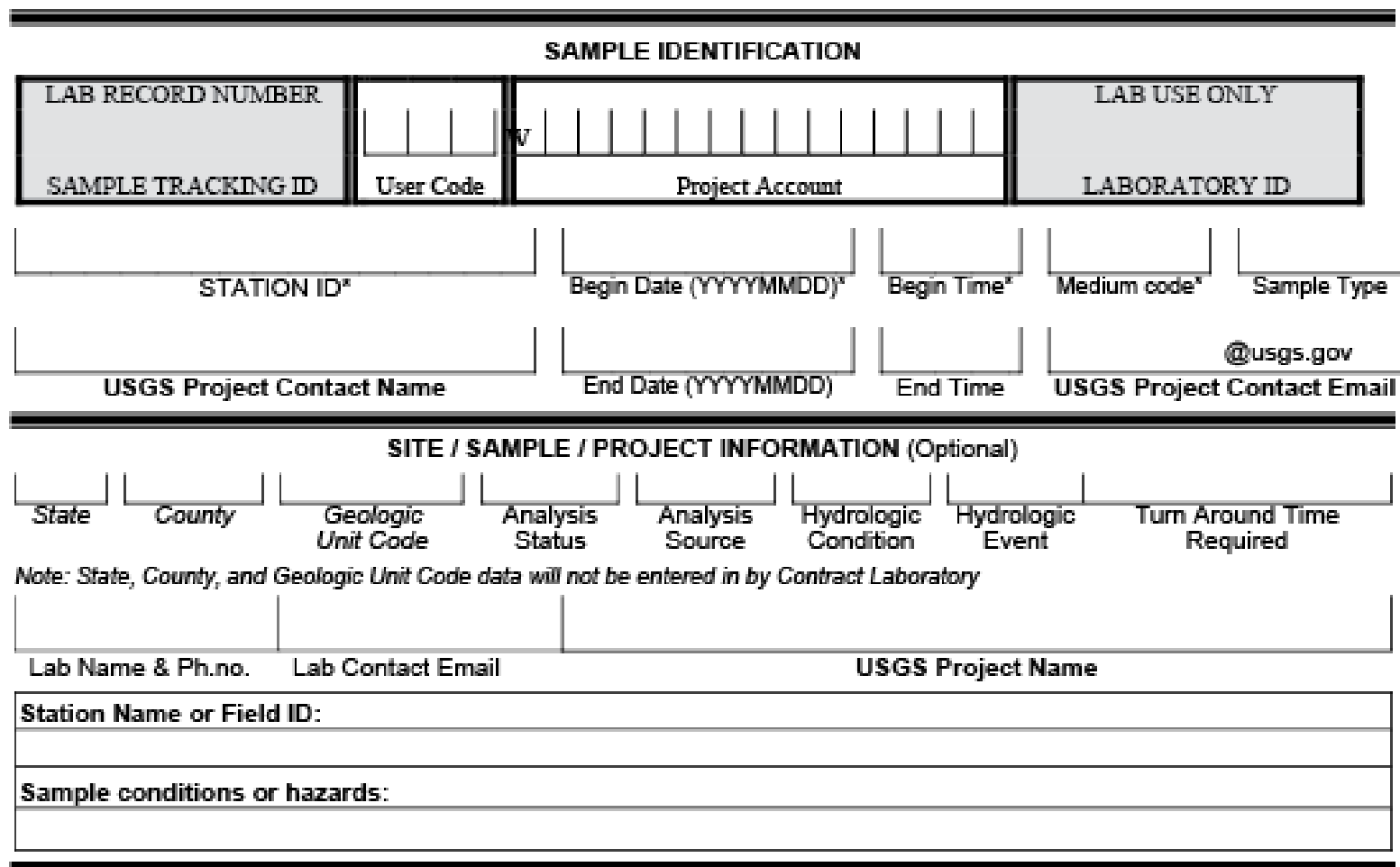

ANALYTICAL WORK REQUESTS: SCHEDULES AND CONTRACT ITEM NUMBERS (CINS)

Note: Contract Item Numbers (CINs) are used as Lab Codes for this specific ASR.

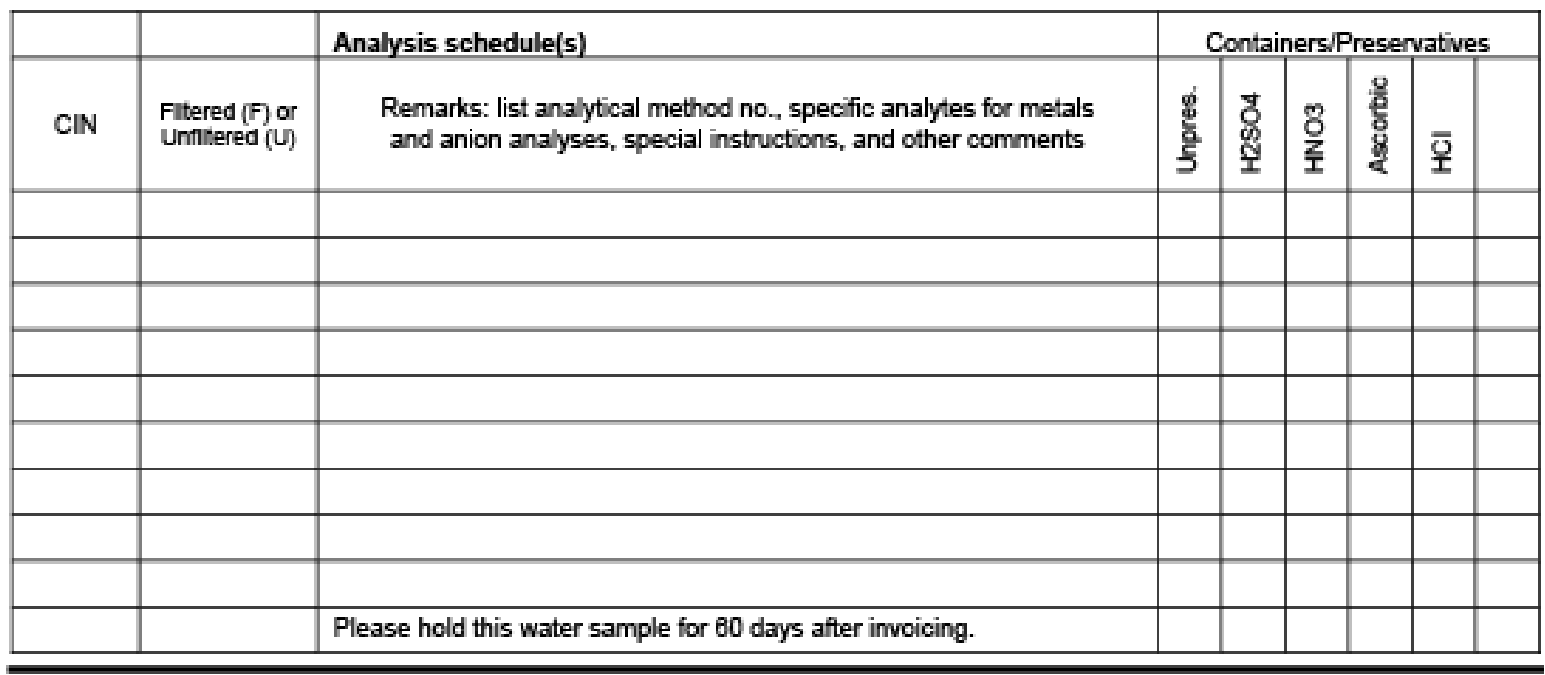

CHAIN OF CUSTODY RECORD

\begin{tabular}{|l|l|l|l|l|l|}
\hline ASR: Relinquished by: & & Date: & & Time: & \\
\hline ASR: Received by: & & Date: & & Time: & \\
\hline
\end{tabular}

USGS DODESP Contract ASR, revision 2.2, $010 \mathrm{ct} 2010$

Figure 6. Sample request and chain-of-custody record for GEL Laboratories, LLC, and TestAmerica Laboratories. 


\begin{tabular}{|c|c|c|c|c|c|c|c|c|c|c|c|c|c|c|c|}
\hline \multirow{2}{*}{ 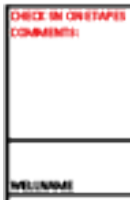 } & \multicolumn{3}{|c|}{ STEEL TAPE $\approx .1(1000 \pi)$} & \multicolumn{2}{|c|}{ |ETAPE 1 (sn 38303) } & \multicolumn{2}{|c|}{ ETAPE 2 (sn1437380) } & \multicolumn{2}{|c|}{ ETAPE 3 (sn 36592) } & \multicolumn{2}{|c|}{ |ETAPE 4 (sn1437381) } & \multicolumn{2}{|c|}{ ETAPE 5 (sn36529) } & \multicolumn{2}{|c|}{ ETAPE $6(\operatorname{sn} 16374022)$} \\
\hline & $\begin{array}{l}\text { grat ver nas } \\
\text { mover }\end{array}$ & $\operatorname{mis} i n$ & 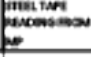 & 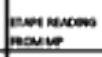 & 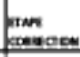 & $\begin{array}{l}\text { Tun weros } \\
\text { maive }\end{array}$ & ener & 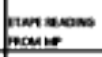 & mon & 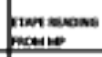 & mentionan & monen nucers & 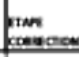 & 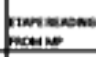 & eor \\
\hline US65 55 & & & & & & & & & & & & & & & \\
\hline tentens. & & & & & & & & & & & & & & & \\
\hline US65 61 & & & & & & & & & & & & & & & \\
\hline andar. & & & & & & & & & & & & & & & \\
\hline USGS62 & & & & & & & & & & & & & & & \\
\hline tantar & & & & & & & & & & & & & & & \\
\hline US65 19 & & & & & & & & & & & & & & & \\
\hline Lanes. & & & & & & & & & & & & & & & \\
\hline US65 97 & & & & & & & & & & & & & & & \\
\hline andens. & & & & & & & & & & & & & & & \\
\hline USGS 142 & & & & & & & & & & & & & & & \\
\hline Lanesen. & & & & & & & & & & & & & & & \\
\hline USGS 142A & & & & & & & & & & & & & & & \\
\hline anowe. & & & & & & & & & & & & & & & \\
\hline US65 120 & & & & & & & & & & & & & & & \\
\hline tants. & & & & & & & & & & & & & & & \\
\hline USG5 196 & & & & & & & & & & & & & & & \\
\hline Lawen. & & & & & & & & & & & & & & & \\
\hline US65 8 & & & & & & & & & & & & & & & \\
\hline anem. & & & & & & & & & & & & & & & \\
\hline $\mathrm{CH}_{1}$ & & & & & & & & & & & & & & & \\
\hline . & & & & & & & & & & & & & & & \\
\hline
\end{tabular}

Figure 7. Electronic tape calibration form.

Some wells completed in the perched-water zones do not contain or produce enough water to be sampled with a pump. For these wells, a $1,000-\mathrm{mL}$ Teflon ${ }^{\mathrm{TM}}$ bailer is used for sample collection. The well is bailed until enough water is collected for all the samples required or until the well is bailed dry. When the bailer is retrieved, its contents are placed either directly in bottles for raw samples or in a precleaned container as described in step 4 above. Field measurements are made on excess water from the bailer or in the precleaned container. After the sample bottle is filled with either raw or filtered water, samples are preserved appropriately, labeled, stored, and shipped as described in steps 6, 8, and 9 above.

At the sites sampled for vertical definition of contaminants in the aquifer, the evacuated stainless-steel thief sampling devices (bottles) are lowered to the zone to be sampled, mated to the sampling port, and filled with formation water. The stainless-steel bottles are raised to the surface and emptied into a precleaned container; the water is processed to fill sample containers as described in step 4 above. Field measurements are made on excess water from the precleaned container. After the sample bottle is filled with either raw or filtered water, samples are preserved appropriately, labeled, stored, and shipped as described in steps 6,8 , and 9 above. This 
process is repeated until sufficient water has been collected to fill all of the required sample containers and to make all necessary field measurements.

At sites where containerization of purge water is required, the sampling stream is split to accommodate measurement of the field-water-quality indicators (temperature, $\mathrm{pH}$, specific conductance, and dissolved oxygen) and to collect samples. Additionally, excess purge water is collected at the discharge point in buckets that are subsequently emptied in the trailer-mounted containers and also routed through canvas hoses to the trailer-mounted containers. The containerized purge water is subsequently transported to an approved disposal site.

Wells inside the Advanced Test Reactor Complex and the boundary of the Resource Conservation and Recovery Act Listed Waste Polygon (Knobel, 2006) require containerization of all purge water. These wells are purged at slow rates to minimize the amount of purge water. After three stable readings of temperature, $\mathrm{pH}$, specific conductance, and dissolved oxygen are obtained, and at least one wellbore volume has been purged, samples are collected.

Production wells at the INL generally are connected to water distribution systems, and they cycle on and off in response to system water demands. Because of the frequent pumping cycles, water in the system is representative of aquifer water, and only sample collection lines require purging prior to sampling. In many cases, the production wells cycle off before the multiparameter field measurement instruments can stabilize. In this case, the requirement for stable readings is waived; however, an end of day check must be satisfactory, or the well is resampled.

Conditions at the well during sample collection are recorded in a PCFF (fig. 1), and the analytical services request forms (figs. 4-6) are used to track samples from the time of collection until delivery to the RESL or until mailing to the USGS NWQL, GEL Laboratories, LLC, TestAmerica Laboratories, or other labs used. These records are available for inspection at the USGS INL Project Office. The chain-of-custody record for the current NRF contract laboratories, GEL Laboratories, LLC and TestAmerica Laboratories, is shown in figure 6. The original is sent to the laboratory with samples and a copy is provided to the NRF.

\section{Data Management for Water Quality}

All valid data analyses are entered into the NWIS database. The method by which the data are entered varies with the capabilities of the laboratory that performed the analyses.

The USGS NWQL and other USGS laboratories format the analytical results into NWIScompatible batch input files. An electronic copy of the data is sent to the Water Science Center via the QW-Data Transfer System for input to the NWIS. Following processing, the batch output files are made available for the appropriate field/project office or individual requestor.

Some contract laboratories will provide analysis results in spreadsheet format, tabdelimited text files, or paper copy. In these instances, the data are formatted into NWIScompatible batch files or manually entered and checked for correctness by a second person. Field measurements made during sample collection and other pertinent metadata are manually entered once the laboratory data are available in NWIS.

Data management begins with a file for tracking requested analyses at each data collection site. This data-tracking file shows which analyses have been requested, if the data are available in the NWIS database and whether field parameters and other metadata have been entered. Data are validated by review for reasonableness by comparing to historical values and by utilizing the water-quality data checks function available through the NWIS Data Portal and Reports Application. Laboratory reruns may be requested for data results of questionable accuracy. When the data has been reviewed, the analyst can decide to accept or reject the results. 
This decision is reflected by using the Data Quality Indicator (DQI) code in the NWIS database analytical record. In most instances, the DQI code is changed from presumed satisfactory (S) to reviewed and accepted $(\mathrm{R})$. Water quality data are reviewed and accepted by the INL water quality database administrator generally within 150 days after the data are available in NWIS.

\section{Field Methods for Water-Level Measurements}

Calibration of water-level measurement equipment and use of appropriate field procedures are crucial in assuring reliable water-level data are collected from open boreholes, data loggers, and MLMS. All sites are surveyed with known measuring points and the waterlevel is calculated from a known land surface datum (LSD).

\section{Calibration of Electric Tapes}

The USGS INL Project Office started the use of e-tapes in 2003; prior to 2003, stainless steel tapes were used. E-tapes are calibrated against a reference steel tape that is maintained in the office for calibration use only. Calibration is conducted downhole in designated boreholes at various intervals that represent WL monitoring depths. All e-tapes are initially calibrated before use in the field and recalibrated annually or more frequently if it is used often or if the tape has been subjected to abnormal stress that may have caused it to stretch. With the establishment of the USGS internal policy GW2015.03 "Policy for quality assurance checks of steel and electric groundwater level measurement tapes." the INL Project Office started sending tapes in for calibration at the Hydrologic (HIF) Instrumentation Facility. Results from HIF created several questions on reproducibility of the calibrations, so the INL Project Office decided to stay with current calibration procedures described here to maintain long-term data comparability. Discussion with HIF and the Water Science field team are included in appendix 9. An inventory of e-tapes is given in appendix 7. The following procedures modified from Cunningham and Schalk, 2011 are used for calibration and entered on a field calibration sheet (fig. 7):

1. Check the distance from the probe's sensor to the nearest foot marker on the tape to ensure that this distance puts the sensor at the zero-foot point for the tape. If it does not, a correction must be applied to all depth-to-water measurements.

2. Check the circuitry of the electric tape before lowering the probe into the well by dipping the probe into tap water and observing whether the indicator light and beeper are functioning properly to indicate a closed circuit.

3. Compare water-level measurements made with the electric tape with those made with a reference steel tape in several wells that span the range of depths to water that is anticipated. Measurements should agree to within $+/-0.02$ foot. If measurements are not repeatable to this standard, then a correction factor based on a regression analysis is developed and applied to measurements made with the e-tape. The e-tape correction files are stored on the INL Project Office Server and posted on the corresponding e-tape.

\section{Collection Procedures for Water Levels}

All water-level measurements taken with an e-tape have a calibration and measuring point (MP) correction applied to them. Several wells also have deviation corrections applied; these corrections have been calculated from geophysical deviation log files. All data are entered in Site Visit Mobile Aquarius (SVMAQ) for electronic download and on a field sheet for back up (fig. 8). 
1. Using the e-tape, make all readings using the same deflection point on the indicator scale, light intensity, or sound so that water levels will be consistent between measurements.

2. Lower the electrode probe slowly into the well until the indicator shows that the circuit is closed and contact with the water surface is made. Take a second reading to check measurement within $+/-0.02 \mathrm{ft}$. of each other at the known MP; this is the depth to water. Be sure you have a solid beep and verify the reading by lowering the tape in the water table you still have a solid beep. Record the depth to water, date and time of the measurement on the water level field sheet (fig. 8) and into SVMAQ for electronic download.

3. After completing the water level measurement, rewind the tape and rinse the end of the tape with deionized water prior to storing for travel to the next well.

4. Maintain the tape in good working condition by periodically checking the tape for breaks, kinks, and possible stretch.

5. When recording the water levels on the field sheet and into SVMAQ, apply the MP correction to get the depth to water in feet below LSD. All MP descriptions from NWIS are available in the SVMAQ program. Apply any deviation and e-tape corrections. View historic data and the hydrograph on the SVMAQ program to verify the water-level is reasonable. 


\begin{tabular}{|c|c|c|c|c|c|c|c|c|c|c|}
\hline Well name & January & \begin{tabular}{|c} 
Measuring \\
point
\end{tabular} & $\begin{array}{l}\text { Deviation } \\
\text { correction }\end{array}$ & Site identifier & Latitude longitude & Remarks & \begin{tabular}{|c|} 
Etape \\
reading
\end{tabular} & Date & Time & $\begin{array}{c}\text { Water } \\
\text { level (raw) }\end{array}$ \\
\hline USGS 2 & $A Q$ & 2.13 & -0.3 & 433320112432301 & 433319.871124321 .28 & & & & & \\
\hline USGS 5 & $A Q$ & 1.60 & NA & 433543112493801 & 433542.751124937 .65 & & & & & \\
\hline USGS 6 & $A Q$ & 2.07 & $\mathrm{NA}$ & 434031112453701 & 434031.121124536 .66 & & & & & \\
\hline USGS 7 & $A Q$ & 1.68 & NA & 434915112443901 & 434914.811124439 .87 & & & & & \\
\hline USGS 8 & $A Q$ & 2.11 & SEE CHART & 433121113115801 & 433120.511131157 .43 & & & & & \\
\hline USGS 11 & $A Q$ & 2.34 & NA & 432336113064201 & 432336.181130642 .52 & & & & & \\
\hline USGS 14 & $A Q$ & 1.59 & NA & 432019112563201 & 432019.271125631 .92 & & & & & \\
\hline USGS 15 & $A Q$ & 1.33 & NA & 434234112551701 & 434234.841125517 .35 & & & & & \\
\hline USGS 17 & $A Q$ & 2.53 & NA & 433937112515401 & 433936.421125154 .27 & & & & & \\
\hline USGS 18 & $A Q$ & 1.78 & NA & 434540112440901 & 434540.701124409 .29 & & & & & \\
\hline USGS 19 & AM & 2.08 & NA & 434426112575701 & 434426.681125756 .58 & & & & & \\
\hline USGS 20 & $A Q$ & 1.96 & NA & 433253112545901 & 433252.791125459 .41 & & & & & \\
\hline USGS 22 & $A Q$ & 1.69 & -0.2 & 433422113031701 & 433422.281130321 .09 & & & & & \\
\hline USGS 23 & $A Q$ & 2.90 & NA & 434055112595901 & 434055.151130000 .02 & & & & & \\
\hline USGS 26 & $A Q$ & 2.10 & NA & 435212112394001 & 435210.551123940 .74 & & & & & \\
\hline USGS 27 & AM & 2.26 & NA & 434851112321801 & 434851.221123218 .90 & & & & & \\
\hline USGS 39 & $A Q$ & 1.63 & -0.2 & 433343112570001 & 433343.191125701 .42 & & & & & \\
\hline USGS 54 & $P Q$ & 1.67 & NA & 433503112572801 & 433503.001125728 .00 & & & & & \\
\hline USGS 2 & $A Q$ & 2.13 & -0.3 & 433320112432301 & 433319.871124321 .28 & & & & & \\
\hline USGS 55 & $P Q$ & 1.72 & NA & 433508112573001 & 433508.001125729 .00 & & & & & \\
\hline USGS 57 & $A Q$ & 2.21 & NA & 433344112562601 & 433344.041125626 .00 & & & & & \\
\hline USGS 60 & $P Q$ & 2.06 & NA & 433456112571901 & 433456.001125719 .00 & & & & & \\
\hline USGS 61 & $P Q$ & 0.66 & NA & 433453112571601 & 433453.001125715 .00 & & & & & \\
\hline USGS 62 & $P Q$ & 1.86 & NA & 433446112570701 & 433446.001125705 .00 & & & & & \\
\hline USGS 63 & $P Q$ & 1.76 & NA & 433455112574001 & 433455.001125740 .00 & & & & & \\
\hline USGS 65 & $A Q$ & 0.83 & NA & 433447112574501 & 433446.851125747 .13 & & & & & \\
\hline USGS 66 & $P Q$ & 1.80 & NA & 433436112564801 & 433439.001125657 .00 & & & & & \\
\hline
\end{tabular}

Figure 8. Sample water level field sheet. 
January Water Levels

\begin{tabular}{|c|c|c|c|c|c|c|c|c|c|}
\hline USGS 68 & $P Q$ & 3.16 & NA & 433516112573901 & 433516.001125740 .00 & & & & \\
\hline USGS 69 & $P Q$ & 2.47 & NA & 433450112573001 & 433450.001125729 .00 & & & & \\
\hline USGS 70 & $P Q$ & 2.16 & NA & 433504112571001 & 433504.001125710 .00 & & & & \\
\hline USGS 71 & $P Q$ & 1.52 & NA & 433439112571501 & 433439.001125714 .00 & & & & \\
\hline USGS 72 & $P Q$ & 2.00 & NA & 433519112574601 & 433519.001125747 .00 & & & & \\
\hline USGS 73 & $P Q$ & 3.90 & NA & 433502112575401 & 433502.001125753 .00 & & & & \\
\hline USGS 78 & PM & 1.06 & NA & 433413112573501 & 433413.001125735 .00 & & & & \\
\hline USGS 82 & $A Q$ & 1.77 & NA & 433401112551001 & 433400.931125510 .34 & & & & \\
\hline USGS 83 & $A Q$ & 2.67 & NA & 433023112561501 & 433023.031125615 .28 & & & & \\
\hline USGS 84 & $A Q$ & 1.96 & NA & 433356112574201 & 433356.511125741 .84 & & & & \\
\hline USGS 85 & $A Q$ & 2.53 & NA & 433246112571201 & 433246.231125711 .89 & & & & \\
\hline USGS 2 & $A Q$ & 2.13 & -0.3 & 433320112432301 & 433319.871124321 .28 & & & & \\
\hline USGS 86 & $A Q$ & 2.23 & NA & 432935113080001 & 432934.791130801 .44 & & & & \\
\hline USGS 89 & $A Q$ & 1.88 & NA & 433005113032801 & 433005.671130331 .73 & & & & \\
\hline USGS 92 & $P Q$ & 10.61 & NA & 433000113025301 & 433000.001130253 .00 & & & & \\
\hline USGS 97 & AM & 1.78 & NA & 433807112551501 & 433806.771125516 .76 & & & & \\
\hline USGS 100 & $A Q$ & 2.19 & NA & 433503112400701 & 433502.721124006 .67 & & & & \\
\hline USGS 101 & $A Q$ & 2.20 & SEE CHART & 433255112381801 & 433255.751123819 .91 & & & & \\
\hline USGS 104 & $A Q$ & 2.99 & NA & 432856112560801 & 432856.071125608 .14 & & & & \\
\hline USGS 116 & $A Q$ & 2.55 & SEE CHART & 433331112553201 & 433331.551125532 .67 & & & & \\
\hline USGS 120 & AM & 1.65 & SEE CHART & 432919113031501 & 432919.191130314 .01 & & & & \\
\hline USGS 125 & $A Q$ & 2.20 & SEE CHART & 432602113052801 & 432559.411130530 .37 & & & & \\
\hline USGS 126B & $A Q$ & 1.20 & NA & 435529112471401 & 435528.511124713 .67 & & & & \\
\hline USGS 127 & $A Q$ & 1.79 & NA & 433058112572201 & 433058.281125722 .04 & & & & \\
\hline USGS 130 & $\mathrm{AQ}$ & 1.44 & NA & 433130112562801 & 433130.671125628 .40 & & & & \\
\hline USGS 139A & $A Q$ & 1.47 & NA & 433823112460402 & 433823.231124603 .58 & & & & \\
\hline USGS 139B & $A Q$ & 1.46 & NA & 433823112460401 & 433823.231124603 .58 & & & & \\
\hline USGS 142 & AM & 0.96 & NA & 433837113010901 & 433837.321130109 .41 & & & & \\
\hline
\end{tabular}

Figure 8.-Continued 


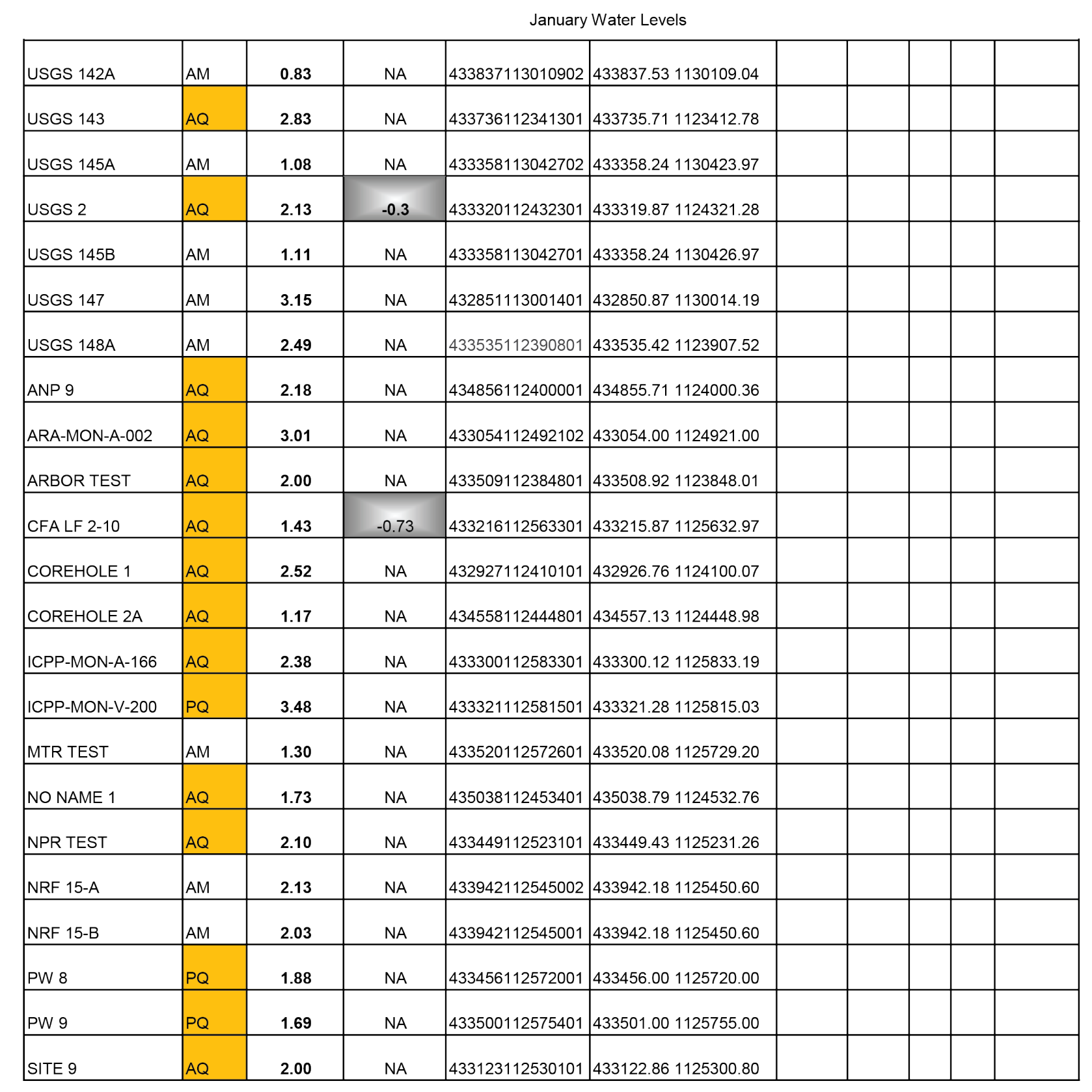

Figure 8.-Continued 


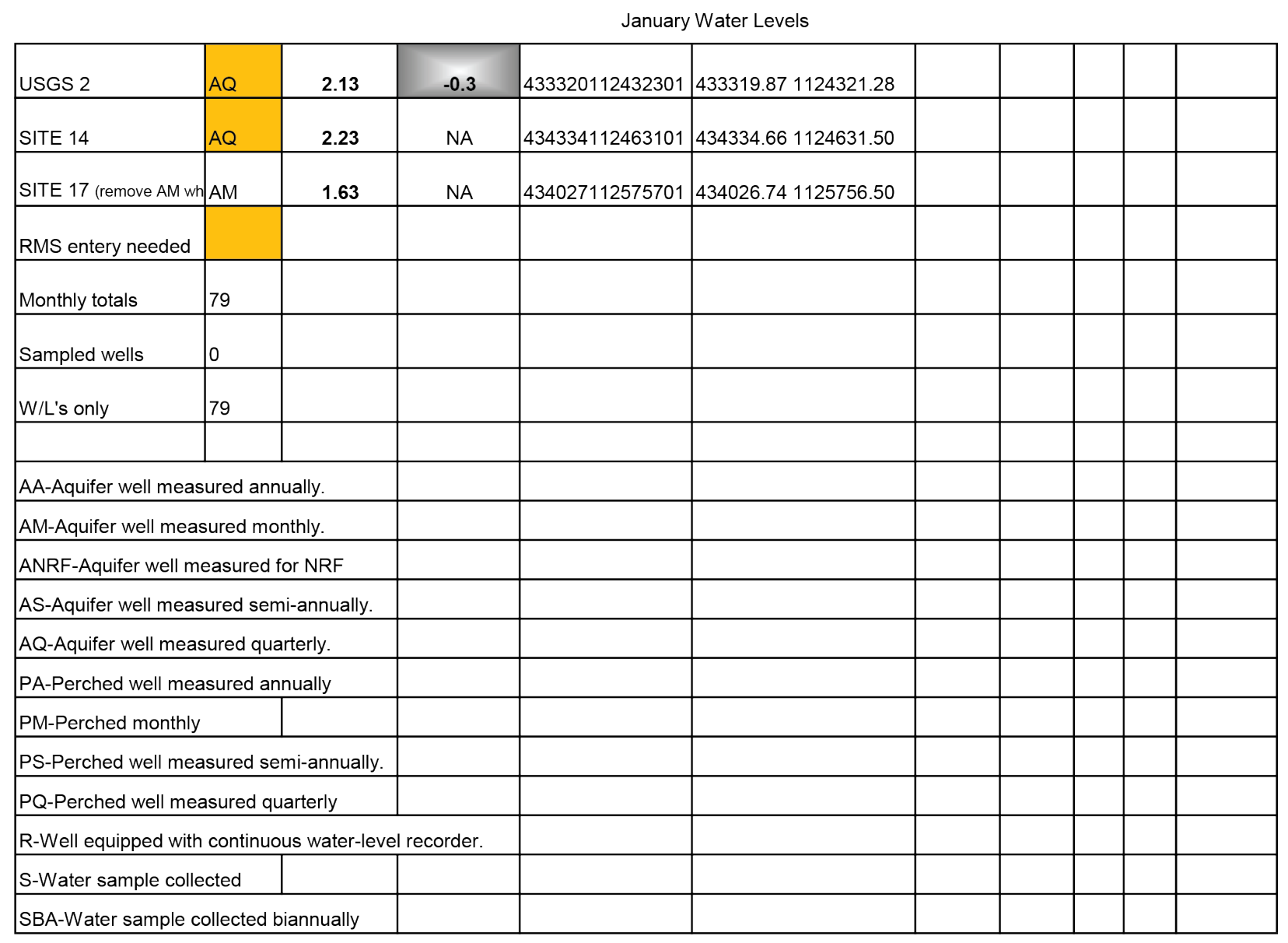

Figure 8.-Continued

\section{Calibration and Collection Procedures of Submersible Pressure Transducer and Data Loggers}

Water-level measurements for pressure transducers will be made to the nearest 0.01 foot. The accuracy of a pressure transducer differs with the manufacturer, measurement range, and depth to water. The measurement error and accuracy standard for most situations for the transducer is 0.01 foot. Pressure transducers are subject to drift, offset and slippage of the suspension system. For this reason, the transducer readings are checked against the water level in the well on every visit, and the transducer is recalibrated periodically according to manufacturer specifications.

The USGS INL Project office maintains nine vented pressure transducers in observation wells for long-term continuous monitoring of water levels. These wells are scheduled for quarterly visits in order to download the data and calibrate the transducers. The procedure (Cunningham and Schalk, 2011) for retrieving water-level measurements from pressure transducers and maintaining the pressure transducers is:

1. Retrieve groundwater data by using instrument or data-logger software.

2. Inspect the equipment to confirm that installation is operating properly. Document the current water level recorded by the sensor. 
3. Measure the depth to water in the well using a calibrated e-tape to obtain an accurate water-level measurement to compare with the water level measured by the transducer. If the water-level measurement and transducer reading differ, raise the transducer in the well slightly and take a reading to confirm that the sensor is working. Observe for possible cable kinks or slippage. Return transducer to its original position.

4. Recalibrate the transducer if necessary.

5. Verify the logger channel and scan intervals, document any changes to the data logger program, and reactivate the data logger. Make sure the data logger is operating prior to departure.

\section{Calibration and Collection Procedures for Multilevel Pressure Measurements}

Multilevel monitoring ports are calibrated by measuring the depth of the port below land surface with an e-tape and correcting the depth due to deviation as described in Fisher and Twining (2011). Fluid pressure measurements from 12 multilevel monitoring wells are made using a portable sampling probe that is lowered into the multiport casing from land surface and positioned at a selected measurement port coupling as described by Fisher and Twining (2011). Atmospheric pressure is monitored at land surface using a hand-held barometric sensor. Field measurements are recorded on a field form (fig. 9).

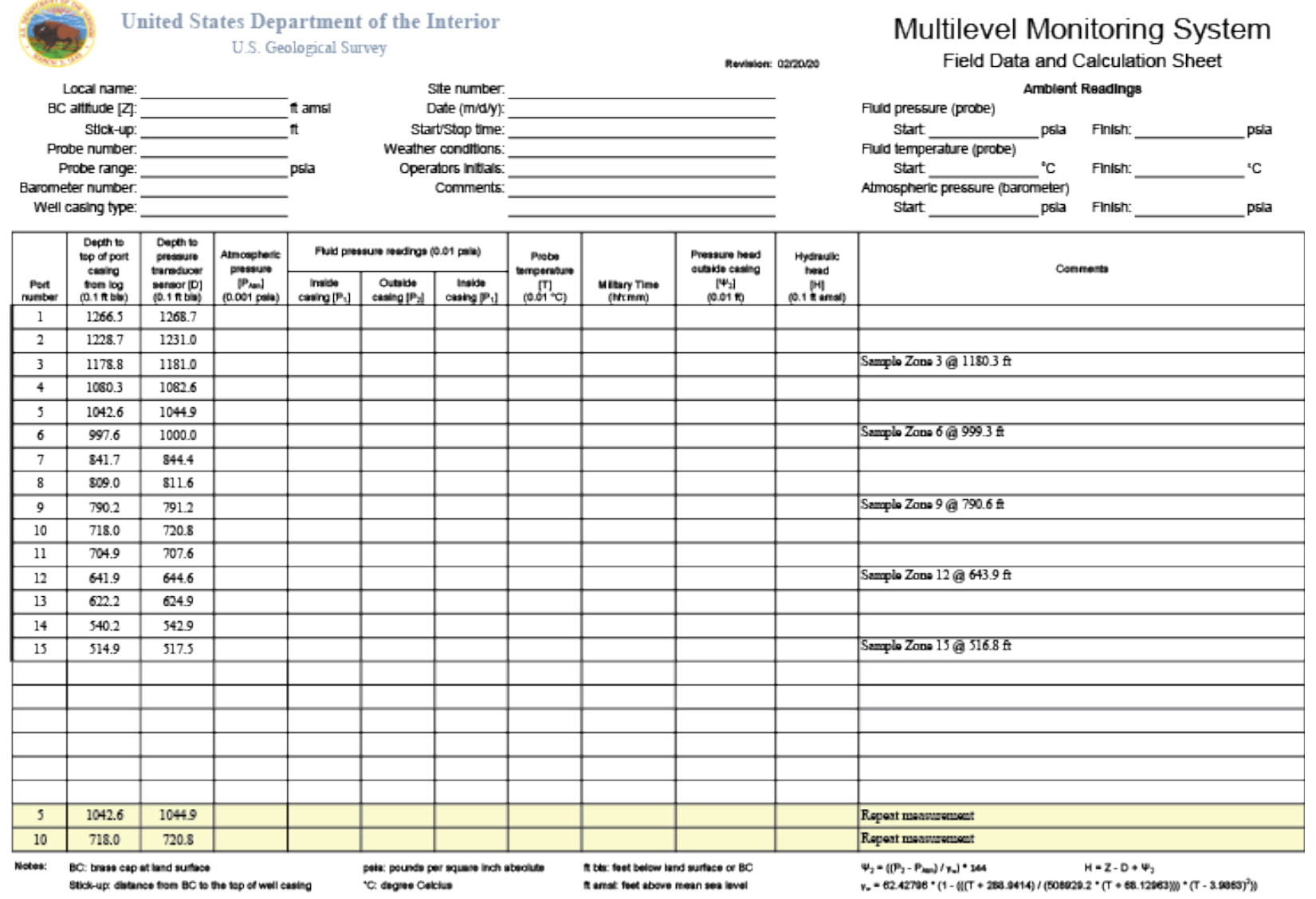

Figure 9. Field sheet for multilevel pressure and temperature measurements. 


\section{Data Management for Water Levels}

The INL project office works by the USGS WMA water level data processing records management system of "Operator," "Analyst," and "Approver." The Operator is the person assigned to make site visits and collect field data and often serves as the Analyst. Records will be analyzed for discrete periods of time by a hydrographer (the Analyst); more than one Analyst may be needed in some situations. A second hydrographer (the Approver) will examine the analysis and either approve the record, or returns it to the Analyst, informing them of what needs to be resolved in order for the records to be approved. After data are approved, any additional examination of groundwater-level records will be considered an audit.

Discrete groundwater-level records are stored in the Groundwater Site Information System (GWSI) where the data aging codes are: 'In Review, presumed satisfactory' (S), 'Reviewed and Accepted, approved' (R), and 'Rejected' (Q). While groundwater-level records are stored in GWSI, records should remain coded as 'In Review,' equivalent to the new 'working' state, until they have been analyzed according to guidelines and they are either approved or rejected (GW2017.04 Policy and Procedures for Processing and Publishing Discrete Groundwater-Level Records). Non-routine auditing is done within the Water Science Center and new procedures are in process for Internal Technical Review Procedures (ITRP's).

The INL Operator utilizes SVMAQ for field groundwater data entry and processing as recommended by the USGS WMA. The use of mobile technology improves workflow processes in the collection, processing, and quality assurance of our groundwater data. The Analyst should begin analyzing and processing the SVMAQ .xml files as soon as practical after the field visit, ideally within 1 week of completing field work. When the field trip is processed the .xml files are archived on the INL Project Office server. The Approver will check field notes, possible errors, applied corrections and upload the .xml file to GWSI. All water level data are considered provisional data, 'In Review, presumed satisfactory,' (S) until it has been reviewed and approved. The Approver then reviews hydrograghs and approves data (R). At this stage the Operator completes a Station Analysis report for the period of analysis in the Record Management System (RMS).

The INL Operator collects multilevel pressure measurements on an electronic field form that is reviewed. The Analyst should begin analyzing and processing the files as soon as practical after the field visit, ideally within 1 week of completing field work. When the field trip is processed the .xml files are archived on the INL Project Office server. The Approver will check field notes, possible errors, applied corrections and upload a batch file to GWSI. All water level data are considered provisional data, 'In Review, presumed satisfactory,' (S) until it has been reviewed and approved. Approver then reviews hydrograghs and approves data (R).

Multilevel pressure measurements are calculated and reviewed. The processed data are uploaded to NWIS. The data are reviewed and approved by at least 120 days after collection.

Time-series data are stored in Aquarius where the data aging codes are:

1. Working: Raw data collected and entered into NWIS are in the working data state. These data are as accurate as possible following current best practices and in compliance with Technical Office and Water Mission Area policies for collection and database entry. Working data are displayed on NWISWeb as "Provisional."

2. Analyzed: The analyzed state is defined as fully processed time-series data following current guidelines. Analysis of the data should begin as soon as practical after the field visit. If, during the analysis of a period, it is determined that there are insufficient data to 
complete the analysis, the data state will remain as working until additional data are collected and issues are resolved. Analyzed records must have a complete station analysis for the analysis period. Analyzed data are labeled as such in the records management system and displayed on NWISWeb as "Provisional."

3. Approved: The approved data state is defined as completely analyzed water-level data, including examination for errors and proper interpretation. Following full resolution of any problems identified, the record is set to Approved by a second hydrographer. Approved data are labeled as such in the records management system, shown in GWSI as "Reviewed and Accepted, approved," and displayed on NWISWeb as "Approved" and are considered "published."

Non-routine Auditing of Groundwater-Level Records: Non-routine audits occur anytime an aspect of an approved record is re-examined. For example, an end user may question a published period of unusually low water levels or a series of spikes in the historic water-level record. Errors found during non-routine audits are subject to defined error threshold criteria for revisions. Non-routine audits do not have any required tasks aside from documentation of the audit to include the date of the audit, the auditor, the data examined, the reason it was examined, and the outcome of the audit to include a discussion of potential revisions, if any. Another example of a non-routine audit would be a record that is examined during a triennial discipline review. In this case, most aspects of a designated analysis period are examined (superficially or in detail), and the documentation should include the notes or forms that were filled out by the reviewer. Non-routine audits are to be documented by filling out the Audit Template in RMS.

The INL Operator downloads the data logger files in comma-separated values (csv) format. The Analyst archives the .csv file on the INLPO server and uploads the file to Aquarius where it is set to working. The Analyst reviews the period of record, applies corrections to discrete water levels, examines the instantaneous values record, and edits it as needed. The initial instantaneous values cleanup includes checking thresholds set in the database and removing poor values such as spikes that were not automatically removed by thresholds. Water level data does not estimate missing instantaneous or daily values. When the Analyst has completed processing, the period of record is set to analyzed and they update the Station Analysis report for the period of analysis in the RMS. The Approver must be someone other than the operator/analyst that performs a quality-control check of the methods and procedures and verifies the accuracy and interpretations of the period of record. Any needed corrections are documented in RMS and returned to the Analyst. After verifying that corrections and edits are complete and evaluating hydrogragh comparisons, the period of record is approved in Aquarius and RMS. Water levels are reviewed and approved within a 2-month period after they are collected.

\section{Quality Assurance for Water Quality Activities}

The USGS Quality-Assurance Program at the INL Project Office incorporates the previously described methods of sample collection and processing with several other elements:

1. Analytical methods used by the laboratories;

2. quality-control samples and data-quality objectives;

3. review of analytical results of chemical constituents provided by the laboratories;

4. audits of performance in the field and in the laboratory;

5. corrective actions to resolve problems with field and laboratory methods;

6. reporting of data; and 
7. training and site safety requirements for personnel.

These elements are included to assure the following:

1. Reliability of the water-quality data;

2. Compatibility of the data with data collected by other organizations at the INL; and

3. Applicability of the data to the programmatic needs of the DOE, its contractors, and the scientific and regulatory communities.

\section{Analytical Methods and Quality-Control Samples}

Analytical methods used by the USGS NWQL for selected organic and inorganic constituents are described by Goerlitz and Brown (1972), Thatcher and others (1977), Skougstad and others (1979), Wershaw and others (1987), Fishman and Friedman (1989), Faires (1993), Fishman (1993), and Rose and Schroeder (1995). Additional publications that describe some analytical methods currently used at the USGS NWQL can be found at NWQL. Other analytical methods from the U.S. Environmental Protection Agency (USEPA) that are currently used at the USGS NWQL can be found at at the EPA website. Analytical methods from ASTM International that are currently used at the USGS NWQL can be found at http://www.astm.org. The type of analysis and the analytical procedure are specified on the USGS NWQL analytical services request form (fig. 4).

A discussion of procedures used by the RESL for the analysis of radionuclides in water is provided by Bodnar and Percival (1982) and the U.S. Department of Energy (1995). The type of analysis to be performed on a water sample is specified on the RESL sample submittal sheet (fig. $5)$.

A discussion of procedures and quality control used by NRF laboratories (Test America, GEL, and ARS International) is given in appendix 5. The laboratory request form for the NRF laboratories is given in figure 6 .

A detailed description of internal quality control and of the overall quality-assurance practices used by the USGS NWQL is provided by Friedman and Erdmann (1982) and Pritt and Raese (1995); quality-control practices at the laboratory are described by Jones (1987); and quality-assurance data for routine water analyses are presented in Maloney and others (1993, 2005) and Ludtke and others (2000). Quality-control samples collected by the INL Project Office includes collection and analysis of the following:

1. Duplicate samples - two or more samples collected concurrently or sequentially and sent to different laboratories;

2. Replicate samples - samples with the same sample identification numbers submitted to a laboratory;

3. Source solution blank samples - samples of deionized water, organic-free water, or inorganic-free water sent to a laboratory;

4. Equipment blanks - rinsate collected from bailers and thief samplers during decontamination procedures;

5. Field blanks, samples of deionized water, organic-free water, or inorganic-free water pored in bottles in the field;

6. Splits - large sample volumes divided into two or more equal volumes and sent to different laboratories for analysis;

7. Trip blanks - laboratory supplied samples of boiled deionized water that travel with water samples from time of collection to time of analysis; and 
8. Spiked samples - samples to which a known concentration of a constituent is added.

Generally, about 10 percent of the samples collected are dedicated to quality assurance. That is, for every 10 samples submitted to one of the laboratories for analysis, at least one is a replicate, a blank, a spike, or another type of quality-assurance sample. For samples that are to be analyzed for non-routine constituents, 15-20 percent of the samples are dedicated to quality assurance.

Comparative studies to determine agreement among analytical results for water-sample pairs analyzed by laboratories involved in the INL Project Office quality-assurance program are summarized by Wegner (1989), Williams (1996, 1997), Williams and others (1998), Knobel and others (1999), Carkeet and others (2001), Swanson and others (2002, 2003), Rattray and Campbell (2004), Rattray and others (2005), Rattray (2012), Davis and others (2013), Rattray (2014), Bartholomay and others (2015), Bartholomay and others (2017), and Bartholomay and others (2020). Additional quality-assurance studies by personnel at the INL Project Office include an evaluation of field-sampling and preservation methods for strontium-90 (Cecil and others, 1989), a comparison of different pump types used for sampling VOCs (Knobel and Mann, 1993), an analysis of tritium and strontium-90 concentrations in water from wells after purging different borehole volumes (Bartholomay, 1993), an analysis of the effect of different preservation methods on nutrient concentrations (Bartholomay and Williams, 1996), an analysis of two analytical methods for the determination of gross alpha- and beta-particle radioactivity (Bartholomay and others, 1999), and an evaluation of well-purging effects on water-quality of samples collected from the ESRPA (Knobel, 2006).

\section{Data-Quality Objectives}

Data-quality objectives are qualitative and quantitative criteria that describe the data needed by (1) managers or regulators to support environmental decisions and actions or (2) scientists to study natural or induced chemical processes in the eastern Snake River Plain aquifer. The first steps of the scientific method are somewhat analogous to, and supported by, dataquality objectives. Identifying problems is followed by hypothesizing solutions. Unbiased and thorough scientific experiments are proposed and then conducted, analyzed, and reported in the literature for peer review and use by others.

Laboratory data-quality objectives for routine water samples analyzed by the USGS NWQL are included in appendix 3, and data-quality objectives for radionuclides in water samples analyzed by the RESL are in appendix 4. Quality control requirements for GEL laboratories, LLC is given in appendix 5. Data-quality objectives for quality control data (includes both field and laboratory procedures for replicates and blanks) are included in appendix 6.

\section{Review of Analyses}

After the analytical results are obtained from the analyzing laboratory, the concentration of each constituent is reviewed by personnel at the INL Project Office for consistency, variability, and bias. Factors considered during the review are:

- The historical concentration of the solute at the site where the sample was collected;

- The concentration of the solute in replicate, split, blank, or other quality-assurance samples; 
- The concentrations of the solute in nearby wells that obtain water from the same aquifer or perched-water zone;

- A review of waste-disposal records and changes in disposal techniques, land use, and recharge that may influence the concentration of a solute(s);

- Cation-anion balance of analyses for which common ions are analyzed; and

- Other accepted tests for accuracy of analytical results, when appropriate (Hem, 1985, p. 163-165).

Constituents for which previous analyses have been made are reviewed for consistency with the first three factors. Under certain circumstances, a re-analysis by the laboratory is requested or a second sample is collected and analyzed to verify the concentration of the solute in the water. These circumstances include:

1. A constituent differs from historical data,

2. A constituent differs markedly from the concentrations in water from nearby wells, or

3. An initial analysis for a solute exceeds 80 percent of the maximum contaminant level (MCL) for that constituent set by the USEPA.

If resampling is necessary, replicates or split samples generally are collected to evaluate field and laboratory variability. Spiked and reference samples are used to measure bias. Constituents for which MCLs have been proposed or established are shown in tables 2-6.

If analytical results indicate that concentrations in samples from one site vary by more than 50 percent from historical record for no obvious reason, reruns are requested and the results are evaluated by replicate sampling during the next sample period. If the analytical results for the replicates do not agree, the source of the discrepancy is investigated.

Table 2. Maximum contaminant levels of types of radioactivity and selected radionuclides in water.

[The maximum contaminant levels were established pursuant to the recommendations of the U.S. Environmental Protection Agency (2020) for community water systems and are included for comparison purposes only. The maximum contaminant level given for gross alpha-particle radioactivity includes radium-226 but excludes radon and uranium. The maximum contaminant level given for gross beta-particle and gamma radioactivity excludes radioactivity from natural sources and is included for comparison purposes only. Maximum contaminant levels given for strontium-90 and tritium are average concentrations assumed to produce a total body or organ dose of 4 millirem per year of beta-particle radiation. Abbreviations: $\mathrm{mrem} / \mathrm{yr}$, millirem per year; $\mathrm{pCi} / \mathrm{L}$, picocurie per liter; $\mu \mathrm{g} / \mathrm{L}$, microgram per liter]

\begin{tabular}{lc}
\hline \multicolumn{1}{c}{ Radionuclide or type of radioactivity } & Maximum contaminant level \\
\hline Gross alpha-particle radioactivity & $15 \mathrm{pCi} / \mathrm{L}$ \\
Gross beta-particle and gamma radioactivity & $4 \mathrm{mrem} / \mathrm{yr}$ \\
Iodine-129 & $1 \mathrm{pCi} / \mathrm{L}$ \\
Strontium-90 & $8 \mathrm{pCi} / \mathrm{L}$ \\
Tritium & $20,000 \mathrm{pCi} / \mathrm{L}$ \\
Uranium & $30 \mu \mathrm{g} / \mathrm{L}$ \\
\hline
\end{tabular}


Table 3. Maximum contaminant levels, secondary maximum contaminant levels, and reporting levels of selected trace elements in water.

[The maximum contaminant levels are for total measurements and were established pursuant to the recommendations of the U.S. Environmental Protection Agency (2020) for community water systems and are for comparison purposes only. Secondary maximum contaminant levels - shown in brackets — are from U.S. Environmental Protection Agency (2020). The reporting levels are taken from the Laboratory Information Management System used by the National Water Quality Laboratory, U. S. Geological Survey. More than one reporting level is given for constituents analyzed by different schedules (see app. 1). Units are in micrograms per liter $(\mu \mathrm{g} / \mathrm{L})$. Symbols: MCL, maximum contaminant levels; -, maximum contaminant level has not been established; ${ }^{* 1}$, copper has as action level of $1,300 \mu \mathrm{g} / \mathrm{L} ;{ }^{* 2}$, lead has as action level of $15 \mu \mathrm{g} / \mathrm{L}$; SMCL secondary maximum contaminant levels]

\begin{tabular}{lcl}
\hline Trace element & MCL [SMCL] & Reporting level \\
\hline Aluminum & {$[50-200]$} & 3.0 \\
Antimony & 6 & 0.06 \\
Arsenic & 10 & 0.1 \\
Barium & 2,000 & $0.01 ; 0.6$ \\
Beryllium & 4 & 0.01 \\
Boron & - & 2.0 \\
Cadmium & 5 & 0.03 \\
Chromium & 100 & $1.0 ; 0.5$ \\
Cobalt & - & 0.03 \\
Copper & $* 1$ & 0.4 \\
Iron & {$[300]$} & 10 \\
Lead & $* 2$ & 0.02 \\
Lithium & - & 0.15 \\
Manganese & {$[50]$} & 0.4 \\
Mercury & 2 & 0.005 \\
Molybdenum & - & 0.05 \\
Nickel & - & 0.2 \\
Selenium & 50 & 0.05 \\
Silver & {$[100]$} & $0.03 ; 1.0$ \\
Strontium & - & 0.5 \\
Thallium & 2 & 0.04 \\
Uranium & 30 & 0.03 \\
Vanadium & - & 0.1 \\
Zinc & {$[5,000]$} & 2.0 \\
\hline & &
\end{tabular}


Table 4. Maximum contaminant levels, secondary maximum contaminant levels, and reporting levels of selected common ions in water.

[The maximum contaminant levels are for total measurements and were established pursuant to the recommendations of the U.S. Environmental Protection Agency (2020) for community water systems and are for comparison purposes only. Secondary maximum contaminant levels - shown in brackets - are from U.S. Environmental Protection Agency (2020). The reporting levels are taken from the Laboratory Information Management System used by the National Water Quality Laboratory, U. S. Geological Survey. Bromide's reporting level is based on the method detection level; others are based on long term method detection levels. Units are in milligrams per liter (mg/L). Abbreviations and symbols: MCL, maximum contaminant levels; SMCL, Secondary maximum contaminant levels; -, maximum contaminant level has not been established]

\begin{tabular}{lcc}
\hline \multicolumn{1}{c}{ Constituent } & $\begin{array}{c}\text { MCL } \\
{[S M C L]}\end{array}$ & Reporting level \\
\hline Bromide & - & 0.01 \\
Calcium & - & 0.022 \\
Chloride & {$[250]$} & 0.02 \\
Fluoride & $4.0[2.0]$ & 0.004 \\
Magnesium & - & 0.01 \\
Potassium & - & 0.3 \\
Silica & - & 0.05 \\
Sodium & - & 0.4 \\
Sulfate & {$[250]$} & 0.02 \\
\hline
\end{tabular}

Table 5. Maximum contaminant levels and reporting levels of selected nutrients in water.

[The maximum contaminant levels are for total measurements and were established pursuant to the recommendations of the U.S. Environmental Protection Agency (2020) for community water systems and are for comparison purposes only. The reporting levels are taken from the Laboratory Information Management System (LIMS) used by the National Water Quality Laboratory, U. S. Geological Survey. Reporting levels for nitrite and nitrite plus nitrate are based on method detection levels; others are based on long term method detection levels. Units are in milligrams per liter (mg/L). Symbol: -, maximum contaminant level has not been established]

\begin{tabular}{lrc}
\hline \multicolumn{1}{c}{ Constituent } & MCL & Reporting level \\
\hline Ammonia (as nitrogen) & - & 0.01 \\
Nitrite (as nitrogen) & 1 & 0.001 \\
Nitrite plus nitrate (as nitrogen) & 10 & 0.04 \\
Orthophosphate (as phosphorus) & - & 0.04 \\
\hline
\end{tabular}


Table 6. Maximum contaminant levels and minimum reporting levels of selected volatile organic compounds in water.

[Analyses performed by the U. S. Geological Survey National Water Quality Laboratory using an analytical method equivalent to U.S. Environmental Protection Agency method 524.2. MCL's were established pursuant to the recommendations of the U. S. Environmental Protection Agency (2020) for community water systems and are included for comparison purposes only. MRL's are from the Laboratory Information Management System (LIMS) used by the National Water Quality Laboratory, U. S. Geological Survey. Units are in micrograms per liter ( $\mu \mathrm{g} / \mathrm{L})$. Abbreviations: MCL, maximum contaminant level; MRL, minimum reporting level. Symbols: -, MCL has not been established or proposed; *, total trihalomethanes-which include bromoform, chlorodibromomethane, chloroform, and dichlorobromomethane-in community water systems serving 10,000 or more persons cannot exceed $80 \mu \mathrm{g} / \mathrm{L}$ (U.S. Environmental Protection Agency, 2020)]

\begin{tabular}{lrrlrr}
\hline \multicolumn{1}{c}{ Compound } & MCL & MRL & \multicolumn{1}{c}{ Compound } & MCL & MRL \\
\hline Acrylonitrile & - & 2.5 & Trichloroethylene (-ethene) & 5 & 0.1 \\
Benzene & 5 & 0.1 & Trichlorofluoromethane & - & 0.2 \\
Bromobenzene & - & 0.2 & Trichloromethane (Chloroform) & $*$ & 0.1 \\
Bromochloromethane & - & 0.2 & Vinyl chloride & 2 & 0.2 \\
Bromodichloromethane & $*$ & 0.2 & Xylenes, all isomers & 10,000 & 0.3 \\
Bromomethane & - & 0.3 & $1,1,1,2$-Tetrachloroethane & - & 0.2 \\
Butylbenzene & - & 0.2 & $1,1,1$-Trichloroethane & 200 & 0.1 \\
Chlorobenzene (mono-) & 100 & 0.1 & 1,1,2,2-Tetrachloroethane & - & 0.2 \\
Chloroethane & - & 0.2 & 1,1,2-Trichloroethane & 5 & 0.2 \\
Chloromethane & - & 0.2 & 1,1,2-Trichlorotrifluoroethane & - & 0.1 \\
cis-1,2-Dichloroethene (-ethylene) & 70 & 0.1 & 1,1-Dichloroethane & - & 0.1 \\
cis-1,3-Dichloropropene & - & 0.2 & 1,1-Dichloroethene (-ethylene) & 7 & 0.1 \\
Dibromochloromethane & $*$ & 0.2 & 1,1-Dichloropropene & - & 0.2 \\
Dibromomethane & - & 0.2 & 1,2,3-Trichlorobenzene & - & 0.2 \\
Dichlorodifluoromethane & - & 0.2 & 1,2,3-Trichloropropane & - & 0.2 \\
Dichloromethane & 5 & 0.2 & 1,2,4-Trichlorobenzene & 70 & 0.2 \\
Ethylbenzene & 700 & 0.1 & 1,2,4-Trimethylbenzene & - & 0.2 \\
Hexachlorobutadiene & - & 0.2 & 1,2-Dibromo-3-chloropropane & - & 0.5 \\
Isopropylbenzene & - & 0.2 & 1,2-Dibromoethane & - & 0.2 \\
Methyl tert-butyl ether (MTBE) & - & 0.2 & 1,2-Dichlorobenzene (ortho-) & 600 & 0.1 \\
n-Propylbenzene & - & 0.2 & 1,2-Dichloroethane & 5 & 0.2 \\
Naphthalene & - & 0.5 & 1,2-Dichloropropane & 5 & 0.1 \\
sec-Butylbenzene & - & 0.2 & 1,3,5-Trimethylbenzene & - & 0.2 \\
Styrene & 100 & 0.1 & 1,3-Dichlorobenzene & - & 0.1 \\
tert-Butylbenzene & - & 0.2 & 1,3-Dichloropropane & - & 0.2 \\
Tetrachloroethylene & 5 & 0.1 & 1,4-Dichlorobenzene (para-) & 75 & 0.1 \\
Tetrachloromethane (Carbon tet) & 5 & 0.2 & 2,2-Dichloropropane & - & 0.2 \\
Toluene & 1,000 & 0.2 & 2-Chlorotoluene & - & 0.2 \\
trans-1,2-Dichloroethylene & 100 & 0.1 & 4-Chlorotoluene & - & 0.2 \\
trans-1,3-Dichloropropene & - & 0.24 & 4-Isopropyl-1-methylbenzene & - & 0.2 \\
Tribromomethane (Bromoform) & $*$ & 0.2 & & & \\
\hline & & & & &
\end{tabular}




\section{Performance Audits}

Performance audits are conducted routinely at three levels: (1) at the field level, (2) at the laboratory level, and (3) through National Field Quality-Assurance Tests. At the field level, the Project Chief or a designee routinely accompanies the field personnel to a selected number of sites to ascertain whether proper field techniques are used to collect and preserve the samples; to ensure that proper safety procedures are followed; and, when necessary, to evaluate the training of new employees. The field auditor's checklist is shown in appendix 8. Written results of the field audits are provided to the employee, and copies of the field audits are stored in the office quality-assurance files on the server. Performance audits at the laboratory level are done in compliance with the process outlined in the individual laboratories quality assurance manuals or procedures.

The USGS INL Project Office participates in the National Field Quality-Assurance Program established by the USGS to evaluate the accuracy of water-quality field measurements. Quality-assurance blind samples are sent to field personnel for testing. The results are sent back to the water-quality service unit for evaluation. If field personnel or equipment do not pass the test, corrective action is taken. The program is described in detail by Erdmann and Thomas (1985).

In addition to the routine performance audits, water-quality activities at the INL Project Office are periodically monitored and reviewed by other USGS personnel: the Water-Quality Specialist for the USGS Idaho Water Science Center, Boise, Idaho; and personnel at the Office of Quality Assurance. Reviews by personnel at the USGS Idaho Water Science Center take place at 1-2-year intervals; reviews by the Office of Quality Assurance take place at 3-4-year intervals. The reviews are summarized in writing, and the reports are distributed to the USGS INL Project Office, Idaho Water Science Center and to the Office of Quality Assurance. If deficiencies are documented, the Chief of the USGS INL Project Office must submit a written reply outlining the necessary corrective action.

\section{Corrective Actions}

If the performance audits indicate inconsistencies or inadequacies in field methods or in analytical results by the laboratories, the problems are documented, and the field personnel or laboratories are notified in writing of the inconsistencies or inadequacies. Training is provided to the field personnel as needed, and the frequency of performance audits is increased until the performance is judged by the USGS INL Project Office Chief to be suitable and consistent with written guidelines.

Inconsistencies and inadequacies in laboratory analyses are discussed with or submitted in writing to the appropriate laboratory director, who is responsible for initiating the appropriate action to resolve the problem. To evaluate whether appropriate actions are taken, the frequency and numbers of replicate, blank, split, or other quality-assurance samples are increased until it is demonstrated that problems in the laboratory methods are resolved.

If USGS INL Project Office personnel discover a problem with sampling procedures, well integrity, equipment calibration, or data review analysis and interpretation that cannot be resolved at the project level, the USGS Idaho Water Science Center Water-Quality Specialist is notified of the problem. If the specialist cannot resolve the problem in consultation with the USGS Office of Quality Assurance, the problem may be referred to the USGS's research hydrologists and chemists who may be able to aid in resolving the problem. 


\section{Reporting of Data}

All data collected by the USGS INL Project Office are publically available, after review, and most data are published in data reports and used in interpretive reports. Water-quality information, subsequent to its review, is entered into the NWIS and periodically merged with a nationally-accessible database. Data that suggest a possible human health or environmental problem are provided to managerial agencies such as the DOE and to regulatory agencies, such as the State of Idaho's Department of Environmental Quality and the USEPA, Region 10. After data have been reviewed and verified - by resampling if necessary - they are available to the general public either upon request or through the USGS National Water Information System Web portal at https://waterdata.usgs.gov/nwis.

\section{Quality Assurance for Water-Level Measurements}

Routine measurements are collected with a calibrated e-tape and are checked by taking two readings that need to be within $+/-0.02 \mathrm{ft}$ of each other. While in the field, the final measurement is compared to historic measurements to ensure the readings that are taken are reasonable. If the readings don't seem reasonable, a measurement is retaken. Well integrity for wells measured routinely are checked with downhole video and geophysical logs whenever pumps are pulled.

MLMS pressure measurements are checked at each site by taking a second pressure reading from two duplicate ports after all the first pressure readings have been taken from the ports. Historical pressure readings are reviewed in the field to assure probe location and accurate readings are collected.

\section{Training Requirements and Site Safety}

Training and site safety are important components of the USGS INL Project Office QAP. Employees are not assigned tasks for which they are not adequately trained, and all employees have a stop-work authority if they feel that work conditions are unsafe. The responsibility for ensuring that employees are adequately trained is shared jointly by the employee and the employee's supervisor. A more detailed description of USGS INL Project Office personnel training requirements and site safety requirements are given in the USGS INL Site Safety and Job Hazard Analysis Document (R. Bartholomay, USGS, December 2020, written commun.).

USGS INL Project Office personnel are called on from time to time to sample or measure wells for which no USGS-collected data are available. When this situation occurs, an effort will be made to ascertain if samples have been collected by other environmental monitoring programs to determine if there is any potential health risk to sample-collection personnel or laboratoryanalysis personnel. To minimize the risk of contaminating low-level environmental laboratories, the laboratory analytical request form and the sample bottles will be noted as containing either samples with unknown or expected concentrations of contaminants that are potentially large. 


\section{Selected References}

Bartholomay, R.C., 1993, Concentrations of tritium and strontium-90 in water from selected wells at the Idaho National Engineering Laboratory after purging one, two, and three bore-hole volumes: U.S. Geological Survey Water Resources Investigations Report 93-4201 (DOE/ID22111), 21 p., https://doi.org/10.3133/wri934201.

Bartholomay, R.C., Hill, G.H., and Randolph, R.B., 1999, Statistical comparison of gross alphaand gross beta-particle activity in water analyzed using two analytical methods [abs.]: Rocky Mountain Conference on Analytical Chemistry, 41st, Denver, Colorado, 1999 Program and Abstracts, p. 132.

Bartholomay, R.C., Hopkins, C.B., and Maimer, N.V., 2015, Chemical constituents in groundwater from multiple zones in the eastern Snake River Plain aquifer, Idaho National Laboratory, Idaho, 2009-2013: U.S. Geological Survey Scientific Investigations Report 20155002 (DOE/ID-22232), 110 p. [Also available at https://doi.org/10.3133/sir20155002.]

Bartholomay, R.C., Knobel, L.L., and Rousseau, J.P., 2003, Field methods and quality-assurance plan for quality-of-water activities, U.S. Geological Survey, Idaho National Engineering and Environmental Laboratory, Idaho: U.S. Geological Survey Open-File Report 03-42 (DOE/ID22182), 45 p. [Also available at https://pubs.er.usgs.gov/publication/ofr0342.]

Bartholomay, R.C., Maimer, N.V., Rattray, G.W., and Fisher, J.C., 2017, An update of hydrologic conditions and distribution of selected constituents in water, eastern Snake River Plain aquifer and perched groundwater zones, Idaho National Laboratory, Idaho, emphasis 2012-15: U.S. Geological Survey Scientific Investigations Report 2017-5021 (DOE/ID22242), 87 p. [Also available at https://doi.org/10.3133/sir20175021.]

Bartholomay, R.C., Maimer, N.V., Rattray, G.W., and Fisher, J.C., 2020, An update of hydrologic conditions and distribution of selected constituents in water, eastern Snake River Plain aquifer and perched groundwater zones, Idaho National Laboratory, Idaho, emphasis 2016-18: U.S. Geological Survey Scientific Investigations Report 2019-5149 (DOE/ID22251), 82 p. [Also available at https://doi.org/10.3133/sir20195149.]

Bartholomay, R.C., Maimer, N.V., and Wehnke, A.J., 2014, Field methods and quality-assurance plan for water-quality activities and water-level measurements: U.S. Geological Survey OpenFile Report 2014-1146 (DOE/ID-22230) 66 p. [Also available at https://doi.org/10.3133/ofr20141146.]

Bartholomay, R.C., and Williams, L.M., 1996, Evaluation of preservation methods for selected nutrients in ground water at the Idaho National Engineering Laboratory, Idaho: U.S. Geological Survey Water-Resources Investigations Report 96-4260 (DOE/ID-22131), 16 p. [Also available at https://doi.org/10.3133/wri964260.]

Bodnar, L.Z., and Percival, D.R., eds., 1982, Analytical Chemistry Branch procedures manualRadiological and Environmental Sciences Laboratory: U.S. Department of Energy Report IDO-12096 [variously paged].

Carkeet, C., Rosentreter, J.J., Bartholomay, R.C., and Knobel, L.L., 2001, Geochemistry of the Big Lost River drainage basin, Idaho: U.S. Geological Survey Water-Resources Investigations Report 01-4031 (DOE/ID-22174), 31 p. [Also available at https://doi.org/10.3133/wri014031.] Cecil, L.D., Knobel, L.L., Wegner, S.J., and Moore, L.L., 1989, Evaluation of field sampling and preservation methods for strontium-90 in ground water at the Idaho National Engineering Laboratory, Idaho: U.S. Geological Survey Water-Resources Investigations Report 89-4146 (DOE/ID-22083), 24 p. [Also available at https://doi.org/10.3133/wri894146.] 
Childress, C.J.O., Forman, W.T., Connor, B.F., and Maloney, T.J., 1999, New reporting procedures based on long-term method detection levels and some considerations for interpretations of water-quality data provided by the U.S. Geological Survey National Water Quality Laboratory: U.S. Geological Survey Open-File Report 99-193, 19 p. [Also available at https://doi.org/10.3133/ofr99193.].

Claassen, H.C., 1982, Guidelines and techniques for obtaining water samples that accurately represent the water chemistry of an aquifer: U.S. Geological Survey Open-File Report 821024, 49 p. [Also available at https://doi.org/10.3133/ofr821024.].

Cunningham, W.L., and Schalk, C.W., comps., 2011, Groundwater technical procedures of the U.S. Geological Survey: U.S. Geological Survey Techniques and Methods 1-A1, 151 p. [Also available at https://pubs.usgs.gov/tm/1a1/.]

Currie, L.A., 1968, Limits for qualitative detection and quantitative determination-Application to radiochemistry: Analytical Chemistry, v. 40, no. 3, p. 586-593.

Davis, L.C., Bartholomay, R.C., and Rattray, G.W., 2013, An update of hydrologic conditions and distribution of selected constituents in water, eastern Snake River Plain aquifer and perched groundwater zones, Idaho National Laboratory, Idaho emphasis 2009-11: U.S. Geological Survey Scientific Investigations Report 2013-5214, (DOE/ID-22226), 90 p. [Also available at https://doi.org/10.3133/sir20135214.]

Erdmann, D.E., and Thomas, J.D., 1985, Quality assurance of the U.S. Geological Survey waterquality field measurements, in Taylor, J.K., and Stanley, T.W., eds., Quality assurance for environmental measurements-American Society for Testing and Materials Special Technical Testing Publication 867 p. 110-115.

Faires, L.M., 1993, Methods of analysis by the U.S. Geological Survey National Water Quality Laboratory-Determination of metals in water by inductively coupled plasma-mass spectrometry: U.S. Geological Survey Open-File Report 92-634, 28 p. [Also available at https://doi.org/10.3133/ofr92634.].

Fisher, J.C., and Twining, B.V., 2011, Multilevel groundwater monitoring of hydraulic head and temperature in the eastern Snake River Plain aquifer, Idaho National Laboratory, Idaho, 200708: U.S. Geological Survey Scientific Investigations Report 2010-5253, DOE/ID-22213, 62 p. [Also available at https://doi.org/10.3133/sir20105253.]

Fishman, M.J., ed., 1993, Methods of analysis by the U.S. Geological Survey National Water Quality Laboratory-Determination of inorganic and organic constituents in water and fluvial sediments, U.S. Geological Survey Open-File Report, 217 p. [Also available at https://doi.org/10.3133/ofr93125.].

Fishman, M.J., and Friedman, L.C., 1989, Methods for determination of inorganic substances in water and fluvial sediments: U.S. Geological Survey Techniques of Water-Resources Investigations, book 5, chap. Al, 545 p. [Also available at https://doi.org/10.3133/twri05A1.]

Friedman, L.C., and Erdmann, D.E., 1982, Quality assurance practices for the chemical and biological analyses of water and fluvial sediments: U.S. Geological Survey Techniques of Water-Resources Investigations, book 5, chap. A6, 181 p. [Also available at https://doi.org/10.3133/twri05A6.]

Garbarino, J.R., 2000, Methods of analysis by the U.S. Geological Survey National Water Quality Laboratory-Determination of whole-water recoverable arsenic, boron, and vanadium using inductively coupled plasma-mass spectrometry: U.S. Geological Survey Open-File Report 99-464, 15 p. [Also availalbe at https://doi.org/10.3133/ofr99464.], https://nwql.usgs.gov/pubs/OFR/OFR-99-464.pdf 
Garbarino, J.R., and Damrau, D.L., 2001, Methods of analysis by the U.S. Geological Survey National Water Quality Laboratory-Determination of organic plus inorganic mercury in filtered and unfiltered natural water with cold vapor-Automatic fluorescence spectrometry: U.S. Geological Survey Water-Resources Investigations Report 01-4132, 16 p. [Also available at https://doi.org/10.3133/wri014132.].

Garbarino, J.R., and Hoffman, G.L., 1999, Methods of analysis by the U.S. Geological Survey National Water Quality Laboratory - Comparison of a nitric acid in-bottle digestion procedure to other whole-water digestion procedures: U.S. Geological Survey Open- File Report 99-094, $21 \mathrm{p}$.

Garbarino, J.R., and Struzeski, T.M., 1998, Methods of analysis by the U.S. Geological Survey National Water Quality Laboratory-Determination of elements in whole-water digests using inductively coupled plasma-optical emission spectrometry and inductively coupled plasmamass spectrometry: U.S. Geological Survey Open-File Report 98-165, 101 p. [Also available at https://doi.org/10.3133/ofr98165.].

Laboratories, G.E.L., LLC, 2015, GEL Laboratories, LLC quality assurance plan, revision 29, 110 p., accessed on 11/23/20 at https://www.nrc.gov/docs/ML1629/ML16293A187.pdf

Goerlitz, D.F., and Brown, Eugene, 1972, Methods for analysis of organic substances in water: U.S. Geological Survey Techniques of Water Resources Investigations, book 5, chap. A3, 40 p. [Also available at https://doi.org/10.3133/twri05A3_1972.]

Hardy, M.A., Leahy, P.P., and Alley, W.M., 1989, Well installation and documentation and ground-water sampling protocols for the pilot National Water-Quality Assessment Program: U.S. Geological Survey Open-File Report 89-396, 36 p. [Also available at https://doi.org/10.3133/ofr89396.].

Hem, J.D., 1985, Study and interpretation of chemical characteristics of natural water: U.S. Geological Survey Water-Supply Paper 2254, 264 p., https://pubs.er.usgs.gov/publication/wsp2254

Jones, B.E., 1987, Quality control manual of the U.S. Geological Survey's National Water Quality Laboratory: U.S. Geological Survey Open-File Report 87-457, 17 p. [Also available at https://doi.org/10.3133/ofr87457.].

Knobel, L.L., 2006, Evaluation of well-purging effects on water-quality results for samples collected from the eastern Snake River Plain aquifer underlying the Idaho National Laboratory, Idaho: U.S. Geological Survey Scientific Investigations Report 2006-5232 (DOE/ID-22200), 52 p. [Also available at https://pubs.usgs.gov/sir/2006/5232/.]

Knobel, L.L., Bartholomay, R.C., Tucker, B.J., Williams, L.M., and Cecil, L.D., 1999, Chemical constituents in ground water from 39 selected sites with an evaluation of associated quality assurance data, Idaho National Engineering and Environmental Laboratory and vicinity, Idaho: U.S. Geological Survey Open-File Report 99-246 (DOE/ID-22159), 58 p. [Also available at https://doi.org/10.3133/ofr99246.]

Knobel, L.L., and Mann, L.J., 1993, Sampling for volatile organic compounds using positivedisplacement piston and centrifugal submersible pumps-A comparative study: Ground Water Monitoring Review, v. 13, no. Spring, p. 142-148.

Knobel, L.L., Tucker, B.J., and Rousseau, J.P., 2008, Field methods and quality-assurance plan for quality-of-water activities, U.S. Geological Survey, Idaho National Laboratory, Idaho: U.S. Geological Survey Open-File Report 2008-1165 (DOE/ID-22206), 36 p. [Also available at https://pubs.usgs.gov/of/2008/1165/.] 
Ludtke, A.S., Woodworth, M.T., and Marsh, P.S., 2000, Quality-assurance results for routine water analyses in U.S. Geological Survey Laboratories, water year 1998: U.S. Geological Survey Water-Resources Investigations Report 00-4176, 198 p. [Also available at https://10.3133/wri20004176.].

Maloney, T.J., ed., 2005, Quality management system-U.S. Geological Survey National Water Quality Laboratory: U.S. Geological Survey Open-File Report 2005-1263 (version 1.3), variously paged. [Also available at https://pubs.usgs.gov/of/2005/1263/.]

Maloney, T.J., Ludtke, A.S., and Krizman, T.L., 1993, Quality assurance for routine water analysis in the laboratories of the U.S. Geological Survey for water year 1990: U.S. Geological Survey Water-Resources Investigations Report 93-4082, 145 p. [Also available at https://10.3133/wri934082.].

Mann, L.J., 1996, Quality-assurance plan and field methods for quality-of-water activities, U.S. Geological Survey, Idaho National Engineering Laboratory, Idaho: U.S. Geological Survey Open-File Report 96-615 (DOE/ID 22132), 37 p. [Also available at https://doi.org/10.3133/ofr96615.]

Pritt, J.W., 1989, Quality assurance of sample containers and preservatives at the U.S. Geological Survey National Water Quality Laboratory, in Pederson, G.L., and Smith, M.M., compilers, U.S. Geological Survey Second National Symposium on Water Quality-Abstracts of the technical sessions: U.S. Geological Survey Open-File Report 89-409, 111 p. [Also available at https://doi.org/10.3133/ofr89409.]

Pritt, J.W., and Raese, J.W., eds., 1995, Quality assurance/quality control manual-National Water Quality Laboratory: U.S. Geological Survey Open-File Report 95-443, 35 p. [Also available at https://doi.org/10.3133/ofr95443.]

Rattray, G.W., 2012, Evaluation of quality-control data collected by the U.S. Geological Survey for routine water-quality activities at the Idaho National Laboratory, Idaho, 1996-2001: U.S. Geological Survey Scientific Investigations Report 2012-5270 (DOE/ID-22222), 74 p. [Also available at https://doi.org/10.3133/sir20125270.]

Rattray, G.W., 2014, Evaluation of quality-control data collected by the U.S. Geological Survey for routine water-quality activities at the Idaho National Laboratory, Idaho, 2002-2008: U.S. Geological Survey Scientific Investigations Report 2014-5027, (DOE/ID-22228), 66 p. [Also available at https://doi.org/10.3133/sir20145027.]

Rattray, G.W., and Campbell, L.J., 2004, Radiochemical and chemical constituents in water from selected wells and springs from the southern boundary of the Idaho National Engineering and Environmental Laboratory to the Hagerman area, Idaho, 2002: U.S. Geological Survey OpenFile Report 2004-1004 (DOE/ID-22190), 22 p. [Also available at https://pubs.usgs.gov/of/2004/1004/.]

Rattray, G.W., Wehnke, A.J., Hall, L.F., and Campbell, L.J., 2005, Radiochemical and chemical constituents in water from selected wells and springs from the southern boundary of the Idaho National Laboratory to the Hagerman area, Idaho, 2003: U.S. Geological Survey Open-File Report 2005-1125 (DOE/ID-22193), 25 p. [Also available at https://pubs.usgs.gov/of/2005/1125/.]

Rose, D.L., and Schroeder, M.P., 1995, Methods of analysis by the U.S. Geological Survey National Water Quality Laboratory-Determination of volatile organic compounds in water by purge and trap capillary gas chromatography/mass spectrometry: U.S. Geological Survey Open-File Report 94-708, 26 p. [Also available at https://doi.org/10.3133/ofr94708W.]. 
Skougstad, M.W., Fishman, M.J., Friedman, L.C., Erdmann, D.E., and Duncan, S.S., 1979, Methods for determination of inorganic substances in water and fluvial sediments: U.S. Geological Survey Techniques of Water-Resources Investigations, book 5, chap. A1, 626 p. [Also available at https://doi.org/10.3133/twri05A1_1979.]

Stevens, H.H., Jr., Ficke, J.F., and Smoot, G.F., 1975, Water temperature-Influential factors, field measurement, and data presentation: U.S. Geological Survey Techniques of WaterResources Investigations, book 5, chap. D1, 65 p. [Also available at https://pubs.usgs.gov/twri/twri1-d1/html/pdf.html.]

Swanson, S.A., Rosentreter, J.J., Bartholomay, R.C., and Knobel, L.L., 2002, Geochemistry of the Little Lost River drainage basin, Idaho: U.S. Geological Survey Water-Resources Investigations Report 02-4120 (DOE/ID-22179), 29 p. [Also available at https://doi.org/10.3133/wri024120.]

Swanson, S.A., Rosentreter, J.J., Bartholomay, R.C., and Knobel, L.L., 2003, Geochemistry of the Birch Creek drainage basin, Idaho: U.S. Geological Survey Water-Resources Investigations Report 03-4272 (DOE/ID-22188), 36 p. [Also available at https://doi.org/10.3133/wri034272.]

TestAmerica Laboratories, 2013, Quality assurance manual: Document No. TALDenver QAM rev. 5,165 p.

Thatcher, L.L., Janzer, V.J., and Edwards, K.W., 1977, Methods for determination of radioactive substances in water and fluvial sediments: U.S. Geological Survey Techniques of WaterResources Investigations, book 5, chap. A5, 95 p.

Timme, P.J., 1995, National Water Quality Laboratory, 1995 services catalog: U.S. Geological Survey Open-File Report 95-352, 120 p. [Also available at https://doi.org/10.3133/ofr95352.]. U.S. Department of Energy, 1995, Radiochemistry manual, revision 10: Idaho Falls, Idaho, U.S. Department of Energy, Radiological and Environmental Sciences Laboratory, variously paged.

U.S. Environmental Protection Agency, 1994, Guidance for the data quality objectives process: U.S. Environmental Protection Agency Report No. 600R-96/005, variously paged.

U.S. Environmental Protection Agency, 1987, Annual Report, fiscal year 1986-Methods validation report (radiation): U.S. Environmental Protection Agency Report No. EPA/600/X$87 / 128,55 \mathrm{p}$.

U.S. Environmental Protection Agency, 2020, Protection of environment, Code of Federal Regulations 40: Office of the Federal Register, National Archives and Records Administration, p. 136-149, https://ecfr.io/Title-40/cfrv25\#0

U.S. Geological Survey, variously dated, National field manual for the collection of waterquality data: U.S. Geological Survey Techniques of Water-Resources Investigations, book 9, chaps. A1-A9 [Also available at https://pubs.water.usgs.gov/twri9A.]

Wegner, S.J., 1989, Selected quality assurance data for water samples collected by the U.S. Geological Survey, Idaho National Engineering Laboratory, 1980 to 1988: U.S. Geological Survey Water-Resources Investigations Report 89-4168 (DOE/ID-22085), 91 p. [Also available at https://doi.org/10.3133/wri894168.]

Wershaw, R.L., Fishman, M.J., Grabbe, R.R., and Lowe, L.E., 1987, Methods for the determination of organic substances in water and fluvial sediments: U.S. Geological Survey Techniques of Water-Resources Investigations, book 5, chap. A3, 80 p. [Also available at https://doi.org/10.3133/twri05A3.]

Williams, L.M., 1996, Evaluation of quality assurance/quality control data collected by the U.S. Geological Survey for water-quality activities at the Idaho National Engineering Laboratory, 
Idaho, 1989 through 1993: U.S. Geological Survey Water-Resources Investigations Report 964148 (DOE/ID-22129), 116 p. [Also available at https://doi.org/10.3133/wri964148.]

Williams, L.M., 1997, Evaluation of quality assurance/quality control data collected by the U.S. Geological Survey for water-quality activities at the Idaho National Engineering Laboratory, Idaho, 1994 through 1995: U.S. Geological Survey Water-Resources Investigations Report 974058 (DOE/ID-22136), 87 p. [Also available at https://doi.org/10.3133/wri974058.]

Williams, L.M., Bartholomay, R.C., and Campbell, L.J., 1998, Evaluation of qualityassurance/quality control data collected by the U.S. Geological Survey from wells and springs between the southern boundary of the Idaho National Engineering and Environmental Laboratory and the Hagerman area, Idaho, 1989 through 1995: U.S. Geological Survey WaterResources Investigations Report 98-4206 (DOE/ID-22150), 83 p. [Also available at https://doi.org/10.3133/wri984206.]

Wood, W.W., 1981, Guidelines for collection and field analysis of ground-water samples for selected unstable constituents: U.S. Geological Survey Techniques of Water-Resources Investigations, book 1, chap. D2, 24 p. [Also available at https://pubs.er.usgs.gov/publication/twri01D2.] 


\section{Appendix 1. Field Schedule Showing Well and Pump Information and Sampling Schedules for Selected Wells and Streamflow Sites}

Table 1.1. Field schedule showing well and pump information and sampling schedules for selected wells and streamflow sites.

[Abbreviations and symbols: NRF, Naval Reactor Facility; gpm, gallon per minute; <, indicates the diameter is less than the hole depth indicated; >, indicates the diameter is greater than the hole depth indicated; -, not applicable]

\begin{tabular}{|c|c|c|c|c|c|c|c|c|}
\hline \multirow{2}{*}{$\begin{array}{c}\text { Local } \\
\text { site } \\
\text { identifier }\end{array}$} & \multirow{2}{*}{$\begin{array}{c}\text { Method } \\
\text { of } \\
\text { sampling }\end{array}$} & \multirow{2}{*}{$\begin{array}{c}\text { Hole } \\
\text { diameter } \\
\text { (inches) }\end{array}$} & \multirow{2}{*}{$\begin{array}{c}\text { Well } \\
\text { depth } \\
\text { (feet) }\end{array}$} & \multicolumn{2}{|c|}{$\begin{array}{c}\text { Analysis type } \\
\text { (see code) }\end{array}$} & \multirow{2}{*}{$\begin{array}{c}\text { Westbay } \\
\text { Code; zone }\end{array}$} & \multicolumn{2}{|c|}{$\begin{array}{c}\text { NRF } \\
\text { (see code) }\end{array}$} \\
\hline & & & & April & October & & May & November \\
\hline$\overline{\text { ANP } 6}$ & Pump 25 gpm & 10 & 295 & - & 5 & - & - & - \\
\hline ARA-MON-A-002 & Pump 15 gpm & 6 & 620 & - & 19 & - & - & - \\
\hline AREA 2 & Pump 18 gpm & 16 & 876 & - & 5 & - & - & - \\
\hline BLR (near Mackay) & Surface water & - & - & - & 3 & - & - & - \\
\hline BLR (INEL Div. $)^{1}$ & Surface water & - & - & 3 & - & - & - & - \\
\hline Birch Creek $^{1}$ & Surface water & - & - & - & 1 & - & - & - \\
\hline CFA $1^{1}$ & Pump 1,000 gpm & 16 & 639 & 10 & & - & - & - \\
\hline CFA $2^{1}$ & Pump 1,400 gpm & 16 & 681 & - & 10 & - & - & - \\
\hline CFA LF 2-10 & Pump 8.3 gpm & 6 & 716 & 20 & - & - & - & - \\
\hline CPP 1 & Pump 3000 gpm & 16 & 586 & 18 & - & - & - & - \\
\hline Cross Road ${ }^{1}$ & Pump 35 gpm & 8 & 796 & 19 & - & - & - & - \\
\hline CWP 1 & Bail & 6 & 58 & 4 & - & - & - & - \\
\hline CWP 8 & Bail & 6 & 63.5 & 4 & - & - & - & - \\
\hline GIN 2 & Pump 2 gpm & 2 & 381 & - & 24 & - & - & - \\
\hline Highway $3^{1,3}$ & Spigot & 8 & 750 & - & 22 & - & - & - \\
\hline 1ICPP-MON-A-166 & Pump 20 gpm & 6 & 527 & 14 & & - & - & - \\
\hline ICPP-MON-V-200 & Pump 4 gpm & 6 & 127 & - & 14 & - & - & - \\
\hline Little Lost River & Surface water & - & - & - & 1 & - & - & - \\
\hline MTR Test & Pump 26 gpm & 8 & 588 & 8 & & - & - & - \\
\hline Mud Lake ${ }^{1}$ & Surface water & - & - & - & 1 & - & - & - \\
\hline Middle $2050 \mathrm{~A}^{5}$ & Multi-depth thief sampler & (6) & 1,376 & - & - & 19 ; zone 15 & - & - \\
\hline Middle $2051^{1,5}$ & Multi-depth thief sampler & (6) & 1,177 & - & - & 19 ; zones 3,9 & - & - \\
\hline $\begin{array}{l}\text { No Name } 1 \text { (Tan } \\
\text { Expl.) }\end{array}$ & Pump 42 gpm & 12 & 550 & 24 & - & - & - & - \\
\hline NRF 3 & Pump 28 gpm & 16 & 546 & - & - & - & 32 & 34 \\
\hline NRF $6^{1}$ & Pump 30 gpm & 8 & 417 & - & - & - & 32 & 34 \\
\hline NRF 7 & Pump $2.5 \mathrm{gpm}^{4}$ & 10 & 417 & - & - & - & 31 & 33 \\
\hline NRF 8 & Pump 30 gpm & 8 & 423 & - & - & - & 32 & 34 \\
\hline NRF $9^{1}$ & Pump 30 gpm & 8 & 422 & - & - & - & 32 & 34 \\
\hline NRF 10 & Pump 30 gpm & 8 & 427 & - & - & - & 32 & 34 \\
\hline NRF $11^{1}$ & Pump 30 gpm & 8 & 417 & - & - & - & 32 & 34 \\
\hline NRF $12^{1}$ & Pump 30 gpm & 8 & 421 & - & - & - & 32 & 34 \\
\hline NRF 14 & Pump 25 gpm & 10 & 550 & - & - & - & 32 & 34 \\
\hline NRF 16 & Pump 25 gpm & 5 & 422 & - & - & - & 32 & 34 \\
\hline NPR Test & Pump 28 gpm & 6 & 600 & - & 19 & - & - & - \\
\hline PBF-MON-A-003 & Pump 10 gpm & 5 & 575 & - & 19 & - & - & - \\
\hline $\mathrm{P}$ and $\mathrm{W} 2^{1}$ & Pump 35 gpm & 10 & 378 & 19 & - & - & - & - \\
\hline PW-8 & Pump 8 gpm & 6 & 166 & 13 & - & - & - & - \\
\hline PW-91 & Bail & 6 & 200 & - & 13 & - & - & - \\
\hline Rifle Range & Pump 25 gpm & 5 & 620 & - & 14 & - & - & - \\
\hline RWMC M3S & Pump 6 gpm & 6 & 633 & - & 17 & - & - & - \\
\hline RWMC M7S & Pump 6 gpm & 6 & 628 & - & 17 & - & - & - \\
\hline
\end{tabular}




\begin{tabular}{|c|c|c|c|c|c|c|c|c|}
\hline \multirow{2}{*}{$\begin{array}{c}\text { Local } \\
\text { site } \\
\text { identifier }\end{array}$} & \multirow{2}{*}{$\begin{array}{l}\text { Method } \\
\text { of } \\
\text { sampling }\end{array}$} & \multirow{2}{*}{$\begin{array}{c}\text { Hole } \\
\text { diameter } \\
\text { (inches) }\end{array}$} & \multirow{2}{*}{$\begin{array}{l}\text { Well } \\
\text { depth } \\
\text { (feet) }\end{array}$} & \multicolumn{2}{|c|}{$\begin{array}{c}\text { Analysis type } \\
\text { (see code) }\end{array}$} & \multirow{2}{*}{$\begin{array}{c}\text { Westbay } \\
\text { Code; zone }\end{array}$} & \multicolumn{2}{|c|}{$\begin{array}{c}\text { NRF } \\
\text { (see code) }\end{array}$} \\
\hline & & & & April & October & & May & November \\
\hline RWMC M12S & Pump 6 gpm & 6 & 572 & - & 19 & - & - & - \\
\hline RWMC M14S & Pump $6 \mathrm{gpm}$ & 6 & 635 & - & 19 & - & - & - \\
\hline RWMC Production ${ }^{1,2}$ & Pump 200 gpm & $\begin{array}{l}10<658 \\
14>658\end{array}$ & 685 & - & 17 & - & - & - \\
\hline Site 4 & Pump 500 gpm & 8 & 495 & 7 & - & - & - & - \\
\hline Site 6 & Pump 30 gpm & 10 & 523 & & - & - & 32 & 34 \\
\hline Site 9 & Pump 25 gpm & 10 & 1,057 & 10 & - & - & & \\
\hline Site 17 & Pump 25 gpm & 15 & 600 & 5 & - & - & 32 & 34 \\
\hline SPERT 1 & Pump 400 gpm & 14 & 653 & 6 & & - & - & - \\
\hline TAN 2271 & Pump $1 \mathrm{gpm}$ & 10 & 282 & - & 24 & - & - & - \\
\hline TAN 2312 & Pump $27 \mathrm{gpm}$ & 10 & 522 & - & 24 & - & - & - \\
\hline TRA 3 & Pump 3,800 gpm & 20 & 602 & - & 8 & - & - & - \\
\hline TRA Disp. & Pump 25 gpm & $\begin{array}{l}8<1,114 \\
6>1,114\end{array}$ & 1267 & - & 14 & - & - & - \\
\hline W.S. for INEL-1 & Pump 30 gpm & 6 & 490 & 7 & - & - & - & - \\
\hline USGS 1 & Pump 15 gpm & 5 & 630 & - & 19 & - & - & - \\
\hline USGS 2 & Pump 16 gpm & 5 & 699 & 5 & - & - & - & - \\
\hline USGS 5 & Pump $3 \mathrm{gpm}^{4}$ & 6 & 494 & 26 & - & - & - & - \\
\hline USGS 7 & Pump 45 gpm & $\begin{array}{l}6<760 \\
4>760\end{array}$ & 903 & 24 & - & - & - & - \\
\hline USGS $8^{1}$ & Pump 15 gpm & 6 & 812 & 19 & - & - & - & - \\
\hline USGS 9 & Pump 15 gpm & 6 & 654 & - & 19 & - & - & - \\
\hline USGS $11^{1,3}$ & Pump 23 gpm & 6 & 704 & 19 & - & - & - & - \\
\hline USGS 12 & Pump 30 gpm & 10 & 563 & 11 & - & - & 32 & 34 \\
\hline USGS $14^{1,3}$ & Pump 16 gpm & 5 & 751 & - & 2 & - & - & - \\
\hline USGS 17 & Pump 30 gpm & $\begin{array}{l}6<365 \\
5>365\end{array}$ & 498 & 19 & - & - & - & - \\
\hline USGS $18^{1}$ & Pump 30 gpm & 4 & 329 & 5 & - & - & - & - \\
\hline USGS $19^{1}$ & Pump 17 gpm & 6 & 399 & 19 & - & - & - & - \\
\hline USGS 20 & Pump 18 gpm & 6 & 658 & 10 & & - & - & - \\
\hline USGS 23 & Pump 25 gpm & $\begin{array}{l}6<430 \\
5>430\end{array}$ & 457 & - & 19 & - & - & - \\
\hline USGS $27^{1}$ & Pump $20 \mathrm{gpm}^{4}$ & 6 & 312 & 19 & - & - & - & - \\
\hline USGS 31 & Pump 36 gpm & $\begin{aligned} 8 & <306 \\
10 & >306\end{aligned}$ & 428 & 5 & - & - & - & - \\
\hline USGS 32 & Pump 36 gpm & $\begin{array}{l}6<324 \\
5.5>324\end{array}$ & 392 & 5 & - & - & - & - \\
\hline USGS 34 & Pump 30 gpm & 10 & 700 & 18 & - & - & - & - \\
\hline USGS 37 & Pump 25 gpm & 6 & 572 & - & 15 & - & - & - \\
\hline USGS 38 & Pump 4 gpm4 & 4 & 724 & 18 & - & - & - & - \\
\hline USGS 42 & Pump 25 gpm & 6 & 678 & 10 & - & - & - & - \\
\hline USGS 43 & Pump 6 gpm & 6 & 564 & - & 15 & - & - & - \\
\hline USGS 44 & Pump 25 gpm & 6 & 650 & 12 & - & - & - & - \\
\hline USGS 46 & Pump 25 gpm & 6 & 651 & 12 & - & - & - & - \\
\hline USGS 47 & Pump 8 gpm & 6 & 651 & - & 15 & - & - & - \\
\hline USGS 48 & Pump 29 gpm & 6 & 750 & 10 & - & - & - & - \\
\hline USGS 51 & Pump 4 gpm & 6 & 647 & 10 & - & - & - & - \\
\hline USGS 52 & Pump 30 gpm & 6 & 602 & - & 10 & - & - & - \\
\hline USGS 53 & Bail & 6 & 72 & - & 13 & - & - & - \\
\hline USGS 54 & Pump 4 gpm & 6 & 81 & - & 13 & - & - & - \\
\hline USGS $55^{1}$ & Pump 1 gpm & 6 & 81 & 13 & - & - & - & - \\
\hline USGS 56 & Bail & 6 & 79 & - & 13 & - & - & - \\
\hline USGS 57 & Pump 30 gpm & 6 & 582 & - & 12 & - & - & - \\
\hline
\end{tabular}




\begin{tabular}{|c|c|c|c|c|c|c|c|c|}
\hline \multirow{2}{*}{$\begin{array}{c}\text { Local } \\
\text { site } \\
\text { identifier }\end{array}$} & \multirow{2}{*}{$\begin{array}{c}\text { Method } \\
\text { of } \\
\text { sampling }\end{array}$} & \multirow{2}{*}{$\begin{array}{c}\text { Hole } \\
\text { diameter } \\
\text { (inches) }\end{array}$} & \multirow{2}{*}{$\begin{array}{l}\text { Well } \\
\text { depth } \\
\text { (feet) }\end{array}$} & \multicolumn{2}{|c|}{$\begin{array}{l}\text { Analysis type } \\
\text { (see code) }\end{array}$} & \multirow{2}{*}{$\begin{array}{c}\text { Westbay } \\
\text { Code; zone }\end{array}$} & \multicolumn{2}{|c|}{$\begin{array}{c}\text { NRF } \\
\text { (see code) }\end{array}$} \\
\hline & & & & April & October & & May & November \\
\hline USGS 58 & Pump 26 gpm & 6 & 503 & 13 & - & - & - & - \\
\hline USGS 59 & Pump 15 gpm & 6 & 587 & 10 & - & - & - & - \\
\hline USGS 60 & Pump 6 gpm & 6 & 117 & - & 13 & - & - & - \\
\hline USGS 61 & Pump 6 gpm & 4 & 123 & 13 & - & - & - & - \\
\hline USGS 62 & Pump 5 gpm & 8 & 165 & 13 & - & - & - & - \\
\hline USGS 63 & Pump 5 gpm & 10 & 109 & - & 13 & - & - & - \\
\hline USGS $65^{1}$ & Pump 8 gpm & 4 & 498 & 28 & - & - & - & - \\
\hline USGS $66^{1}$ & Bail & 4 & 201 & - & 13 & - & - & - \\
\hline USGS 67 & Pump 8 gpm & $\begin{array}{l}6<465 \\
4>465\end{array}$ & 694 & - & 10 & - & - & - \\
\hline USGS $68^{1}$ & Pump $1 \mathrm{gpm}^{4}$ & 10 & 128 & 30 & - & - & - & - \\
\hline USGS 69 & Pump 5 gpm & 4 & 115 & - & 9 & - & - & - \\
\hline USGS $70^{1}$ & Pump 6 gpm & 8 & 100 & 13 & - & - & - & - \\
\hline USGS 71 & Bail & 5 & 171 & - & 13 & - & - & - \\
\hline USGS 72 & Bail & 4 & 174 & 30 & - & - & - & - \\
\hline USGS $73^{1}$ & Bail & 6 & 127 & - & 13 & - & - & - \\
\hline USGS 76 & Pump 29 gpm & 6 & 718 & 14 & - & - & - & - \\
\hline USGS 77 & Pump 25 gpm & 6 & 586 & - & 21 & - & - & - \\
\hline USGS 79 & Pump 30 gpm & 6 & 702 & 7 & - & - & - & - \\
\hline USGS 82 & Pump 25 gpm & 6 & 693 & 10 & - & - & - & - \\
\hline USGS 84 & Pump 5 gpm & 6 & 505 & - & 25 & - & - & - \\
\hline USGS $85^{1}$ & Pump 23 gpm & 6 & 614 & 10 & - & - & - & - \\
\hline USGS 86 & Pump 19 gpm & 8 & 691 & - & 19 & - & - & - \\
\hline USGS $87^{1}$ & Pump 2 gpm & 4 & 673 & 23 & - & - & - & - \\
\hline USGS 88 & Pump 2 gpm & 4 & 663 & - & 23 & - & - & - \\
\hline USGS 89 & Pump 5 gpm & 6 & 637 & 17 & - & - & - & - \\
\hline USGS 92 & Bail & 3.5 & 214 & 16 & - & - & - & - \\
\hline USGS 97 & Pump 27 gpm & 4 & 510 & 25 & - & - & - & - \\
\hline USGS 98 & Pump 25 gpm & 4 & 508 & - & 25 & - & - & - \\
\hline USGS 99 & Pump 25 gpm & 4 & 440 & - & 8 & - & - & - \\
\hline USGS $100^{1}$ & Pump $10 \mathrm{gpm}^{4}$ & 6 & 750 & 8 & - & - & - & - \\
\hline USGS 101 & Pump 13 gpm & $\begin{array}{l}6<750 \\
4>750\end{array}$ & 842 & - & 19 & - & - & - \\
\hline USGS 102 & Pump 29 gpm & 6 & 444 & 5 & - & - & 33 & 35 \\
\hline USGS $103^{1,5}$ & Multi-depth thief sampler & $(6)$ & 1,297 & - & - & $\begin{array}{l}\text { 19; zones } \\
1,3,6,9\end{array}$ & - & - \\
\hline USGS $104^{1,3}$ & Pump 26 gpm & 8 & 700 & - & 6 & & - & - \\
\hline USGS $105^{1}$ & Multi-depth thief sampler & $(6)$ & 1,300 & - & - & $\begin{array}{l}19 \text {; zones } \\
5,8,11\end{array}$ & - & - \\
\hline USGS 106 & Pump 24 gpm & 8 & 760 & - & 6 & - & - & - \\
\hline USGS 107 & Pump 30 gpm & 8 & 690 & 26 & - & - & - & - \\
\hline USGS $108^{1,5}$ & Multi-depth thief sampler & (6) & 1,196 & - & - & 19 ; zones 1,9 & - & - \\
\hline USGS 110A & Pump 24 gpm & 6 & 644 & - & 19 & - & - & - \\
\hline USGS 111 & Pump $15 \mathrm{gpm}^{4}$ & 8 & 560 & 10 & & - & - & - \\
\hline USGS $112^{1,3}$ & Pump 30 gpm & 8 & 507 & - & 10 & - & - & - \\
\hline USGS 113 & Pump 25 gpm & 6 & 556 & 12 & & - & - & - \\
\hline USGS $114^{3}$ & Pump $10 \mathrm{gpm}^{4}$ & 6 & 560 & - & 10 & - & - & - \\
\hline USGS $115^{1}$ & Pump 5 gpm & 6 & 581 & - & 10 & - & - & - \\
\hline USGS 116 & Pump 20 gpm & 6 & 572 & 10 & & - & - & - \\
\hline USGS $117^{3}$ & Pump $12 \mathrm{gpm}^{4}$ & 6.5 & 655 & & 17 & - & - & - \\
\hline USGS $119^{3}$ & Pump 2 gpm $^{4}$ & 6.5 & 705 & 17 & & - & - & - \\
\hline USGS $120^{1,3}$ & Pump 27 gpm & 6.5 & 705 & - & 23 & - & - & - \\
\hline USGS 123 & Pump 3 gpm & 6 & 514 & - & 10 & - & - & - \\
\hline
\end{tabular}




\begin{tabular}{|c|c|c|c|c|c|c|c|c|}
\hline \multirow{2}{*}{$\begin{array}{c}\text { Local } \\
\text { site } \\
\text { identifier }\end{array}$} & \multirow{2}{*}{$\begin{array}{l}\text { Method } \\
\text { of } \\
\text { sampling }\end{array}$} & \multirow{2}{*}{$\begin{array}{c}\text { Hole } \\
\text { diameter } \\
\text { (inches) }\end{array}$} & \multirow{2}{*}{$\begin{array}{l}\text { Well } \\
\text { depth } \\
\text { (feet) }\end{array}$} & \multicolumn{2}{|c|}{$\begin{array}{c}\text { Analysis type } \\
\text { (see code) }\end{array}$} & \multirow{2}{*}{$\begin{array}{c}\text { Westbay } \\
\text { Code; zone }\end{array}$} & \multicolumn{2}{|c|}{$\begin{array}{c}\text { NRF } \\
\text { (see code) }\end{array}$} \\
\hline & & & & April & October & & May & November \\
\hline USGS $124^{1,3}$ & Pump 15 gpm & 4 & 800 & 6 & - & - & - & - \\
\hline USGS 127 & Pump 25 gpm & 6 & 596 & 20 & - & - & - & - \\
\hline USGS 128 & Pump 23 gpm & 4.5 & 615 & - & 18 & - & - & - \\
\hline USGS 130 & Pump $25 \mathrm{gpm}$ & 4.5 & 636 & - & 19 & - & - & - \\
\hline USGS $131 \mathrm{~A}^{5}$ & Multi-depth thief sampler & (6) & 1,198 & - & - & 19 ; zones 8,12 & - & - \\
\hline USGS $132^{1,5}$ & Multi-depth thief sampler & (6) & 1,238 & - & - & 19 ; zone 14 & - & - \\
\hline USGS $133^{5}$ & Multi-depth thief sampler & (6) & 798 & - & - & 19 ; zone 10 & - & - \\
\hline USGS 136 & Pump 21 gpm & 6 & 560 & - & 14 & - & - & - \\
\hline USGS $137 \mathrm{~A}^{1}$ & Multi-depth thief sampler & (6) & 1,317 & - & - & 19 ; zones 4,5 & - & - \\
\hline USGS 140 & Pump 24 gpm & 6 & 546 & - & 14 & - & - & - \\
\hline USGS 143 & Pump 18 gpm & 6 & 801 & 19 & - & - & - & - \\
\hline USGS 144 & Pump 18 gpm & 6 & 627 & 19 & - & - & - & - \\
\hline USGS 146 & Pump 20 gpm & 6 & 800 & - & 19 & - & - & - \\
\hline USGS 147 & Pump 13 gpm & 8 & 729 & 19 & - & - & - & - \\
\hline USGS $148 \mathrm{~A}^{1}$ & Pump 16 gpm & 4 & 759 & - & 19 & - & - & - \\
\hline USGS $149^{5}$ & Multi-depth thief sampler & (6) & 970 & - & - & 19; all 4 zones & - & - \\
\hline
\end{tabular}

${ }^{1}$ Well is sampled with someone from the State of Idaho's Idaho National Laboratory Oversight Program

${ }^{2}$ Well is sampled monthly for organics (sample code 27) - SH1380

${ }^{3}$ Well is sampled with someone from Shoshone/Bannock Tribe

${ }^{4}$ Indicates well needs to be cut back to pump rate indicated; all other pump rates are approximate.

${ }^{5}$ Site sample schedules for the multi-depth sampler are subject to change from year to year; code 29 after installation; routinely will sample for code 19 at select zones.

${ }^{6} \mathrm{Hole}$ diameter is not required for bore hole volume calculations with Multi-depth thief samplers.

\section{Codes for Types of Analyses (Number of Bottles Needed in Parenthesis)}

1. ${ }^{3} \mathrm{H}, \mathrm{Cl}^{-}(2)$

2. ${ }^{3} \mathrm{H}, \alpha, \beta, \mathrm{Cl}^{-}, \mathrm{Na}^{+}, \mathrm{NO}^{3-}(5)$

3. ${ }^{3} \mathrm{H}, \mathrm{Cl}^{-}, \alpha, \beta,(3)$

4. ${ }^{3} \mathrm{H},{ }^{90} \mathrm{Sr}, \mathrm{Cl}^{-}, \mathrm{Cr}, \mathrm{SO}^{4--}(4)$

5. ${ }^{3} \mathrm{H}, \mathrm{Cl}^{-}, \mathrm{Na}^{+}, \mathrm{NO}^{3-}, \mathrm{SO}^{4--}(4)$

6. ${ }^{3} \mathrm{H}, \mathrm{Cl}^{-}, \mathrm{Na}^{+}, \mathrm{NO}^{3-}(4)$

7. ${ }^{3} \mathrm{H}, \mathrm{Cl}^{-}, \mathrm{Cr}, \mathrm{Na}^{+}, \mathrm{SO}^{4--}(3)$

8. ${ }^{3} \mathrm{H}, \mathrm{Cl}^{-}, \mathrm{Cr}, \mathrm{Na}^{+}, \mathrm{NO}^{3-}, \mathrm{SO}^{4--}(4)$

9. ${ }^{3} \mathrm{H},{ }^{90} \mathrm{Sr}, \mathrm{Y}_{\mathrm{Spec}}, \mathrm{Cl}^{-}, \mathrm{Na}^{+}, \mathrm{SO}^{4--}(4)$

10. ${ }^{3} \mathrm{H},{ }^{90} \mathrm{Sr}, \mathrm{Cl}^{-}, \mathrm{Na}^{+}, \mathrm{NO}^{3-}, \mathrm{SO}^{4--}(5)$

11. ${ }^{3} \mathrm{H}, \alpha, \beta, \Upsilon \mathrm{Spec}, \mathrm{Cl}^{-}, \mathrm{Na}^{+}(5)$

12. ${ }^{3} \mathrm{H},{ }^{90} \mathrm{Sr}, \Upsilon \mathrm{Spec}, \mathrm{Cl}^{-}, \mathrm{Na}^{+}, \mathrm{NO}^{3-}, \mathrm{SO}^{4--}(5)$

13. ${ }^{3} \mathrm{H},{ }^{90} \mathrm{Sr}, \Upsilon \mathrm{Spec}, \mathrm{Cl}^{-}, \mathrm{Cr}, \mathrm{Na}^{+}, \mathrm{SO}^{4--}(4)$

14. ${ }^{3} \mathrm{H},{ }^{90} \mathrm{Sr}, \mathrm{Y} \mathrm{Spec}, \mathrm{Cl}^{-}, \mathrm{Cr}, \mathrm{Na}^{+}, \mathrm{NO}^{3-}, \mathrm{SO}^{4--}(5)$

15. ${ }^{3} \mathrm{H},{ }^{90} \mathrm{Sr}, \mathrm{r}$ Spec, ${ }^{241} \mathrm{Am},{ }^{238} \mathrm{Pu},{ }^{239,240} \mathrm{Pu}, \mathrm{Cl}^{-}, \mathrm{Na}^{+}, \mathrm{NO}^{3-}, \mathrm{SO}^{4--}(5)$

16. ${ }^{3} \mathrm{H},{ }^{90} \mathrm{Sr}$, Ү Spec, ${ }^{241} \mathrm{Am},{ }^{238} \mathrm{Pu},{ }^{239,240} \mathrm{Pu}, \mathrm{Cl}^{-}, \mathrm{VOC}$ 's (6)

17. ${ }^{3} \mathrm{H}, \mathrm{Cl}^{-}, \mathrm{Cr}, \mathrm{Na}^{+}, \mathrm{NO}^{3-}, \mathrm{VOCs}, \mathrm{SO}^{4--}(7)$

18. ${ }^{3} \mathrm{H}, \alpha, \beta, \mathrm{Cl}^{-}, \mathrm{Na}^{+}, \mathrm{Cr}, \mathrm{NO}^{3-}, \mathrm{SO}^{4--}, \mathrm{F}^{-}, \mathrm{VOCs},(8)$

19. ${ }^{3} \mathrm{H}, \alpha, \beta, \mathrm{Cl}^{-}, \mathrm{Na}^{+}, \mathrm{Cr}, \mathrm{SO}^{4--}, \mathrm{NO}^{3-}(5)$

20. ${ }^{3} \mathrm{H},{ }^{90} \mathrm{Sr}, \alpha, \beta, \Upsilon$ Spec, $\mathrm{Cl}^{-}, \mathrm{Na}^{+}, \mathrm{Cr}, \mathrm{NO}^{3-},(6)$

21. ${ }^{3} \mathrm{H},{ }^{90} \mathrm{Sr}, \alpha, \beta$, Ү Spec, ${ }^{241} \mathrm{Am},{ }^{238} \mathrm{Pu},{ }^{239,240} \mathrm{Pu}, \mathrm{Cl}^{-}, \mathrm{Na}^{+}, \mathrm{Cr}, \mathrm{NO}^{3-}, \mathrm{F}^{-}, \mathrm{SO}^{4--} \mathrm{VOCs},(9)$ 
22. ${ }^{3} \mathrm{H}, \alpha, \beta, \mathrm{Cl}^{-}, \mathrm{Na}^{+}, \mathrm{Cr}, \mathrm{NO}^{3}-, \mathrm{SO}^{4--}, \mathrm{VOC}$ 's, (8)

23. ${ }^{3} \mathrm{H},{ }^{90} \mathrm{Sr}, \alpha, \beta$, Ү Spec, ${ }^{241} \mathrm{Am},{ }^{238} \mathrm{Pu},{ }^{239,240} \mathrm{Pu}, \mathrm{Cl}^{-}, \mathrm{Na}^{+}, \mathrm{Cr}, \mathrm{NO}^{3-}, \mathrm{SO}^{4--} \mathrm{VOCs},(9)$

24. ${ }^{3} \mathrm{H},{ }^{90} \mathrm{Sr}, \alpha, \beta, \Upsilon$ Spec, $\mathrm{Cl}^{-}, \mathrm{Na}^{+}, \mathrm{NO}^{3-}$, VOCs, $\mathrm{Hg}$, metals ( $\left.\mathrm{SH} 1050\right)+\mathrm{As}, \mathrm{Tl}(12)$

25. ${ }^{3} \mathrm{H}, \alpha, \beta, \mathrm{Cl}^{-}, \mathrm{Na}^{+}, \mathrm{NO}^{3-}, \mathrm{SO}^{4--}, \mathrm{VOCs}, \mathrm{Hg}$, metals $(\mathrm{SH} \mathrm{1050)}+\mathrm{As}, \mathrm{Se}(10)$

26. ${ }^{3} \mathrm{H}, \alpha, \beta, \mathrm{Cl}^{-}, \mathrm{Na}^{+}, \mathrm{Cr}, \mathrm{NO}^{3-},(5)$

27. $\operatorname{VOCs}(3)$

28. ${ }^{3} \mathrm{H},{ }^{90} \mathrm{Sr}, \alpha, \beta, \Upsilon \mathrm{Spec},{ }^{241} \mathrm{Am},{ }^{238} \mathrm{Pu},{ }^{239,240} \mathrm{Pu}, \mathrm{Cl}^{-}, \mathrm{Na}^{+}, \mathrm{NO}^{3-}, \mathrm{SO}^{4--}$, VOCs, $\mathrm{Hg}$, metals (SH 1050) + As, Se (12)

29. New well: Alkalinity, ${ }^{3} \mathrm{H},{ }^{90} \mathrm{Sr}, \alpha, \beta$, Ү Spec, ${ }^{241} \mathrm{Am},{ }^{238} \mathrm{Pu},{ }^{239,240} \mathrm{Pu}, \mathrm{NO}^{3-}$, VOCs, $\mathrm{Hg}$, anions ( $\mathrm{SH} 670)$, metals and cations ( $\mathrm{SH} 2126)+\mathrm{B}$, U-isotopes, $\mathrm{H}^{2} / \mathrm{O}^{18}$ (13)

30. ${ }^{3} \mathrm{H},{ }^{90} \mathrm{Sr}, \alpha, \beta$, Ү Spec, $\mathrm{Cl}^{-}, \mathrm{Na}^{+}, \mathrm{SO}^{4--}$, metals ( $\left.\mathrm{SH} 1281\right)(7)$

31. $\mathrm{NRF}{ }^{3} \mathrm{H},{ }^{90} \mathrm{Sr},{ }^{63} \mathrm{Ni}, \Upsilon \mathrm{Spec}$, raw metals, raw and filtered nutrients, anions, VOCs, Semivols, $\mathrm{pH} / \mathrm{TDS},(14)$

32. $\mathrm{NRF}^{3} \mathrm{H},{ }^{90} \mathrm{Sr},{ }^{63} \mathrm{Ni}, \Upsilon \mathrm{Spec}$, raw and filtered metals, raw and filtered nutrients, anions, VOCs, Semi-vols, $\mathrm{pH} / \mathrm{TDS},(15)$

33. $\mathrm{NRF}{ }^{3} \mathrm{H},{ }^{90} \mathrm{Sr},{ }^{63} \mathrm{Ni}, \mathrm{r}$ Spec, raw metals, raw and filtered nutrients, anions, $\mathrm{pH} / \mathrm{TDS}$, (9)

34. $\mathrm{NRF}{ }^{3} \mathrm{H},{ }^{90} \mathrm{Sr},{ }^{63} \mathrm{Ni}, \Upsilon \mathrm{Spec}$, raw and filtered metals, raw and filtered nutrients, anions, $\mathrm{pH} / \mathrm{TDS},(10)$

Table 1.2. Constituent and type of sample.

[Abbreviations: $\mathrm{mL}$, milliliter]

\begin{tabular}{|c|c|c|c|}
\hline Type of analyses & Lab & $\begin{array}{l}\text { Size of sample and } \\
\text { schedule or lab code }\end{array}$ & Type of sample treatment \\
\hline${ }^{3} \mathrm{H}(\mathrm{Ru})$ & RESL & $500 \mathrm{~mL}$ (Apr, Oct) & Raw water, unacidified, rinse bottle \\
\hline${ }^{90} \mathrm{Sr}(\mathrm{RA})$ & RESL & $500 \mathrm{~mL}$ & Raw water, preserved with $2 \mathrm{~mL} \mathrm{HNO}_{3}$, no rinse \\
\hline${ }^{90} \mathrm{Sr}, \gamma \mathrm{Spec}(\mathrm{RA})$ & RESL & $500 \mathrm{~mL}$ & Raw water, preserved with $2 \mathrm{~mL} \mathrm{HNO}_{3}$, no rinse \\
\hline$\alpha, \beta$ (RA) & RESL & $500 \mathrm{~mL}$ & Raw water, preserved with $2 \mathrm{~mL} \mathrm{HNO}_{3}$, no rinse \\
\hline $\begin{array}{l}{ }^{241} \mathrm{Am},{ }^{238} \mathrm{Pu},{ }^{239,240} \mathrm{Pu} \\
\text { (RA) }\end{array}$ & RESL & $500 \mathrm{~mL}$ & Raw water, preserved with $2 \mathrm{~mL} \mathrm{HNO}_{3}$, no rinse \\
\hline $\begin{array}{l}{ }^{90} \mathrm{Sr}, \gamma \mathrm{Spec},{ }^{241} \mathrm{Am},{ }^{238} \mathrm{Pu}, \\
{ }^{239,240} \mathrm{Pu}(\mathrm{RA})\end{array}$ & RESL & $1 \mathrm{~L}$ & Raw water, preserved with $4 \mathrm{~mL} \mathrm{HNO}_{3}$, no rinse \\
\hline$\gamma \operatorname{Spec}(\mathrm{RA})$ & RESL & $500 \mathrm{~mL}$ & Raw water, preserved with $2 \mathrm{~mL} \mathrm{HNO}_{3}$, no rinse \\
\hline $\mathrm{F}^{-* *}(\mathrm{FU})$ & NWQL & $250 \mathrm{~mL} ; \mathrm{LC} 651$ & Filtered, unacidified, rinse poly bottle \\
\hline $\mathrm{Na}^{+*}(\mathrm{FA})$ & NWQL & $250 \mathrm{~mL} ; \mathrm{LC} 675$ & $\begin{array}{l}\text { Filtered, preserved with } 2 \mathrm{~mL} \text { Ultrex } \mathrm{HNO}_{3} \text {, rinse } \\
\text { poly bottle }\end{array}$ \\
\hline $\mathrm{Cr} *(\mathrm{FA})$ & NWQL & $250 \mathrm{~mL} ; \mathrm{LC} 722$ & $\begin{array}{l}\text { Filtered, preserved with } 2 \mathrm{~mL} \text { Ultrex } \mathrm{HNO}_{3} \text {, rinse } \\
\text { poly bottle }\end{array}$ \\
\hline $\mathrm{Cl}^{-* *}(\mathrm{FU})$ & NWQL & $250 \mathrm{~mL} ; \mathrm{LC} 1571$ & Filtered, unacidified, rinse poly bottle \\
\hline $\mathrm{SO}^{4--* *}(\mathrm{FU})$ & NWQL & $250 \mathrm{~mL} ; \mathrm{LC} 1572$ & Filtered, unacidified, rinse poly bottle \\
\hline $\mathrm{Hg}(\mathrm{FAM})$ & NWQL & $250 \mathrm{~mL} ; \mathrm{LC} 2707$ & $\begin{array}{l}\text { Filtered, preserved with } 2 \mathrm{~mL} 6 \mathrm{~N} \mathrm{HCL} \text {, rinse, clear } \\
\text { glass bottle }\end{array}$ \\
\hline $\begin{array}{l}\text { Carbon-13/carbon-12 } \\
\text { (FUS) }\end{array}$ & RSIL & 1L, LC 1851 & $\begin{array}{l}\text { Filtered, unacidified, plastic coated glass bottle } \\
\text { fitted with polyseal cone cap, chill, provide } \\
\text { alkalinity \& pH }\end{array}$ \\
\hline $\mathrm{NO}^{3-}(\mathrm{FCC})$ & NWQL & $125 \mathrm{~mL} ; \mathrm{SH} 101$ & Filtered, chilled, brown poly bottle, rinse bottle \\
\hline SH 670 anions (FU) & NWQL & $250 \mathrm{~mL} ; \mathrm{SH} 670$ & Filtered, unacidified, rinse poly bottle \\
\hline Sp. Cond. (RU) & & $250 \mathrm{~mL} ; \mathrm{SH} 670$ & Raw water, unacidified, rinse poly bottle \\
\hline SH 1050 metals (FA) & NWQL & $250 \mathrm{~mL}$; SH 1050 and & Filtered, preserved with $2 \mathrm{~mL}$ ultrex $\mathrm{HNO}_{3}$, rinse \\
\hline As, $\mathrm{Tl}(\mathrm{FA})$ & & LC 3122 and 2508 & \\
\hline Sp. Cond. (RU) & & $250 \mathrm{~mL}$; SH 1050 & Raw water, unacidified, rinse poly bottle \\
\hline
\end{tabular}




\begin{tabular}{|c|c|c|c|}
\hline Type of analyses & Lab & $\begin{array}{l}\text { Size of sample and } \\
\text { schedule or lab code }\end{array}$ & Type of sample treatment \\
\hline $\begin{array}{l}\text { SH } 1050 \text { metals (FA) } \\
\text { As. Se (FA) }\end{array}$ & NWQL & $\begin{array}{l}250 \mathrm{~mL} ; \mathrm{SH} 1050 \text { and } \\
\mathrm{LC} 3122 \text { and } 3132\end{array}$ & $\begin{array}{l}\text { Filtered, preserved with } 2 \mathrm{~mL} \text { Ultrex } \mathrm{HNO}_{3} \text {, rinse } \\
\text { poly bottle }\end{array}$ \\
\hline Sp. Cond. (RU) & & $250 \mathrm{~mL}$; SH 1050 & Raw water, unacidified, rinse, poly bottle \\
\hline $\begin{array}{l}\text { Uranium 234, 235, } 238 \\
\text { isotopes (FAR) }\end{array}$ & $\begin{array}{l}\text { Test } \\
\text { America }\end{array}$ & 1L; SH 1130 & $\begin{array}{l}\text { Filtered, acidified with } 4 \mathrm{~mL} \text { Ultrex } \mathrm{HNO}_{3} \text {, rinse } \\
\text { poly bottle }\end{array}$ \\
\hline $\begin{array}{l}\text { Oxygen/deuterium } \\
\text { isotopes (RUS) }\end{array}$ & RSIL & $60 \mathrm{~mL}$; SH 1142 & Raw water, unacidified, no rinse \\
\hline VOCs (GCV) & NWQL & (3) $40 \mathrm{~mL}$; SH1380 & $\begin{array}{l}\text { Raw water, chilled, unacidified, rinse glass bottle, } \\
\text { amber }\end{array}$ \\
\hline $\begin{array}{l}\text { SH } 1281 \text { TCLP metals } \\
\text { (RA) }\end{array}$ & NWQL & $\begin{array}{l}250 \mathrm{~mL} ; \mathrm{SH} 1281 \\
250 \mathrm{~mL} ; \mathrm{SH} 1281\end{array}$ & $\begin{array}{l}\text { Raw, preserved with } 2 \mathrm{~mL} \text { Ultrex } \mathrm{HNO}_{3} \text {, rinse poly } \\
\text { bottle }\end{array}$ \\
\hline $\mathrm{Hg}$ (RAM) & & & $\begin{array}{l}\text { Raw water, preserved with } 2 \mathrm{ml} 6 \mathrm{~N} \mathrm{HCl} \text {, rinse clear } \\
\text { glass bottle }\end{array}$ \\
\hline $\begin{array}{l}\text { SH } 2126 \text { metals \& cations } \\
\text { (FA) }\end{array}$ & NWQL & $\begin{array}{l}250 \mathrm{~mL} ; \mathrm{SH} 2126 \\
\text { and LC } 2110\end{array}$ & $\begin{array}{l}\text { Filtered, preserved with } 2 \mathrm{ml} \text { Ultrex } \mathrm{HNO}_{3} \text {, rinse } \\
\text { poly bottle }\end{array}$ \\
\hline $\mathrm{B}(\mathrm{FA})$ & & $250 \mathrm{~mL} ; \mathrm{SH} 2126$ & Raw water, unacidified, rinse poly bottle \\
\hline $\begin{array}{l}\text { Sp. Cond. and } \mathrm{pH}(\mathrm{RU}) \\
{ }^{129} \mathrm{I}\end{array}$ & PRIME & $1 \mathrm{~L}$ & $\begin{array}{l}\text { Filtered, unacidified, rinse, polyseal cap, no head } \\
\text { space, amber glass or poly }\end{array}$ \\
\hline
\end{tabular}

*Analysis can be requested from the same bottle.

**Analysis can be requested from the same bottle. 


\section{Appendix 2. Water-Level Measurement Schedule.}

Table 2.1. Water-level measurement schedule.

[Abbreviations: Jan, January; Feb, February; Mar, March; Apr, April; Jun, June; Jul, July; Aug, August; Sep, September; Oct, October; A, aquifer; AM, aquifer measured monthly; AA, aquifer well measured annually; ANRF, aquifer well measured for NRF; AS, aquifer well measured semi-annually; AQ, aquifer well measured quarterly; PA, perched well measured annually; PM, perched well measured monthly; PS, perched well measured semi-annually; PQ, perched well measured quarterly; R, well equipped with continuous water-level recorder; RT, continuous recorded real-time; S, water sample and water level collected]

\begin{tabular}{|c|c|c|c|c|c|c|c|c|c|c|c|c|c|}
\hline WELL NAME & Type & Jan & Feb & Mar & Apr & May & Jun & Jul & Aug & Sep & Oct & Nov & Dec \\
\hline USGS 1 & A & & RT & & & RT & & & RT & & $\mathrm{S}$ & RT & \\
\hline USGS 2 & $\mathrm{~A}$ & $\mathrm{AQ}$ & & & $\mathrm{S}$ & & & $\mathrm{AQ}$ & & & $\mathrm{AQ}$ & & \\
\hline USGS 4 & $\mathrm{~A}$ & & $\mathrm{R}$ & & & $\mathrm{R}$ & & & $\mathrm{R}$ & & & $\overline{\mathrm{R}}$ & \\
\hline USGS 5 & A & AQ & & & $\mathrm{S}$ & & & $\mathrm{AQ}$ & & & $\mathrm{AQ}$ & & \\
\hline USGS 6 & $\mathrm{~A}$ & $\mathrm{AQ}$ & & $\overline{\mathrm{AQ}}$ & & & & $\mathrm{AQ}$ & & & $\mathrm{AQ}$ & & \\
\hline USGS 7 & $\mathrm{~A}$ & $\mathrm{AQ}$ & & & $\mathrm{S}$ & & & $\mathrm{AQ}$ & & & $\mathrm{AQ}$ & & \\
\hline USGS 8 & A & $\mathrm{AQ}$ & & & $\mathrm{S}$ & & & $\mathrm{AQ}$ & & & $\mathrm{AQ}$ & & \\
\hline USGS 9 & $\mathrm{~A}$ & & $\mathrm{R}$ & & & $\mathrm{R}$ & & & $\mathrm{R}$ & & $\mathrm{S}$ & $\mathrm{R}$ & \\
\hline USGS 11 & A & $\mathrm{AQ}$ & & & $\mathrm{S}$ & & & $\mathrm{AQ}$ & & & $\mathrm{AQ}$ & & \\
\hline USGS 12 & A & & $\mathrm{R}$ & & $\mathrm{S}$ & $R \& S$ & & & $\mathrm{R}$ & & & $\mathrm{S}$ & \\
\hline USGS 13 & A & & & & AA & & & & & & & & \\
\hline USGS 14 & A & AQ & & & $\mathrm{AQ}$ & & & $\mathrm{AQ}$ & & & $\mathrm{S}$ & & \\
\hline USGS 15 & A & $\mathrm{AQ}$ & & & $\mathrm{AQ}$ & & & $\mathrm{AQ}$ & & & $\mathrm{AQ}$ & & \\
\hline USGS 17 & A & $\mathrm{AQ}$ & & & $\mathrm{S}$ & & & $\mathrm{AQ}$ & & & $\mathrm{AQ}$ & & \\
\hline USGS 18 & $\mathrm{~A}$ & $\mathrm{AQ}$ & & & $\mathrm{S}$ & & & $\mathrm{AQ}$ & & & $\mathrm{AQ}$ & & \\
\hline USGS 19 & A & AM & AM & AM & $\mathrm{S}$ & AM & AM & $\mathrm{AM}$ & AM & AM & $\mathrm{AM}$ & AM & AM \\
\hline USGS 20 & $\mathrm{~A}$ & $\mathrm{AQ}$ & & & $\mathrm{S}$ & & & $\overline{\mathrm{AQ}}$ & & & $\overline{\mathrm{AQ}}$ & & \\
\hline USGS 21 & $\mathrm{~A}$ & & RT & & & RT & & & RT & & & RT & \\
\hline USGS 22 & A & $\mathrm{AQ}$ & & & $\mathrm{AQ}$ & & & $\mathrm{AQ}$ & & & $\mathrm{AQ}$ & & \\
\hline USGS 23 & $\mathrm{~A}$ & $\mathrm{AQ}$ & & & $\mathrm{AQ}$ & & & $\mathrm{AQ}$ & & & $\mathrm{S}$ & & \\
\hline USGS 24 & A & & $\mathrm{R}$ & & & $\mathrm{R}$ & & & $\mathrm{R}$ & & & $\mathrm{R}$ & \\
\hline USGS 25 & A & & $\mathrm{R}$ & & & $\mathrm{R}$ & & & $\mathrm{R}$ & & & $\mathrm{R}$ & \\
\hline USGS 26 & A & $\mathrm{AQ}$ & & & $\mathrm{AQ}$ & & & $\mathrm{AQ}$ & & & $\mathrm{AQ}$ & & \\
\hline USGS 27 & $\mathrm{~A}$ & AM & AM & $\mathrm{AM}$ & $\mathrm{S}$ & AM & $\mathrm{AM}$ & $\mathrm{AM}$ & AM & AM & $\mathrm{AM}$ & AM & AM \\
\hline USGS 28 & A & & & AS & & & & & & AS & & & \\
\hline USGS 29 & A & & & AS & & & & & & & AS & & \\
\hline USGS 30A & A & & & $\mathrm{AQ}$ & & & $\mathrm{AQ}$ & & & $\mathrm{AQ}$ & & & $\mathrm{AQ}$ \\
\hline USGS 30C & A & & & $\mathrm{AQ}$ & & & $\mathrm{AQ}$ & & & $\mathrm{AQ}$ & & & $\mathrm{AQ}$ \\
\hline
\end{tabular}




\begin{tabular}{|c|c|c|c|c|c|c|c|c|c|c|c|c|c|}
\hline WELL NAME & Type & Jan & Feb & Mar & Apr & May & Jun & Jul & Aug & Sep & Oct & Nov & Dec \\
\hline USGS 31 & A & & & & $\mathrm{S}$ & & & & & & $\mathrm{AS}$ & & \\
\hline USGS 32 & $\mathrm{~A}$ & & & & $\mathrm{~S}$ & & & & & & $\mathrm{AS}$ & & \\
\hline USGS 34 & A & & & & $\mathrm{S}$ & & & & & & & & \\
\hline USGS 37 & $\mathrm{~A}$ & & & & & & & & & & $\mathrm{~S}$ & & \\
\hline USGS 38 & $\mathrm{~A}$ & & & & $\mathrm{~S}$ & & & & & & & & \\
\hline USGS 39 & $\mathrm{~A}$ & $\mathrm{AQ}$ & & $\mathrm{AQ}$ & & & & $\mathrm{AQ}$ & & & $\mathrm{AQ}$ & & \\
\hline USGS 42 & $\mathrm{~A}$ & & & & $\mathrm{~S}$ & & & & & & & & \\
\hline USGS 43 & A & & & & & & & & & & $\mathrm{S}$ & & \\
\hline USGS 44 & $\mathrm{~A}$ & & & & $\mathrm{~S}$ & & & & & & & & \\
\hline USGS 46 & A & & & & $\mathrm{S}$ & & & & & & & & \\
\hline USGS 47 No wl sample only & $\mathrm{A}$ & & & & & & & & & & $\mathrm{S}$ & & \\
\hline USGS 48 & A & & & & $\mathrm{S}$ & & & & & & $\mathrm{AS}$ & & \\
\hline USGS 51 & A & & & & $\mathrm{S}$ & & & & & & & & \\
\hline USGS 52 & $\mathrm{~A}$ & & & & & & & & & & $\mathrm{~S}$ & & \\
\hline USGS 53 (6 to 4 inch @30ft) & $\mathrm{P}$ & & & & PS & & & & & & $\mathrm{S}$ & & \\
\hline USGS 54 & $\mathrm{P}$ & PQ & & PQ & & & & $\mathrm{PQ}$ & & & $\mathrm{S}$ & & \\
\hline USGS 55 & $\mathrm{P}$ & $\mathrm{PQ}$ & & & $\mathrm{S}$ & & & $\mathrm{PQ}$ & & & PQ & & \\
\hline USGS 56 & $\mathrm{P}$ & & & & & & & & & & $\mathrm{S}$ & & \\
\hline USGS 57 & $\mathrm{~A}$ & $\mathrm{AQ}$ & & & $\mathrm{AQ}$ & & & $\mathrm{AQ}$ & & & $\mathrm{S}$ & & \\
\hline USGS 58 & $\mathrm{~A}$ & & & & $\mathrm{~S}$ & & & & & & & & \\
\hline USGS 59 & A & & & & $\mathrm{S}$ & & & & & & $\mathrm{AQ}$ & & \\
\hline USGS 60 & $\mathrm{P}$ & $\mathrm{PQ}$ & & & PQ & & & $\mathrm{PQ}$ & & & $\mathrm{S}$ & & \\
\hline USGS 61 & $\mathrm{P}$ & $\mathrm{PQ}$ & & & $\mathrm{S}$ & & & $\mathrm{PQ}$ & & & $\mathrm{PQ}$ & & \\
\hline USGS 62 & $\mathrm{P}$ & $\mathrm{PQ}$ & & & $\mathrm{S}$ & & & $\mathrm{PQ}$ & & & $\mathrm{PQ}$ & & \\
\hline USGS 63 & $\mathrm{P}$ & PQ & & & PQ & & & $\mathrm{PQ}$ & & & $\mathrm{S}$ & & \\
\hline USGS 65 & $\mathrm{~A}$ & $\mathrm{AQ}$ & & & $\mathrm{S}$ & & & $\mathrm{AQ}$ & & & $\mathrm{AQ}$ & & \\
\hline USGS 66 & $\mathrm{P}$ & PQ & & & PQ & & & PQ & & & $\mathrm{S}$ & & \\
\hline USGS 67 & A & & & $\mathrm{AS}$ & & & & & & & S & & \\
\hline USGS 68 & $\mathrm{P}$ & $\mathrm{PQ}$ & & & $\mathrm{S}$ & & & $\mathrm{PQ}$ & & & PQ & & \\
\hline USGS 69 & $\mathrm{P}$ & PQ & & & PQ & & & PQ & & & $\mathrm{S}$ & & \\
\hline USGS 70 & $\mathrm{P}$ & PQ & & & $\mathrm{S}$ & & & PQ & & & PQ & & \\
\hline USGS 71 & $\mathrm{P}$ & $\mathrm{PQ}$ & & & PQ & & & PQ & & & $\mathrm{S}$ & & \\
\hline USGS 72 & $\mathrm{P}$ & PQ & & & $\mathrm{S}$ & & & PQ & & & PQ & & \\
\hline USGS 73 & $\mathrm{P}$ & $\mathrm{PQ}$ & & & PQ & & & $\mathrm{PQ}$ & & & $\mathrm{S}$ & & \\
\hline USGS 76 & $\mathrm{~A}$ & & & & $\mathrm{~S}$ & & & & & & & & \\
\hline USGS 77 & $\mathrm{~A}$ & & & & & & & & & & $\mathrm{~S}$ & & \\
\hline USGS 78 & $\mathrm{P}$ & $\mathrm{PM}$ & PM & $\mathrm{PM}$ & $\mathrm{PM}$ & PM & $\mathrm{PM}$ & $\mathrm{PM}$ & PM & $\mathrm{PM}$ & $\mathrm{S}$ & $\mathrm{PM}$ & PM \\
\hline USGS 79 & $\mathrm{~A}$ & & & & $\mathrm{~S}$ & & & & & & $\mathrm{AS}$ & & \\
\hline
\end{tabular}




\begin{tabular}{|c|c|c|c|c|c|c|c|c|c|c|c|c|c|}
\hline WELL NAME & Type & Jan & Feb & Mar & Apr & May & Jun & Jul & Aug & Sep & Oct & Nov & Dec \\
\hline USGS 82 & $\mathrm{~A}$ & $\mathrm{AQ}$ & & & $\mathrm{S}$ & & & $\mathrm{AQ}$ & & & $\mathrm{AQ}$ & & \\
\hline USGS 83 & $\mathrm{~A}$ & $\mathrm{AQ}$ & & & $\mathrm{AQ}$ & & & $\mathrm{AQ}$ & & & $\mathrm{AQ}$ & & \\
\hline USGS 84 & $\mathrm{~A}$ & $\mathrm{AQ}$ & & & $\mathrm{AQ}$ & & & $\mathrm{AQ}$ & & & $\mathrm{S}$ & & \\
\hline USGS 85 & $\mathrm{~A}$ & $\mathrm{AQ}$ & & & $\mathrm{S}$ & & & $\mathrm{AQ}$ & & & $\mathrm{AQ}$ & & \\
\hline USGS 86 & $\mathrm{~A}$ & $\mathrm{AQ}$ & & & $\mathrm{AQ}$ & & & $\mathrm{AQ}$ & & & $\mathrm{S}$ & & \\
\hline USGS 87 & $\mathrm{~A}$ & & & & $\mathrm{~S}$ & & & & & & & & \\
\hline USGS 88 & $\mathrm{~A}$ & & & & & & & & & & $\mathrm{~S}$ & & \\
\hline USGS 89 & $\mathrm{~A}$ & $\mathrm{AQ}$ & & & $\mathrm{S}$ & & & $\mathrm{AQ}$ & & & $\mathrm{AQ}$ & & \\
\hline USGS 92 & $\mathrm{P}$ & $\mathrm{PQ}$ & & & $\mathrm{S}$ & & & PQ & & & PQ & & \\
\hline USGS 97 & $\mathrm{~A}$ & $\mathrm{AM}$ & $\mathrm{AM}$ & $\mathrm{AM}$ & $\mathrm{S}$ & ANRF & $\mathrm{AM}$ & $\mathrm{AM}$ & $\mathrm{AM}$ & $\mathrm{AM}$ & $\mathrm{AM}$ & ANRF & $\mathrm{AM}$ \\
\hline USGS 98 & $\mathrm{~A}$ & & & & & ANRF & & & & & $\mathrm{S}$ & ANRF & \\
\hline USGS 99 & $\mathrm{~A}$ & & & & & ANRF & & & & & $\mathrm{S}$ & ANRF & \\
\hline USGS 100 & $\mathrm{~A}$ & $\mathrm{AQ}$ & & & $\mathrm{S}$ & & & $\mathrm{AQ}$ & & & $\mathrm{AQ}$ & & \\
\hline USGS 101 & $\mathrm{~A}$ & $\mathrm{AQ}$ & & & $\mathrm{AQ}$ & & & $\mathrm{AQ}$ & & & $\mathrm{S}$ & & \\
\hline USGS 102 & $\mathrm{~A}$ & & & & $\mathrm{~S}$ & $\mathrm{~S}$ & & & & & & $\mathrm{~S}$ & \\
\hline USGS 104 & $\mathrm{~A}$ & $\mathrm{AQ}$ & & & $\mathrm{AQ}$ & & & $\mathrm{AQ}$ & & & $\mathrm{S}$ & & \\
\hline USGS 106 & $\mathrm{~A}$ & & & $\mathrm{AS}$ & & & & & & & $\mathrm{S}$ & & \\
\hline USGS 107 & $\mathrm{~A}$ & & & & $\mathrm{~S}$ & & & & & & $\mathrm{AS}$ & & \\
\hline USGS 109 & $\mathrm{~A}$ & & & & AA & & & & & & & & \\
\hline USGS 110A & $\mathrm{A}$ & & & & $\mathrm{AS}$ & & & & & & $\mathrm{S}$ & & \\
\hline USGS 111 & $\mathrm{~A}$ & & & & $\mathrm{~S}$ & & & & & & & & \\
\hline USGS 112 & $\mathrm{~A}$ & & & $\mathrm{AS}$ & & & & & & & $\mathrm{S}$ & & \\
\hline USGS 113 & $\mathrm{~A}$ & & & & $\mathrm{~S}$ & & & & & & & & \\
\hline USGS 114 & A & & & & & & & & & & $\mathrm{S}$ & & \\
\hline USGS 115 & $\mathrm{~A}$ & & & & & & & & & & $\mathrm{~S}$ & & \\
\hline USGS 116 & $\mathrm{~A}$ & $\mathrm{AQ}$ & & & $\mathrm{S}$ & & & $\mathrm{AQ}$ & & & $\mathrm{AQ}$ & & \\
\hline USGS 117 & $\mathrm{~A}$ & & & & $\mathrm{AS}$ & & & & & & $\mathrm{S}$ & & \\
\hline USGS 119 & $\mathrm{~A}$ & & & & $\mathrm{~S}$ & & & & & & & & \\
\hline USGS 120 & $\mathrm{~A}$ & $\mathrm{AM}$ & $\mathrm{AM}$ & $\mathrm{AM}$ & AM & $\mathrm{AM}$ & $\mathrm{AM}$ & $\mathrm{AM}$ & $\mathrm{AM}$ & $\mathrm{AM}$ & $\mathrm{S}$ & $\mathrm{AM}$ & $\mathrm{AM}$ \\
\hline USGS 121 & $\mathrm{~A}$ & & & & $\mathrm{AA}$ & & & & & & & & \\
\hline USGS 123 & $\mathrm{~A}$ & & & & & & & & & & $\mathrm{~S}$ & & \\
\hline USGS 124 & $\mathrm{~A}$ & & & & $\mathrm{~S}$ & & & & & & $\mathrm{AS}$ & & \\
\hline USGS 125 & $\mathrm{~A}$ & $\mathrm{AQ}$ & & & $\mathrm{AQ}$ & & & $\mathrm{AQ}$ & & & $\mathrm{AQ}$ & & \\
\hline USGS 126B & $\mathrm{A}$ & $\mathrm{AQ}$ & & & $\mathrm{AQ}$ & & & $\mathrm{AQ}$ & & & $\mathrm{AQ}$ & & \\
\hline USGS 127 & $\mathrm{~A}$ & $\mathrm{AQ}$ & & & $\mathrm{S}$ & & & $\mathrm{AQ}$ & & & $\mathrm{AQ}$ & & \\
\hline USGS 128 & $\mathrm{~A}$ & & & $\mathrm{AS}$ & & & & & & & $\mathrm{S}$ & & \\
\hline USGS 129 & $\mathrm{~A}$ & & & $\mathrm{AQ}$ & & & $\mathrm{AQ}$ & & & $\mathrm{AQ}$ & & & $\mathrm{AQ}$ \\
\hline USGS 130 & $\mathrm{~A}$ & $\mathrm{AQ}$ & & & $\mathrm{AQ}$ & & & $\mathrm{AQ}$ & & & $\mathrm{S}$ & & \\
\hline
\end{tabular}




\begin{tabular}{|c|c|c|c|c|c|c|c|c|c|c|c|c|c|}
\hline WELL NAME & Type & Jan & Feb & Mar & Apr & May & Jun & Jul & Aug & Sep & Oct & Nov & Dec \\
\hline USGS 131 & $\mathrm{~A}$ & & & & $\mathrm{AA}$ & & & & & & & & \\
\hline USGS 136 & $\mathrm{~A}$ & & & & & & & & & & $\mathrm{~S}$ & & \\
\hline USGS 138 & A & & $\mathrm{R}$ & & & $\mathrm{R}$ & & & $\mathrm{R}$ & & & $\mathrm{R}$ & \\
\hline USGS 139A & $\mathrm{A}$ & $\mathrm{AQ}$ & & & $\mathrm{AQ}$ & & & $\mathrm{AQ}$ & & & $\mathrm{AQ}$ & & \\
\hline USGS 139B & $\mathrm{A}$ & $\mathrm{AQ}$ & & & $\mathrm{AQ}$ & & & $\mathrm{AQ}$ & & & $\mathrm{AQ}$ & & \\
\hline USGS 140 & $\mathrm{~A}$ & & & & & & & & & & $\mathrm{~S}$ & & \\
\hline USGS 142 & $\mathrm{~A}$ & $\mathrm{AM}$ & $\mathrm{AM}$ & $\mathrm{AM}$ & $\mathrm{AM}$ & $\mathrm{AM}$ & AM & $\mathrm{AM}$ & $\mathrm{AM}$ & $\mathrm{AM}$ & $\mathrm{AM}$ & $\mathrm{AM}$ & $\mathrm{AM}$ \\
\hline USGS 142A & $\mathrm{A}$ & $\mathrm{AM}$ & $\mathrm{AM}$ & $\mathrm{AM}$ & $\mathrm{AM}$ & $\mathrm{AM}$ & AM & $\mathrm{AM}$ & AM & $\mathrm{AM}$ & $\mathrm{AM}$ & $\mathrm{AM}$ & $\mathrm{AM}$ \\
\hline USGS 143 & $\mathrm{~A}$ & $\mathrm{AQ}$ & & & $\mathrm{S}$ & & & $\mathrm{AQ}$ & & & $\mathrm{AQ}$ & & \\
\hline USGS 144 & $\mathrm{~A}$ & & & & $\mathrm{~S}$ & & & & & & & & \\
\hline USGS 145A & $\mathrm{A}$ & $\mathrm{AM}$ & $\mathrm{AM}$ & $\mathrm{AM}$ & $\mathrm{AM}$ & $\mathrm{AM}$ & AM & $\mathrm{AM}$ & $\mathrm{AM}$ & $\mathrm{AM}$ & $\mathrm{AM}$ & $\mathrm{AM}$ & $\mathrm{AM}$ \\
\hline USGS 145B & $\mathrm{A}$ & $\mathrm{AM}$ & $\mathrm{AM}$ & $\mathrm{AM}$ & $\mathrm{AM}$ & $\mathrm{AM}$ & AM & $\mathrm{AM}$ & $\mathrm{AM}$ & $\mathrm{AM}$ & $\mathrm{AM}$ & $\mathrm{AM}$ & $\mathrm{AM}$ \\
\hline USGS 146 & $\mathrm{~A}$ & & & & $\mathrm{AS}$ & & & & & & $\mathrm{S}$ & & \\
\hline USGS 147 & $\mathrm{~A}$ & $\mathrm{AM}$ & $\mathrm{AM}$ & $\mathrm{AM}$ & $\mathrm{S}$ & $\mathrm{AM}$ & $\mathrm{AM}$ & $\mathrm{AM}$ & $\mathrm{AM}$ & $\mathrm{AM}$ & $\mathrm{AM}$ & $\mathrm{AM}$ & $\mathrm{AM}$ \\
\hline USGS 148A & $\mathrm{A}$ & $\mathrm{AM}$ & $\mathrm{AM}$ & $\mathrm{AM}$ & $\mathrm{AM}$ & $\mathrm{AM}$ & AM & $\mathrm{AM}$ & AM & $\mathrm{AM}$ & $\mathrm{AM}$ & $\mathrm{AM}$ & $\mathrm{AM}$ \\
\hline A11A31 & $\mathrm{A}$ & & & $\mathrm{AA}$ & & & & & & & & & \\
\hline ANL MON A 014 & $\mathrm{~A}$ & & & $\mathrm{AA}$ & & & & & & & & & \\
\hline ANP 5 & $\mathrm{~A}$ & & & & $\mathrm{AA}$ & & & & & & & & \\
\hline ANP 6 & $\mathrm{~A}$ & & & & $\mathrm{AS}$ & & & & & & $\mathrm{S}$ & & \\
\hline ANP 7 & $\mathrm{~A}$ & & & & $\mathrm{AA}$ & & & & & & & & \\
\hline ANP 9 & $\mathrm{~A}$ & $\mathrm{AQ}$ & & & $\mathrm{AQ}$ & & & $\mathrm{AQ}$ & & & $\mathrm{AQ}$ & & \\
\hline ANP 10 & $\mathrm{~A}$ & & & & $\mathrm{AA}$ & & & & & & & & \\
\hline ARA-MON-A-002 & $\mathrm{A}$ & $\mathrm{AQ}$ & & & $\mathrm{AQ}$ & & & $\mathrm{AQ}$ & & & $\mathrm{S}$ & & \\
\hline ARBOR TEST & $\mathrm{A}$ & $\mathrm{AQ}$ & & & $\mathrm{AQ}$ & & & $\mathrm{AQ}$ & & & $\mathrm{AQ}$ & & \\
\hline AREA 2 & $\mathrm{~A}$ & & & & $\mathrm{AS}$ & & & & & & $\mathrm{S}$ & & \\
\hline CERRO GRANDE & $\mathrm{A}$ & & & $\mathrm{AA}$ & & & & & & & & & \\
\hline CFA 1932 & $\mathrm{~A}$ & & & $\mathrm{AS}$ & & & & & & & $\mathrm{AS}$ & & \\
\hline CFA LF 2-10 & $\mathrm{A}$ & $\mathrm{AQ}$ & & & $\mathrm{S}$ & & & $\mathrm{AQ}$ & & & $\mathrm{AQ}$ & & \\
\hline CFA LF 2-11 & $\mathrm{A}$ & & & $\mathrm{AA}$ & & & & & & & & & \\
\hline COREHOLE 1 & $\mathrm{~A}$ & $\mathrm{AQ}$ & & $\mathrm{AQ}$ & & & & $\mathrm{AQ}$ & & & $\mathrm{AQ}$ & & \\
\hline COREHOLE 2A & $\mathrm{A}$ & $\mathrm{AQ}$ & & & $\mathrm{AQ}$ & & & $\mathrm{AQ}$ & & & $\mathrm{AQ}$ & & \\
\hline CWP 1 & $\mathrm{P}$ & & & & $\mathrm{S}$ & & & & & & & & \\
\hline CWP 2 & $\mathrm{P}$ & & & & PA & & & & & & & & \\
\hline CWP 3 & $\mathrm{P}$ & & & & PA & & & & & & & & \\
\hline CWP 4 & $\mathrm{P}$ & & & & PA & & & & & & & & \\
\hline CWP 5 & $\mathrm{P}$ & & & & PA & & & & & & & & \\
\hline CWP 6 & $\mathrm{P}$ & & & & PA & & & & & & & & \\
\hline CWP 7 & $\mathrm{P}$ & & & & PA & & & & & & & & \\
\hline
\end{tabular}




\begin{tabular}{|c|c|c|c|c|c|c|c|c|c|c|c|c|c|}
\hline WELL NAME & Type & Jan & Feb & Mar & Apr & May & Jun & Jul & Aug & Sep & Oct & Nov & Dec \\
\hline CWP 8 & $\mathrm{P}$ & & & & $\mathrm{S}$ & & & & & & & & \\
\hline CWP 9 & $\mathrm{P}$ & & & & PA & & & & & & & & \\
\hline DH 1B & $\mathrm{A}$ & & & $\mathrm{AQ}$ & & & $\mathrm{AQ}$ & & & $\mathrm{AQ}$ & & & $\mathrm{AQ}$ \\
\hline DH $2 \mathrm{~A}$ & $\mathrm{~A}$ & & & $\mathrm{AQ}$ & & & $\mathrm{AQ}$ & & & $\mathrm{AQ}$ & & & $\mathrm{AQ}$ \\
\hline FIRE STATION 2 & $\mathrm{~A}$ & & & $\mathrm{AQ}$ & & & $\mathrm{AQ}$ & & & $\mathrm{AQ}$ & & & $\mathrm{AQ}$ \\
\hline GIN 2 No wl sample only & $\mathrm{A}$ & & & & & & & & & & $\mathrm{S}$ & & \\
\hline GIN 3 & $\mathrm{~A}$ & & & $\mathrm{AA}$ & & & & & & & & & \\
\hline HWY 1A PIEZO 3 & A & & & $\mathrm{AQ}$ & & & $\mathrm{AQ}$ & & & $\mathrm{AQ}$ & & & $\mathrm{AQ}$ \\
\hline HWY 1B PIEZO 2 & $\mathrm{~A}$ & & & $\mathrm{AQ}$ & & & $\mathrm{AQ}$ & & & $\mathrm{AQ}$ & & & $\mathrm{AQ}$ \\
\hline HWY 1C PIEZO 1 & $\mathrm{~A}$ & & & $\mathrm{AQ}$ & & & $\mathrm{AQ}$ & & & $\mathrm{AQ}$ & & & $\mathrm{AQ}$ \\
\hline HWY 2 & $\mathrm{~A}$ & & & $\mathrm{AQ}$ & & & $\mathrm{AQ}$ & & & $\mathrm{AQ}$ & & & $\mathrm{AQ}$ \\
\hline ICPP-MON-A-166 & $\mathrm{A}$ & $\mathrm{AQ}$ & & & $\mathrm{S}$ & & & $\mathrm{AQ}$ & & & $\mathrm{AQ}$ & & \\
\hline ICPP-MON-V-200 & $\mathrm{P}$ & PQ & & & PQ & & & PQ & & & $\mathrm{S}$ & & \\
\hline INEL 1 & $\mathrm{~A}$ & & & $\mathrm{AA}$ & & & & & & & & & \\
\hline MTR TEST & $\mathrm{A}$ & $\mathrm{AM}$ & $\mathrm{AM}$ & $\mathrm{AM}$ & $\mathrm{S}$ & $\mathrm{AM}$ & $\mathrm{AM}$ & $\mathrm{AM}$ & $\mathrm{AM}$ & $\mathrm{AM}$ & $\mathrm{AM}$ & $\mathrm{AM}$ & $\mathrm{AM}$ \\
\hline NO NAME 1 & $\mathrm{~A}$ & $\mathrm{AQ}$ & & & $\mathrm{S}$ & & & $\mathrm{AQ}$ & & & $\mathrm{AQ}$ & & \\
\hline NPR TEST & $\mathrm{A}$ & $\mathrm{AQ}$ & & & $\mathrm{AQ}$ & & & $\mathrm{AQ}$ & & & $\mathrm{S}$ & & \\
\hline NRF 2 & $\mathrm{~A}$ & & & & & ANRF & & & & & & ANRF & \\
\hline NRF 3 & $\mathrm{~A}$ & & & & & $\mathrm{~S}$ & & & & & & $\mathrm{~S}$ & \\
\hline NRF 5 & $\mathrm{~A}$ & & & & & ANRF & & & & & & ANRF & \\
\hline NRF 6 & $\mathrm{~A}$ & & & & & $\mathrm{~S}$ & & & & & & $\mathrm{~S}$ & \\
\hline NRF 7 & $\mathrm{~A}$ & & & & & $\mathrm{~S}$ & & & & & & $\mathrm{~S}$ & \\
\hline NRF 8 & $\mathrm{~A}$ & & & & & $\mathrm{~S}$ & & & & & & $\mathrm{~S}$ & \\
\hline NRF 9 & $\mathrm{~A}$ & & & & & $\mathrm{~S}$ & & & & & & $\mathrm{~S}$ & \\
\hline NRF 10 & $\mathrm{~A}$ & & & & & $\mathrm{~S}$ & & & & & & $\mathrm{~S}$ & \\
\hline NRF 11 & $\mathrm{~A}$ & & & & & $\mathrm{~S}$ & & & & & & $\mathrm{~S}$ & \\
\hline NRF 12 & $\mathrm{~A}$ & & & & & $\mathrm{~S}$ & & & & & & $S$ & \\
\hline NRF 13 & $\mathrm{~A}$ & & & & & ANRF & & & & & & ANRF & \\
\hline NRF 14 & $\mathrm{~A}$ & & & & & $\mathrm{~S}$ & & & & & & $\mathrm{~S}$ & \\
\hline NRF 15-A & $\mathrm{A}$ & $\mathrm{AM}$ & $\mathrm{AM}$ & $\mathrm{AM}$ & $\mathrm{AM}$ & $\mathrm{AM}$ & AM & $\mathrm{AM}$ & $\mathrm{AM}$ & $\mathrm{AM}$ & $\mathrm{AM}$ & $\mathrm{AM}$ & $\mathrm{AM}$ \\
\hline NRF 15-B & $\mathrm{A}$ & AM & $\mathrm{AM}$ & $\mathrm{AM}$ & $\mathrm{AM}$ & AM & AM & $\mathrm{AM}$ & $\mathrm{AM}$ & $\mathrm{AM}$ & $\mathrm{AM}$ & AM & $\mathrm{AM}$ \\
\hline NRF 16 & $\mathrm{~A}$ & & & & & $\mathrm{~S}$ & & & & & & $\mathrm{~S}$ & \\
\hline PandW 1 & $\mathrm{~A}$ & & & & $\mathrm{AA}$ & & & & & & & & \\
\hline PandW 2 & $\mathrm{~A}$ & & & & $\mathrm{~S}$ & & & & & & $\mathrm{AS}$ & & \\
\hline PandW 3 & $\mathrm{~A}$ & & & & $\mathrm{AA}$ & & & & & & & & \\
\hline PBF-MON-A-003 & $\mathrm{A}$ & & & $\mathrm{AS}$ & & & & & & & $\mathrm{S}$ & & \\
\hline PSTF TEST & $\mathrm{A}$ & & & & $\mathrm{AS}$ & & & & & & $\mathrm{AS}$ & & \\
\hline PW 8 & $\mathrm{P}$ & PQ & & & $\mathrm{S}$ & & & PQ & & & $\mathrm{PQ}$ & & \\
\hline
\end{tabular}




\begin{tabular}{|c|c|c|c|c|c|c|c|c|c|c|c|c|c|}
\hline WELL NAME & Type & Jan & Feb & Mar & Apr & May & Jun & Jul & Aug & Sep & Oct & Nov & Dec \\
\hline PW 9 & $\mathrm{P}$ & PQ & & & $P Q$ & & & PQ & & & $\mathrm{S}$ & & \\
\hline RWMC M3S & $\mathrm{A}$ & & & & $\mathrm{AS}$ & & & & & & $\mathrm{S}$ & & \\
\hline RWMC M6S & $\mathrm{A}$ & & & & $\mathrm{AA}$ & & & & & & & & \\
\hline RWMC M7S & $\mathrm{A}$ & & & & $\mathrm{AS}$ & & & & & & $\mathrm{S}$ & & \\
\hline RWMC M12S & $\mathrm{A}$ & & & & $\mathrm{AS}$ & & & & & & $\mathrm{S}$ & & \\
\hline RWMC M14S & $\mathrm{A}$ & & & & $\mathrm{AS}$ & & & & & & $\mathrm{S}$ & & \\
\hline SITE 6 & $\mathrm{~A}$ & & & & & $\mathrm{~S}$ & & & & & & $\mathrm{~S}$ & \\
\hline SITE 9 & A & $\mathrm{AQ}$ & & & $\mathrm{S}$ & & & $\mathrm{AQ}$ & & & $\mathrm{AQ}$ & & \\
\hline SITE 14 & $\mathrm{~A}$ & $\mathrm{AQ}$ & & & $\mathrm{AQ}$ & & & $\mathrm{AQ}$ & & & $\mathrm{S}$ & & \\
\hline SITE 15 & $\mathrm{~A}$ & & & & $\mathrm{AA}$ & & & & & & & & \\
\hline SITE 17 & $\mathrm{~A}$ & & $\mathrm{R}$ & & $\mathrm{S}$ & $\mathrm{S}$ & & & $\mathrm{R}$ & & & $\mathrm{S}$ & \\
\hline SITE 19 & $\mathrm{~A}$ & & & $\mathrm{AS}$ & & & & & & & $\mathrm{AS}$ & & \\
\hline TAN CH 2 piezo B & $\mathrm{A}$ & & & $\mathrm{AQ}$ & & & $\mathrm{AQ}$ & & & $\mathrm{AQ}$ & & & $\mathrm{AQ}$ \\
\hline TAN 14 & $\mathrm{~A}$ & & & $\mathrm{AS}$ & & & & & & $\mathrm{AS}$ & & & \\
\hline TAN 15 & $\mathrm{~A}$ & & & $\mathrm{AS}$ & & & & & & $\mathrm{AS}$ & & & \\
\hline TAN 17 & $\mathrm{~A}$ & & & $\mathrm{AQ}$ & & & $\mathrm{AQ}$ & & & $\mathrm{AQ}$ & & & $\mathrm{AQ}$ \\
\hline TAN 2271 No wl sample only & $\mathrm{A}$ & & & & & & & & & & $\mathrm{S}$ & & \\
\hline TAN 2312 & A & & & & $\mathrm{AS}$ & & & & & & $\mathrm{S}$ & & \\
\hline TRA DISP & $\mathrm{A}$ & & & & & & & & & & $\mathrm{S}$ & & \\
\hline WS INEL 1 & $\mathrm{~A}$ & & & & $\mathrm{~S}$ & & & & & & $\mathrm{AS}$ & & \\
\hline 04N 35E 31DAA1 & $\mathrm{A}$ & & & & AA & & & & & & & & \\
\hline 02N 26E 22DDA1 & $\mathrm{A}$ & & & & $\mathrm{AA}$ & & & & & & & & \\
\hline 02N 26E 22DDA2 & A & & & & $\mathrm{AA}$ & & & & & & & & \\
\hline \multicolumn{14}{|l|}{ RMS entery needed } \\
\hline Monthly totals & & 79 & 23 & 47 & 132 & 39 & 26 & 76 & 23 & 29 & 124 & 40 & 26 \\
\hline Sampled wells & & 0 & 0 & 0 & 60 & 14 & 0 & 0 & 0 & 0 & 57 & 14 & 0 \\
\hline W/L's only & & 79 & 23 & 47 & 72 & 25 & 26 & 76 & 23 & 29 & 67 & 26 & 26 \\
\hline TOTAL PERCHED & 29 & & & & & & & & & & & & \\
\hline TOTAL AQUIFER & 174 & & & & & & & & & & & & \\
\hline TOTAL WELLS & 203 & & & & & & & & & & & & \\
\hline
\end{tabular}




\section{Appendix 3. Data-Quality Objectives for Routine Water Samples Analyzed by the National Water Quality Laboratory}

Table 3.1. Data-quality objectives for routine water samples analyzed by the National Water Quality Laboratory.

[Accuracy: Coefficient of variance measured by replicate analysis. Abbreviations: N, nitrogen; P, phosphorus; $\mu \mathrm{g} / \mathrm{L}$, micrograms per liter]

\begin{tabular}{lcccl}
\hline \multicolumn{1}{c}{ Constituent } & $\begin{array}{c}\text { Reporting level } \\
(\boldsymbol{\mu g} / \mathbf{L})\end{array}$ & $\begin{array}{c}\text { Precision } \\
(+/ \text { - percent) }\end{array}$ & $\begin{array}{c}\text { Accuracy } \\
\text { (percent) }\end{array}$ & Lab code/schedule \\
\hline I. Volatile organic compounds & Variable & 30 & $70-130$ & SH 1380 \\
II. Inorganic compounds & & & & \\
$\quad$ (filtered): & 3.0 & 10 & $90-110$ & SH 1050 \\
Aluminum & 0.06 & 10 & $90-110$ & SH 1050 \\
Antimony & 0.1 & 10 & $90-110$ & LC 3122 \\
Arsenic & 0.6 & 10 & $90-110$ & SH 1050 \\
Barium & 0.01 & 10 & $90-110$ & SH 1050 \\
Beryllium & 2.0 & 10 & $90-110$ & LC 2110 \\
Boron & 10 & 10 & $90-110$ & SH 670 \\
Bromide & 0.03 & 10 & $90-110$ & SH 1050 \\
Cadmium & 22 & 10 & $90-110$ & SH 2126 \\
Calcium & 20 & 10 & $90-110$ & LC 1571 \\
Chloride & 0.6 & 10 & $90-110$ & LC 722 \\
Chromium & 0.03 & 10 & $90-110$ & SH 1050 \\
Cobalt & 0.4 & 10 & $90-110$ & SH 1050 \\
Copper & 10 & 10 & $90-110$ & LC 651 \\
Fluoride & 10 & 10 & $90-110$ & SH 2126 \\
Iron & 0.02 & 10 & $90-110$ & SH 1050 \\
Lead & 0.15 & 10 & $90-110$ & SH 2126 \\
Lithium & 0.01 & 10 & $90-110$ & SH 2126 \\
Magnesium & 0.40 & 10 & $90-110$ & SH 1050 \\
Manganese & 0.005 & 10 & $90-110$ & LC 2707 \\
Mercury & 0.05 & 10 & $90-110$ & SH 1050 \\
Molybdenum & 0.20 & 10 & $90-110$ & SH 1050 \\
Nickel & 300 & 10 & $90-110$ & SH 2126 \\
Potassium & 0.05 & 10 & $90-110$ & LC 3132 \\
Selenium & 50 & 10 & $90-110$ & SH 2126 \\
Silica & 1.0 & 10 & $90-110$ & SH 1050 \\
Silver & 200 & 10 & $90-110$ & LC 675 \\
Sodium & 0.5 & 10 & $90-110$ & SH 2126 \\
Strontium & 20 & 10 & $90-110$ & LC 1572 \\
Sulfate & 0.04 & 10 & $90-110$ & LC 2508 \\
Thallium & 0.03 & 10 & $90-110$ & SH 2126 \\
Tungsten & 0.03 & 10 & $90-110$ & SH 1050 \\
Uranium & 0.1 & 10 & $90-110$ & SH 2126 \\
Vanadium & 2.0 & 10 & $90-110$ & SH 1050 \\
Zinc & 1.0 & 40 & $60-140$ & SH 101 \\
Ammonia (as N) & 10 & 10 & $90-110$ & SH 101 \\
Nitrite (as N) & 10 & $90-110$ & SH 101 \\
Nitrite + Nitrate (as N) & SH 101 \\
Orthophosphate (as P) & & & &
\end{tabular}




\section{Appendix 4. Data-Quality Objectives for Radionuclides in Water Samples Analyzed by the Radiological and Environmental Sciences Laboratory}

For each radionuclide concentration, an associated analytical uncertainty $(s)$ is calculated such that there is a 67-percent probability that the true concentration of a radionuclide in a sample is in the range of the reported concentration plus or minus the analytical uncertainty. For example, given an analytical result of $1.0 \pm 0.2 \mathrm{pCi} / \mathrm{L}$ (picocuries per liter), there is a 67-percent probability that the true concentration is in the range of 0.8 to $1.2 \mathrm{pCi} / \mathrm{L}$. Some laboratories report the analytical uncertainty as $2 s$, at which there is a 95 -percent probability that the true concentration is in the range of $0.6-1.4 \mathrm{pCi} / \mathrm{L}$. Therefore, unlike analyses for most inorganic or organic constituents, the analytical uncertainty is specified for each analysis for a specified radionuclide. The following guidelines for interpreting analytical results are based on an extension of the method described by Currie (1968).

In the analysis for a selected radionuclide, laboratory measurements are made on a target sample and a prepared blank. Instrument signals for the sample and the blank vary randomly. Therefore, it is essential to distinguish between two key aspects of the problem of detection: (1) the instrument signal for the sample must be greater than the signal observed for the blank to make the decision that a selected radionuclide was detected; and (2) an estimation must be made of the minimum radionuclide concentration that will yield a sufficiently large observed signal to make the correct decision of detection or nondetection of that radionuclide most of the time. The first aspect of the problem is a qualitative decision based on an observed signal and a definite criterion for detection. The second aspect of the problem is an intuitive estimation of the detection capabilities of a given measurement process.

In the laboratory, instrument signals must exceed a critical level to make the qualitative decision whether a selected radionuclide was detected. Radionuclide concentrations that equal $1.6 \mathrm{~s}$ meet this criterion; at $1.6 \mathrm{~s}$, there is a 95-percent probability that the correct decision-not detected-will be made. Given a large number of samples, up to 5 percent of the samples with true concentrations greater than or equal to $1.6 \mathrm{~s}$, which were concluded as being detected, might not contain the selected radionuclide. These measurements are referred to as false positives and are errors of the first kind in hypothesis testing.

Once the critical level of $1.6 \mathrm{~s}$ has been defined, the minimum detectable concentration may be established. Radionuclide concentrations that equal $3 s$ represent a measurement of the minimum detectable concentration. For true concentrations of $3 \boldsymbol{s}$ or greater, there is a 95-percentor-more probability of correctly concluding that a selected radionuclide was detected in a sample. Given a large number of samples, up to 5 percent of the samples with true concentrations greater than or equal to $3 s$, which were concluded as being nondetected, could contain the selected radionuclide at the minimum detectable concentration. These measurements are referred to as false negatives and are errors of the second kind in hypothesis testing. Inclusion of the $3 \mathbf{s}$ criterion reduces the probability of a false negative to 5 percent or less.

True radionuclide concentrations between $1.6 \mathrm{~s}$ and $3 \mathrm{~s}$ have larger errors of the second kind. That is, there is a greater-than-5-percent probability of false negative results for samples with true concentrations between $1.6 s$ and $3 s$, and although the selected radionuclide might not have been detected, such nondetection may not be reliable; at $1.6 \mathrm{~s}$, the probability of false negative is about 50 percent.

These guidelines are based on counting statistics alone and do not include systematic or random errors inherent in laboratory procedures. The values $1.6 \mathrm{~s}$ and $3 \mathrm{~s}$ vary slightly with 
background or blank counts and with the number of gross counts for individual analyses and for different selected radionuclides. The use of the critical level and minimum detectable concentration aid in the interpretation of analytical results and do not represent absolute concentrations of radioactivity which may or may not have been detected. The minimum detectable concentration should not be confused with the detection limit, which is based on instrument sensitivity, sample volumes, analytical procedures and counting times used in the laboratory.

Bodnar and Percival (1982) summarized detection limits normally available from the Radiological and Environmental Sciences Laboratory. Special arrangements can be made to achieve smaller detection limits for selected constituents. For example, by using a 5-fold counting time for tritium in water, that is, increasing the counting time from 20 to 100 minutes, the detection limit can be reduced from 500 to $200 \mathrm{pCi} / \mathrm{L}$.

Detection limits for selected types of radioactivity and nuclides as a function of sample size and detection method are shown on table 4.1; the limits are intended as guides to order-ofmagnitude sensitivities and, in practice, can easily change by a factor of two or more even for the conditions specified.

Table 4.1. Data-quality objectives for radionuclides in water samples analyzed by the Radiological and Environmental Sciences Laboratory.

[Data source: Guy Backstrom, U.S. Department of Energy, written commun., 2020. Abbreviations: bkgd, background; HPGe, high purity Germanium radiation detector]

\begin{tabular}{llcccc}
\hline $\begin{array}{c}\text { Type of radioactivity } \\
\text { or nuclide }\end{array}$ & $\begin{array}{c}\text { Sample } \\
\text { material }\end{array}$ & $\begin{array}{c}\text { Size of } \\
\text { sample } \\
\text { (milliliter) }\end{array}$ & $\begin{array}{c}\text { Counting } \\
\text { time } \\
\text { (minutes) }\end{array}$ & $\begin{array}{c}\text { Detection } \\
\text { method or } \\
\text { instrument }\end{array}$ & $\begin{array}{c}\text { Detection limit } \\
\text { (picocuries } \\
\text { per milliliter) }\end{array}$ \\
\hline Gross alpha & Water & 250 & 100 & Low bkgd counter & $3 \times 10^{-3}$ \\
Gross beta & Water & 250 & 100 & Low bkgd counter & $2 \times 10^{-3}$ \\
Strontium-90 & Water & 400 & 200 & Liquid scintillation & $2 \times 10^{-3}$ \\
Tritium & Water & 10 & 100 & Liquid scintillation & 0.2 \\
Thorium-230 & Water & 500 & 1,000 & Alpha spectrometry & $5 \times 10^{-5}$ \\
Uranium-234 & Water & 500 & 1,000 & Alpha spectrometry & $5 \times 10^{-5}$ \\
Plutonium-238+ & Water & 500 & 1,000 & Alpha spectrometry & $5 \times 10^{-5}$ \\
Plutonium-239/240 & & & & & \\
Americium-241 & Water & 500 & 1,000 & Alpha spectrometry & $5 \times 10^{-5}$ \\
Technicium-99 & Water & 400 & 100 & Liquid scintillation & $8 \times 10^{-3}$ \\
Tellurium-132 & Water & 400 & 60 & HPGe & $6 \times 10^{-2}$ \\
Selenium-75 & Water & 400 & 60 & HPGe & $08 \times 10^{-2}$ \\
Antimony-125 & Water & 400 & 60 & HPGe & 0.2 \\
Ruthenium-103 & Water & 400 & 60 & HPGe & $1 \times 10^{-2}$ \\
Thallium-108 & Water & 400 & 60 & HPGe & 0.2 \\
Antimony-124 & Water & 400 & 60 & HPGe & 0.1 \\
Cobalt-60 & Water & 400 & 60 & HPGe & $6 \times 10^{-2}$ \\
Potassium-40 & Water & 400 & 60 & HPGe & 1.0 \\
Cerium-144 & Water & 400 & 60 & HPGe & 0.4 \\
Cerium-141 & Water & 400 & 60 & HPGe & $9 \times 10^{-2}$ \\
Chromium-51 & Water & 400 & 60 & HPGe & 0.6 \\
Iodine-131 & Water & 400 & 60 & HPGe & $6 \times 10^{-2}$ \\
Barium-140 & Water & 400 & 60 & HPGe & 0.2 \\
Ruthenium-106 & Water & 400 & 60 & HPGe & 0.5 \\
Cesium-137 & Water & 400 & 60 & HPGe & $6 \times 10^{-2}$ \\
Cesium-134 & Water & 400 & 60 & HPGe & $6 \times 10^{-2}$ \\
Molybdenum-99 & Water & 400 & 60 & HPGe & $5 \times 10^{-2}$ \\
& & & & &
\end{tabular}




\begin{tabular}{llcccc}
\hline $\begin{array}{c}\text { Type of radioactivity } \\
\text { or nuclide }\end{array}$ & $\begin{array}{c}\text { Sample } \\
\text { material }\end{array}$ & $\begin{array}{c}\text { Size of } \\
\text { sample } \\
\text { (milliliter) }\end{array}$ & $\begin{array}{c}\text { Counting } \\
\text { time } \\
\text { (minutes) }\end{array}$ & $\begin{array}{c}\text { Detection } \\
\text { method or } \\
\text { instrument }\end{array}$ & $\begin{array}{c}\text { Detection limit } \\
\text { (picocuries } \\
\text { per milliliter) }\end{array}$ \\
\hline Mercury-203 & Water & 400 & 60 & $\mathrm{HPGe}$ & $6 \times 10^{-2}$ \\
Krypton-85 & Water & 400 & 60 & $\mathrm{HPGe}$ & 21 \\
Zirconium-95 & Water & 400 & 60 & $\mathrm{HPGe}$ & $9 \times 10^{-2}$ \\
Cobalt-58 & Water & 400 & 60 & $\mathrm{HPGe}$ & $6 \times 10^{-2}$ \\
Manganese-54 & Water & 400 & 60 & $\mathrm{HPGe}$ & $5 \times 10^{-2}$ \\
Silver-110 & Water & 400 & 60 & $\mathrm{HPGe}$ & $7 \times 10^{-2}$ \\
Actinium-228 & Water & 400 & 60 & $\mathrm{HPGe}$ & 0.2 \\
Iron-59 & Water & 400 & 60 & $\mathrm{HPGe}$ & 0.1 \\
Zinc-65 & Water & 400 & 60 & HPGe & 0.1 \\
\hline
\end{tabular}




\section{Appendix 5. Data-Quality Objectives for Water Samples Analyzed by GEL Laboratories, LLC, TestAmerica Laboratories, and ARS International, LLC}

The EPA (1994) has established six primary analytical data-quality objectives for environmental studies. These objectives are precision, accuracy, representativeness, completeness, comparability, and detectability. GEL Laboratories, LLC approach to each data quality objective is given in a report by GEL Laboratories, LLC (2015). TestAmerica Laboratories' (TAL) approach to each data-quality objective is given in a report by TestAmerica (2013, revision 5). The method of analyses, minimum reporting levels, and method detection limits for constituents analyzed by GEL, TAL and for tritium analysis done at the ARS International, LLC for the U.S. Geological Survey Idaho National Laboratory Project Office are given in table 5.1 .

Table 5.1. Methods for analyses, minimum reporting levels, and method detection limits for constituents analyzed by the GEL Laboratories, LLC, and ARS International, LLC.

[Abbreviations: N, nitrogen; $\mathrm{pCi} / \mathrm{L}$, picocuries per liter; $\mu \mathrm{g} / \mathrm{L}$, micrograms per liter; -, not applicable. Tritium analyses were done by ARS International, LLC.]

\begin{tabular}{|c|c|c|c|}
\hline Constituent & $\begin{array}{l}\text { Method } \\
\text { for } \\
\text { analyses }\end{array}$ & $\begin{array}{c}\text { Reporting } \\
\text { level } \\
(\mu \mathrm{g} / \mathrm{L}) \\
\end{array}$ & $\begin{array}{c}\text { Method } \\
\text { detection limit } \\
(\mu \mathrm{g} / \mathrm{L}) \\
\end{array}$ \\
\hline Volatile organic compounds & 524.2 & Variable & Variable \\
\hline Semi-volatile organic compounds & 525.2 & Variable & Variable \\
\hline \multicolumn{4}{|c|}{ Inorganic compounds } \\
\hline Aluminum & $3010 \mathrm{~A} / 6020 \mathrm{~A}$ & 50.0 & 19.3 \\
\hline Antimony & $3010 \mathrm{~A} / 6020 \mathrm{~A}$ & 3.00 & 1.00 \\
\hline Arsenic & 3010A/6020A & 5.00 & 2.00 \\
\hline Barium & 3010A/6020A & 2.00 & 0.670 \\
\hline Beryllium & $3010 \mathrm{~A} / 6020 \mathrm{~A}$ & 0.5 & 0.2 \\
\hline Cadmium & $3010 \mathrm{~A} / 6020 \mathrm{~A}$ & 1.00 & 0.300 \\
\hline Calcium & $3010 \mathrm{~A} / 6020 \mathrm{~A}$ & 2,000 & 800 \\
\hline Chloride & 300.0 & 1,000 & 335 \\
\hline Chromium & 6020 & 10.0 & 3.0 \\
\hline Copper & $3010 \mathrm{~A} / 6020 \mathrm{~A}$ & 1.00 & 0.300 \\
\hline Iron & 3010A/6020A & 100 & 33.0 \\
\hline Lead & $3010 \mathrm{~A} / 6020 \mathrm{~A}$ & 2.00 & 0.500 \\
\hline Magnesium & $3010 \mathrm{~A} / 6020 \mathrm{~A}$ & 30.0 & 10.0 \\
\hline Manganese & $3010 \mathrm{~A} / 6020 \mathrm{~A}$ & 5.00 & 1.00 \\
\hline Mercury & $7470 \mathrm{~A}$ & 0.200 & 0.0670 \\
\hline Nickel & $3010 \mathrm{~A} / 6020 \mathrm{~A}$ & 2.00 & 0.600 \\
\hline Potassium & $3010 \mathrm{~A} / 6020 \mathrm{~A}$ & 300 & 80.0 \\
\hline Selenium & $3010 \mathrm{~A} / 6020 \mathrm{~A}$ & 5.00 & 2.00 \\
\hline Silver & $3010 \mathrm{~A} / 6020 \mathrm{~A}$ & 1.00 & 0.300 \\
\hline Sodium & $3010 \mathrm{~A} / 6010 \mathrm{~A}$ & 250 & 80.0 \\
\hline Sulfate & 300.0 & 2,000 & 665 \\
\hline Thallium & $3010 \mathrm{~A} / 6020 \mathrm{~A}$ & 2.00 & 0.600 \\
\hline Zinc & $3010 \mathrm{~A} / 6020 \mathrm{~A}$ & 10.0 & 3.3 \\
\hline Nitrite (as N) & 300.0 & 100 & 33.0 \\
\hline Nitrate/Nitrite (as N) & 353.2 & 100 & 35.0 \\
\hline \multicolumn{4}{|c|}{ Radionuclides } \\
\hline Tritium & Liquid scintillation & $3 \mathrm{pCi} / \mathrm{L}$ & - \\
\hline Gamma & 901.1 & $5 \mathrm{pCi} / \mathrm{L}$ & - \\
\hline
\end{tabular}




\begin{tabular}{lccc}
\hline Constituent & $\begin{array}{c}\text { Method } \\
\text { for } \\
\text { analyses }\end{array}$ & $\begin{array}{c}\text { Reporting } \\
\text { level } \\
(\boldsymbol{\mu g} / \mathrm{L})\end{array}$ & $\begin{array}{c}\text { Method } \\
\text { detection limit } \\
(\boldsymbol{\mu g} / \mathrm{L})\end{array}$ \\
\hline Cobalt-60 & 901.1 & $5 \mathrm{pCi} / \mathrm{L}$ & - \\
Nickel-63 & $\begin{array}{l}\text { DOE RESL Ni-1, } \\
\text { Mod }\end{array}$ & $5 \mathrm{pCi} / \mathrm{L}$ & - \\
Strontium-90 & $905.0 \mathrm{Mod}$ & $1 \mathrm{pCi} / \mathrm{L}$ & - \\
\hline
\end{tabular}




\section{Appendix 6. Data-Quality Objectives for Quality Control Data}

Data-quality objectives for quality control data are presented as criteria for acceptable variability (measured as reproducibility and reliability from replicates) and contamination bias (measured from blanks) (Rattray, 2012, 2014).

The reproducibility for a constituent is considered acceptable if:

1. The normalized absolute difference of radiochemical constituents from a replicate is less than or equal to 1.96 ,

2. The relative standard deviation of inorganic and organic constituents from a replicate is less than 14 percent (this corresponds to a relative percent difference of less than 20 percent),

3. Both replicate measurements of a constituent are censored and (or) estimated because they are less than the reporting level for that analysis, or

4. One replicate measurement of a constituent is censored or estimated and the other replicate measurement of the constituent is within one detection limit of the larger of the estimated value or the reporting level, or the replicate measurements of a constituent are within one detection limit of each other.

If the percentage of replicates with acceptable reproducibility for a constituent is greater than or equal to 90 percent, then the reproducibility for that constituent is considered acceptable. If the percentage is less than 90 percent for a constituent, then the results for that constituent are investigated.

The reliability for a constituent is considered acceptable if the pooled relative standard deviation for that constituent is less than 14 percent. If the pooled relative standard deviation is greater than or equal to 14 percent for a constituent, then the results for that constituent will be investigated.

An example of an investigation into variability results is if variability for a constituent does not meet the criteria for acceptable reproducibility or reliability because of small constituent concentrations (relative to instrument detection levels). Variability is known to increase as concentration decreases, and the criteria for acceptable variability are not intended to apply to small concentrations.

Contamination bias, rather than instrument background uncertainty (sometimes referred to as "noise"), is considered present in a blank (and potentially a water-quality sample) when a detectable concentration of a constituent is measured from a blank. This corresponds to a concentration exceeding the reporting level of $3 s$ (app. 4) for radiochemical constituents and the reporting level for inorganic and organic constituents (tables 3-6). If a constituent is detected in a blank, then the results for that constituent are investigated. 


\section{Appendix 7. Inventory of Water-Quality and Water Level Field Equipment}

Table 7.1. Inventory of water-quality and water level field equipment.

\begin{tabular}{|c|c|c|c|}
\hline Type of meter & Model & Manufacturer & Serial number \\
\hline Multi-parameter & Quanta & Hydrolab & QD01427/QT02017 \\
\hline Multi-parameter & Quanta & Hydrolab & QD02191/QT02018 \\
\hline Multi-parameter & Quanta & Hydrolab & QD02194/QT01467 \\
\hline Multi-parameter & Quanta & Hydrolab & QD03469/QT05153 \\
\hline $\mathrm{pH}$ & Orion 3 Star & Thermo Scientific & A16054 \\
\hline Turbidity & $2100 \mathrm{P}$ & Hach & 971200016277 \\
\hline Conductivity & 122 & Orion & 0905040 \\
\hline Digital thermometer & $\begin{array}{l}\text { Traceable Memory } \\
\text { Data-log } 50\end{array}$ & Fisher Scientific & 61733096 \\
\hline Digital thermometer & $\begin{array}{l}\text { Traceable Memory } \\
\text { Data-log } 50\end{array}$ & Fisher Scientific & 72068284 \\
\hline Digital thermometer & $\begin{array}{l}\text { Traceable Memory } \\
\text { Data-log } 50\end{array}$ & Fisher Scientific & 80320036 \\
\hline Digital thermometer & $\begin{array}{l}\text { Traceable Memory } \\
\text { Data-log } 50\end{array}$ & Fisher Scientific & 101476820 \\
\hline E-tape-1 & $\begin{array}{l}\text { Water level Indicator- } \\
1,00 \mathrm{oft}\end{array}$ & $\begin{array}{l}\text { Durham Geo Slope } \\
\text { Indicator }\end{array}$ & 38303 \\
\hline E-tape-2 & $\begin{array}{l}\text { Water level Indicator - } \\
1,000 \mathrm{ft}\end{array}$ & $\begin{array}{l}\text { Durham Geo Slope } \\
\text { Indicator }\end{array}$ & 1437380 \\
\hline E-tape-3 & $\begin{array}{l}\text { Water level Indicator - } \\
1,000 \mathrm{ft}\end{array}$ & $\begin{array}{l}\text { Durham Geo Slope } \\
\text { Indicator }\end{array}$ & 36592 \\
\hline E-tape-4 & $\begin{array}{l}\text { Water level Indicator - } \\
700 \mathrm{ft}\end{array}$ & $\begin{array}{l}\text { Durham Geo Slope } \\
\text { Indicator }\end{array}$ & 1437381 \\
\hline E-tape-5 & $\begin{array}{l}\text { Water level Indicator - } \\
1,250 \mathrm{ft}\end{array}$ & $\begin{array}{l}\text { Durham Geo Slope } \\
\text { Indicator }\end{array}$ & 36529 \\
\hline E-tape- 6 & $\begin{array}{l}\text { Water level Indicator - } \\
1,000 \mathrm{ft}\end{array}$ & $\begin{array}{l}\text { Durham Geo Slope } \\
\text { Indicator }\end{array}$ & 1637401 \\
\hline Stainless steel tape & Calibration tape $-800 \mathrm{ft}$ & Cooper Tools & Not applicable \\
\hline Stainless steel tape & Calibration tape $-1,000 \mathrm{ft}$ & Cooper Tools & Not applicable \\
\hline Stainless steel tape & Calibration tape $-1,200 \mathrm{ft}$ & Cooper Tools & Not applicable \\
\hline
\end{tabular}




\title{
Appendix 8. Auditor's Checklist for Quality Assurance Field Audits
}

\author{
QUALITY-ASSURANCE FIELD AUDITS \\ AUDITOR'S CHECKLIST
}

Auditor's name

1. Date Sampler's name Site name

2. Vehicle:

Was the vehicle clean and well maintained?

Was the vehicle well stocked?

Were the field computer and printer working properly?
Yes / No
Yes / No
Yes / No

3. Site Inspection? Yes / No Details

4. Water-level measurement? Yes / No

Electric tape

Depth 1 below MP

Recorded on WL trip sheet

Tape correction 1

and laptop computer? Yes / No

Depth 2 below MP

Tape correction 2

MP

5. Portable discharge lines rinsed with DI water? Yes / No

6. Generator:

Grounded?

Parked downwind from well?

7. Time pump started?

$$
\begin{aligned}
& \text { Yes / No } \\
& \text { Yes / No }
\end{aligned}
$$

Discharge measured? Yes / No $Q=$ Purge time calculated? Yes / No $\mathrm{T}=$ Yes / No

\section{Field safety equipment:}

$\begin{array}{lclc}\text { Shovel? } & \text { Yes / No } & \text { Site-safety plan? } & \text { Yes / No } \\ \text { Bucket? } & \text { Yes / No } & \text { QA plan? } & \text { Yes / No } \\ \text { First-aid kit? } & \text { Yes / No } & \text { Body-fluids kit? } & \text { Yes / No } \\ \text { Fire extinguisher? } & \text { Yes / No } & \text { Safety vest (if required)? } & \text { Yes / No } \\ \text { Eye-wash kit? } & \text { Yes / No } & \text { Cell phone? } & \text { Yes / No } \\ \text { Hearing protection? } & \text { Yes / No } & \text { Jumper cables and ice scrapper? } & \text { Yes / No }\end{array}$


9. Constituents?

Number of bottles and designations

10. Calibrations:

Specific conductance? Yes / No

$\mathrm{pH}$ ? Yes / No

DO? Yes / No

Recorded in logbook? Yes / No

Other? Yes / No

Specify

\section{Field Measurements:}

Temperature, water? Yes / No

Value $=$

Temperature, air?

Yes / No

Value $=$

Specific conductance?

Yes / No

Value $=$

$\mathrm{pH}$ ?

Yes $/$ No $\quad$ Value $=$

DO?

Yes / No

Value $=$

Other (Specify)?

Yes $/$ No $\quad$ Value $=$

\section{Sample Collection:}

Time started

Gloves

Yes / No

Filter rinsed with DI and sample water?

Yes / No

Air purged from filter?

Yes / No

Bottles rinsed with sample if appropriate?

Yes / No

Order of filling bottles? Correct Incorrect

List

Number of rinses?

List

\section{Preservation:}

Safety equipment?

Eye shielding? Yes / No

Rubber apron? $\quad$ Yes / No

Protective gloves? Yes / No

Correct preservatives added? Yes / No

Was the correct order followed? Yes / No

\section{Sample Handling:}

Were sample bottles properly sealed?

Yes / No

Were sample bottles properly labeled?

Yes / No 
Were sample bottles properly stored?

Was proper security of sample bottles maintained?
Yes / No

Yes / No

\section{Decontamination:}

Were portable discharge lines rinsed with DI water prior to storage? Yes / No

\section{Site Clean-up and Security:}

Was the well properly secured after sampling?

Yes / No

Was the Site properly cleaned prior to departure?

$$
\text { Yes / No }
$$

\section{Paperwork copies?}

Requested? Delivered?

Field observation worksheet?

Yes / No Yes / No

Analytical service request form?

Yes / No Yes / No

Water-level trip sheet?

Yes / No Yes / No

SVMobile site visit notes?

Yes / No Yes / No

Calibration logbook sheets?

Yes / No Yes / No

PCFF field form?

Yes / No Yes / No

Other? (Specify

Yes / No Yes / No

\section{Comments:}




\section{Appendix 9. Emails Listing the Decision Process for Calibration of Tapes Decision}

On Thu, Aug 2, 2018 at 10:38 AM Bartholomay, Roy<rcbarth@usgs.gov> wrote:

Lets just apply our current calibrations to our recent records. We can do a batch correction later on if we want to incorporate the HIF steel tape calibration correction.

On Thu, Aug 2, 2018 at 10:29 AM, AmyWehnke<ajwehnke@usgs.gov>wrote:

Thanks Roy.

I agree as long as we document this, as it is a requirement that we send our tapes to HIF and use HIF calibrations. I do not plan to send any other etapes in at this time and HIF is aware of this, although I am requested to. I will continue to send the steel tapes in as required and hesitantly agree we should start applying the HIF steel tape correct to our calibration procedures. Although I did not do so in July as we wanted to keep procedures the same as past years for study reasons. If you would like me to go back and apply the steel tape correction to July, please let me know soon as I would have to correct July and Aug WL's. Are current HIF calibration for the steel tape would be $0-0.05$ ? Just a thought, do we want to start applying the HIF steel tape calibration correction to our etape calibration procedures before HIF works out any other calibration concerns? I have only focused on the etape issues, and not certain that they have the steel tape calibration procedure finalized.

On Thu, Aug 2, 2018 at 9:03 AM Bartholomay, Roy<rcbarth@usgs.gov>wrote:

My thought remains to use our calibrations to our steel tapes as we have done in the past; I could see incorporating the additional step of applying HIF calibration to our steel tape as our 0 point versus saying our steel tape is the true measurement. That is the only change I would consider for our program for now.

On Thu, Aug 2, 2018 at 11:04 AM Amy Wehnke<ajwehnke@usgs.gov>wrote:

Thanks Phil, I do agree.

Brandy as far as your original email, I do agree tapes will have a negative correction because they are not hanging straight in the well. My concern is HIF's method for calibrating etapes with tension for a straight tape does not replicate how the tape hangs in the field down hole. And, I also agree with Phil that HIF calibrations should not be used if there is a significant difference, rather try to improve the calibration procedures.

On Thu, Aug 2, 2018 at 9:34 AM Gardner, Philip < pgardner@usgs.gov> wrote:

Hi Amy-

We perform out field (down-hole) calibrations using a NIST-certified steel tape rather than a HIF-calibrated steel tape. We have various types of e-tapes RST, Waterline, Solinst, WLI, etc. In general, all of the flat tapes with the wires running down either side behave like you see in the examples I sent. And nearly all of our tapes are of that style. (round tapes of different material like WLIs behave differently and I have other reasons for not liking those but that's getting off topic).

I understand that our e-tapes will have negative corrections because they are not hanging straight in the well. And, since this represents actual field conditions, it doesn't seem like we should be using HIF calibrations that are significantly different. The thing that puzzles me is why so many HIF calibrations result in this increasingly negative correction that is of larger magnitude that ours. HIF pulls force on the E-tapes to straighten them. As I understand it they calculate and "in-use" tension that increases as they move down the tape to represent the 
increased weight that results from longer sections of tape hanging in a well. Whether this tension is representative enough of field conditions or not, it still seems that they should be straightening the tape compared to how it would hang in a well, which should result in less of a negative correction, right?

On Thu, Aug 2, 2018 at 6:20 AM,AmyWehnke<ajwehnke@usgs.gov>wrote:

Thanks Phil

There are similarities in our field calibrations compared to HIF and the increasing negative correction is very concerning from 500-1000 ft. What type of etapes are you using? Are you calibrating to a steel tape that was calibrated at HIF? If the difference is that the etapes are not hanging straight in a well, as Brandy stated, then that needs to be considered in the HIF calibration methods or changed from table calibration to hanging or down hole calibration methods. If conditions very from WSC because of field conditions (well depth, temp, condensation, deviation, casing material, etc) then maybe there is not one standard lab method of calibration, rather standardize field calibration methods. If HIF steel tape calibrations are acceptable (as ours was) maybe USGS protocol should be to calibrate etapes in the field to HIF calibrated steel tape, where the steel tape is for calibration use only.

On Wed, Aug 1, 2018 at 4:15 PM Gardner, Philip <pgardner@usgs.gov>wrote:

Hi Amy-

I'm attaching a pdf showing this same behavior / comparison between HIF calibrations and our own "down-well" field calibrations. You can see the increasing negative correction that is derived from nearly all HIF calibrators the NV e-tapes have undergone (these tapes have been to HIF twice. You can also see the year to year variability in the results of our own calibrations. We've concluded that the actual uncertainty resulting from all things considered (tapes not hanging straight, temperature effects, friction / condensation in the well, etc. etc. etc.) is on the order of $+/-0.05 \mathrm{ft}$ for the first few hundred feet. But...we are still puzzling at the increasing cumulative negative correction that results from the HIF calibration.

I understand the HIF protocols are intended to replicate "in-use" weight on the tape but there is clearly something going on that results in HIF corrections not representing field conditions. Note that this figure only shows four wells, but I can show you many more that look the same.

OnWed, Aug 1, 2018 at 3:36 PM, AmyWehnke<ajwehnke@usgs.gov>wrote:

INL thoughts please...

I am having a hard time with Brandy's thinking on the "straight tape" or the HIF reference is straight and will always read as a shorter distance to water than the field reference tape. There straight tape is never used to measure WL so how can it read a shorter distance. It is for calibration only and when they calibrate the steel tape and the etape they are both straight. So, if we compare an etape to the calibrated steel tape in the field, wouldn't the field correction for the etape be appropriate to use?

On Wed, Aug 1, 2018 at 3:05 PM Brandy Armstrong < barmstrong@usgs.gov> wrote: Amy I think you missed the point I was trying to make with my theoretical illustration. What causes the calibration correction of the field tape at HIF to be more negative than a calibration in the field is the larger negative difference between the field tape and the reference.

The HIF reference tape will always be straight and if it was calibrated against itself the correction would be zero. The well reference tape will always not be completely straight (reading slightly longer distance to water), and if calibrated against the HIF reference tape the correction would be negative. The tape being calibrated will have a different correction dependent on which 
reference tape is being used, and that is what causes the HIF calibration to always result in a larger negative correction (because the reference is straight and will always read as a shorter distance to water than the field reference tape) than in the field (where the reference is not straight and will always read at a longer distance to water than the HIF tape). As you said during a field calibration the reference could be affected by frictional forces or get caught up which would cause it to hang less straight and read even longer. The longer the reference tape reads from the true length, the smaller the negative correction would be for the field tape (assuming it was not also hung up) and if the reference tape got caught up and read particularly long, then you might even have a positive correction. This will never happen to the HIF tape since the calibration is performed on a flat on the table. The only way the field reference could then result in a correction that was more negative than the HIF reference correction is if the field reference was somehow stretched. For a tape where there is a positive correction, the HIF reference tape correction would still be less than an in well field reference correction, but on the positive side.

That is frustrating about the weights giving inconclusive results. It looks like in 3 out of 4 wells the large weight resulted in a smaller negative or positive correction when compared to no weight or a small weight. If you are comparing an electric tape with a weight attached to a steel tape without a weight attached, how do you account for the displacement of the water by the weight attached to the electric tape? Or are you also attaching the weights to the steel tape?

On Wed, Aug 1, 2018 at 2:32 PM AmyWehnke <ajwehnke@usgs.gov>wrote:

Brandy

I agree in theory that "three tapes hanging down a well and one is perfectly straight (I am sure this is impossible) one is just slightly waved, and one is bent, the bent tape is going to have the largest negative correction".

Although the bent tape represents the path the tape takes down hole (friction and deviation), the same path as the steel tape we calibrate with (friction may very between the to tapes due to material). If the etape is hanging or not as straight as the steel tape due to friction, it would have a larger negative correction. The straight tape represents HIF calibration methods which would be a smaller negative correction, not a larger negative. Which is just the opposite of our calibration results.

To add pain to misery, during our last calibration we added two different weights to the etape on wells greater than $500 \mathrm{ft}$ to see how it would affect the calibration. I expected the correction to be a smaller negative, rather the results are sporadic. We also collected air temp and barometric pressure, which I do not expect to have great effect on the calibration.

I have attached etape 1 calibration file for 2017 and 2018 INL calibration

with HIF calibration, including the INL weight test and a separate tab showing air temp and barometric pressure.

Knowing the HIF calibration for INL $1000 \mathrm{ft}$ steel tape was good with a range of 0.00 to 0.05 for a $1000 \mathrm{ft}$ tape, makes me believe calibrating our etapes to the HIF calibrated steel tape in the field is the best method of calibration as it replicates the field condition they are used.

I would be interested in anyone else's take on this.....

On Wed, Aug 1, 2018 at 1:08 PM, Sheets, Rodney<rasheets@usgs.gov>wrote:

See Idaho's in-well tape calibration results. If you have any input, I'm sure Amy (and I) would like to hear it. Doesn't really look like your in-well deep tape calibrations much.

On Tue, Jul 31, 2018 at 10:12 AM Brandy Armstrong < barmstrong@usgs.gov> wrote:

I was working on my presentation for RWDTC and had a thought. If you have three tapes hanging down a well and one is perfectly straight (I am sure this is impossible) one is just 
slightly waved and one is bent, the bent tape is going to have the largest negative correction when compared with the perfectly straight tape. So if the HIF tape table NIST reference tape represents the perfectly straight tape, it makes sense that the negative corrections on a bent tape would be larger at the HIF than they would be down a well even when compared with a very straight tape, since when hanging down a well it could never be perfectly straight like the tape on the HIF calibration table. I made a little illustration, exaggerated for the sake of making it easy to see (left panel represents HIF, middle represents down well calibration).

Along the same vein, if you were using a correction for a steel tape that had been calibrated at $10 \mathrm{lbs}$ tension, and then using that steel tape as the reference for an in well calibration of the electric tape, where the steel tape is now being used at in-use tension, then the steel tape is likely to have a different correction (slightly less/more negative) in the well than it did on the table, and contribute to the difference between a calibration of an electric tape at HIF compared with a calibration of an electric tape in the field.

I think this could explain why the HIF calibration shows a LARGER negative correction than the field calibration, and it is particularly noticeable on this tape because of the poor quality in the spacing on the markings of the tape. We have yet to run across another one like it.

I was thinking about including this in my talk at RWDTC. Please let me know if you think this is a plausible explanation for what happened with regards to this tape.

On Thu, Oct 19, 2017 at 10:52 AM Wehnke,Amy<ajwehnke@usgs.gov>wrote:

Brandy, I do not have a problem with you holding on to the tapes. Will HIF be checking just the etape or the steel tape also? I would be curious how the calibrations with bearings differ.

Yes, our calibration is showing a greater stretch at deeper depths compared to HIF. Which would not be temperature as ours temps are cooler down hole (compared to HIF temp), ours should be contracting due to temp, not stretching more.

As far as the twisting that I was seeing on our tapes after HIF calibration, it was mainly the first $30 \mathrm{ft}$ of the tape and mostly near the probe (more concerned about the tension between probe and tape when stretched).

The etape and calibration steel tape take the same path down hole, regardless of deviation or well construction. Our steel tape calibration (HIF) was - .05 at $1000 \mathrm{ft}$ and our etape differs 1.12 from down hole calibration and HIF calibration. Have had similar differences with field calibration and HIF calibration on other $1000 \mathrm{ft}$ etapes?

Please keep me posted.

On Wed, Oct 18, 2017 at 1:06 PM, Armstrong, Brandy < barmstrong@usgs.gov> wrote:

They did recalibrate your $1000 \mathrm{ft}$ tape and afterwards we decided it would be good to do a repeatability study on the electric tapes (the previous study was done on steel tapes) using some of the sample tapes we had in the QC room. So, we were holding onto it while we did the study, but it is taking longer than we thought. We have finished the two calibrations on your etape and can send it back if you need it.

Attached are the two calibrations for your etape copied into the original excel sheet that you sent me. Our two calibrations agree fairly well, but there is a difference that builds up the further we get down the tape. I had originally thought maybe this was stretching (especially since you had made the comment about the twisting and the tapes might be stretching at the data conference), but I was thinking about it backwards. It is actually showing that the second measurement was shorter, not longer. We think this has to do with the friction on the table and Blu is installing some bearings to help reduce the friction on the table. If you want to leave the 
tape with us, we can calibrate it again after the bearings are put in. If you need it back, just let me know and I will have them send it back to you.

Let me know if you have additional questions.

On Tue, Sep 26, 2017 at 8:38 AM, Armstrong, Brandy < barmstrong@usgs.gov>wrote:

We will calibrate the electric tape one more time. Right now, the temperatures have been in the upper 80's and the lab is not temperature controlled, so it is likely close to that in the lab.

On Mon, Sep 25, 2017 at 4:03 PM, Wehnke,Amy<ajwehnke@usgs.gov>wrote:

Brandy

Attached are the fielded and HIF calibration graph and calibration files. I have also included our steel tape and etape measurement used to calculate the calibration for etape- 1 .

The trend to the HIF calibration is a consistent trend, although still not following the trend to the infield calibration. Assuming HIF will re-calibrate a second time, as we discussed, please keep me posted on the results. In the meantime I am trying to make sense of the differences.

On a lighter note, I am pleased with the steel tape calibration.

If I remember correctly, calibrations are done with no temperature variable? What is the average temp condition during calibration?

On Mon, Sep 25, 2017 at 8:35 AM, Armstrong, Brandy<barmstrong@usgs.gov>wrote:

Amy and Rod,

Please find attached a pdf of the calibration tables for the two tapes, one electric and one steel. Although the steel taps is spliced at $500 \mathrm{ft}$ and the markings start over at $1 \mathrm{ft}$, in order to have the tables work correctly they entered the actual length of the tape (for instance $501 \mathrm{ft}$ instead of $1 \mathrm{ft}$ ) in order to make the software that calculates the calibration table work correctly. Unlike the previous tape, these tapes appear to be pretty consistent with the error increasing over the length of the tape. Please take a look and compare to your in-well calibrations. We are holding the tapes in the lab.

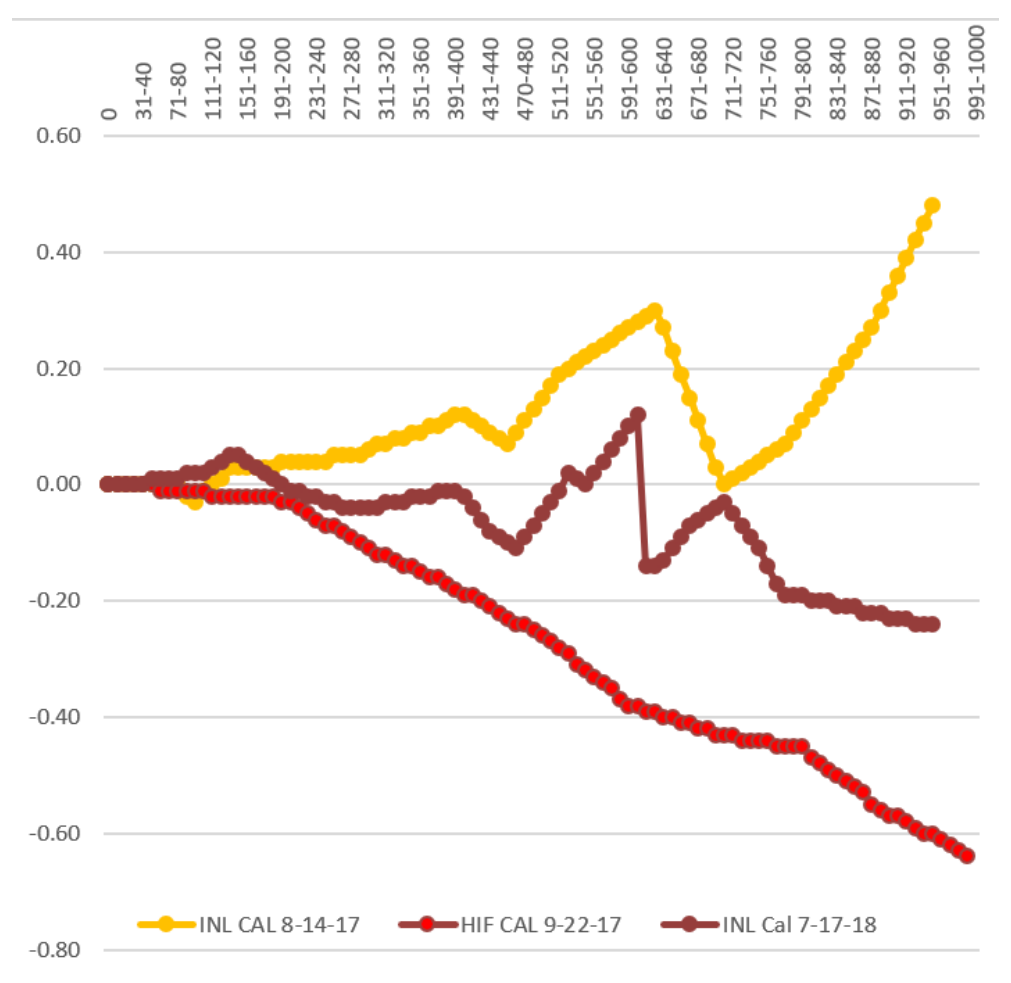


Publishing support provided by the U.S. Geological Survey Science Publishing Network, Tacoma Publishing Service Center

For more information concerning the research in this report, contact the Director, Idaho Water Science Center

U.S. Geological Survey

230 Collins $\mathrm{Rd}$

Boise, Idaho 83702-4520

https://www.usgs.gov/centers/id-water 
